\title{
Effect of Georgetown Lake on the Water Quality of Clear Creek, Georgetown, Colorado, 1997-98
}

By Sally M. Cuffin and Daniel T. Chafin

U.S. GEOLOGICAL SURVEY

Water-Resources Investigations Report 00-4109

Prepared in cooperation with the

U.S. ENVIRONMENTAL PROTECTION AGENCY

Denver, Colorado

2000 


\title{
U.S. DEPARTMENT OF THE INTERIOR BRUCE BABBITT, Secretary
}

\author{
U.S. GEOLOGICAL SURVEY
}

Charles G. Groat, Director

The use of firm, trade, and brand names in this report is for identification purposes only and does not constitute endorsement by the U.S. Geological Survey.

For additional information write to:

District Chief

U.S. Geological Survey

Box 25046, Mail Stop 415

Denver Federal Center

Denver, CO 80225-0046
Copies of this report can be purchased from:

U.S. Geological Survey Information Services

Box 25286

Federal Center

Denver, CO 80225 


\section{CONTENTS}

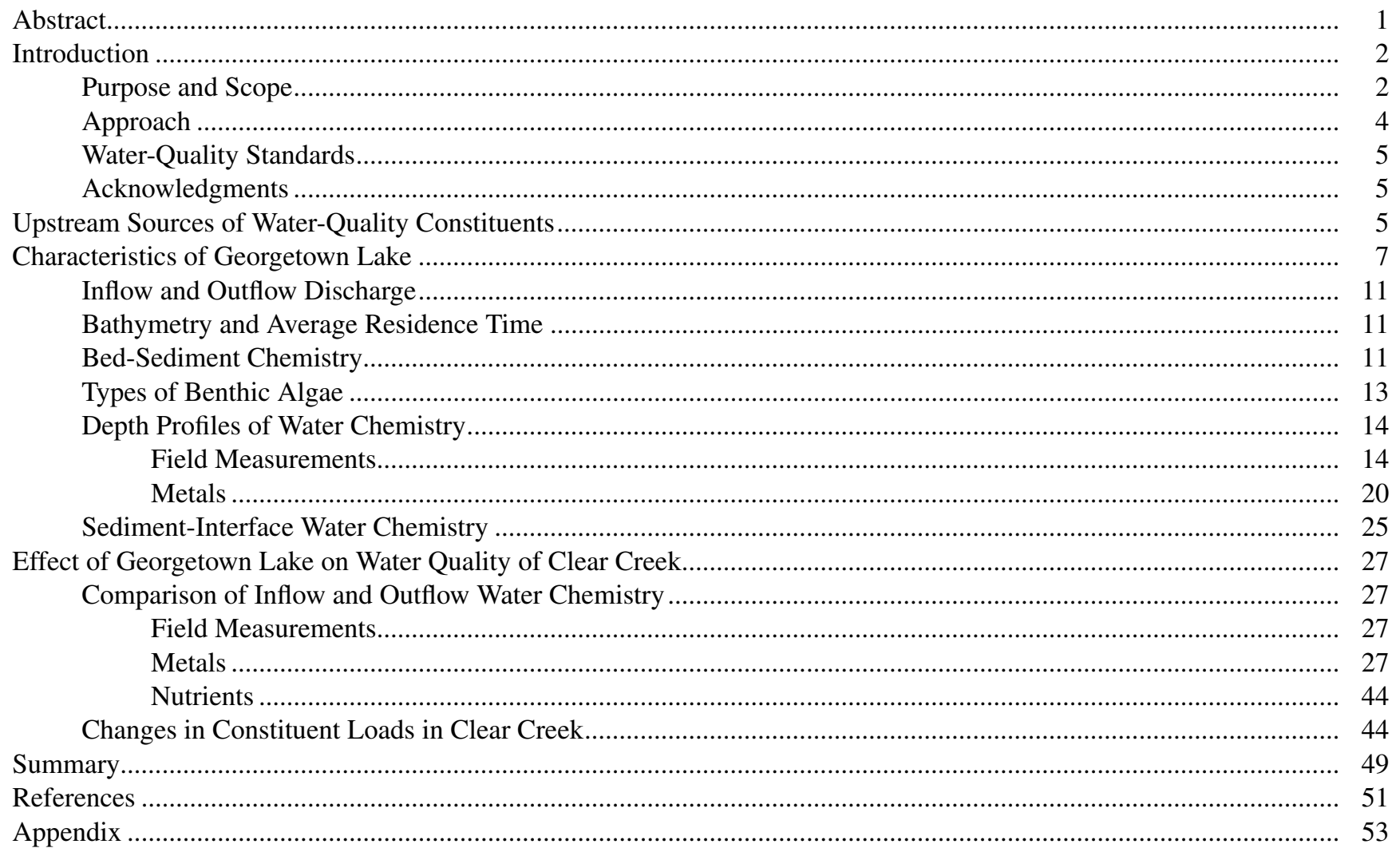

\section{PLATE}

[Plate is in pocket]

1. Map showing Georgetown Lake bathymetry, Georgetown, Colorado

\section{FIGURES}

1. Map showing Georgetown Lake study area.

2. Map showing Georgetown Lake sampling sites for streams, reservoir profiles, reservoir sediment, and sediment-interface water

3. Graph showing Georgetown Lake inflow and outflow discharge, July 1997 through September 1998

4. Graph showing estimated average residence time for Georgetown Lake

5. Map showing location of field-measurement-profile sites on Georgetown Lake, July 28, $1997 \ldots$

6. Map showing location of field-measurement-profile sites on Georgetown Lake, February 13, 1998

7-20. Graphs showing:

7. Water-temperature profiles in Georgetown Lake, July 28, 1997, and February 13, 1998

8. Specific-conductance profiles in Georgetown Lake, July 28, 1997, and February 13, 1998 .......................... 19

9. pH profiles in Georgetown Lake, July 28, 1997, and February 13, 1998_.................................................. 21

10. Dissolved-oxygen-concentration profiles in Georgetown Lake, July 28, 1997, and February 13, 1998

11. Total recoverable metal concentrations in Georgetown Lake water-quality-profile samples, March 11-12, 1998

12. Field measurements in Georgetown Lake inflow and outflow samples, 1997-98

13. Dissolved and total recoverable aluminum concentrations in Georgetown Lake inflow and outflow samples, 1997-98 
14. Dissolved and total recoverable cadmium concentrations in Georgetown Lake inflow and outflow samples, 1997-98.

15. Dissolved and total recoverable copper concentrations in Georgetown Lake inflow and outflow samples, 1997-98

16. Dissolved and total recoverable iron concentrations in Georgetown Lake inflow and outflow samples, 1997-98

17. Dissolved and total recoverable lead concentrations in Georgetown Lake inflow and outflow samples, 1997-98

18. Dissolved and total recoverable manganese concentrations in Georgetown Lake inflow and outflow samples, 1997-98

19. Dissolved and total recoverable zinc concentrations in Georgetown Lake inflow and outflow samples, 1997-98

20. Total nitrite plus nitrate and total phosphorus concentrations in Georgetown Lake inflow and outflow samples, 1997-98

\section{TABLES}

1. Water-quality data for samples collected at three sites upstream from Georgetown Lake 1997-98

2. Estimated total recoverable loads for selected metals and nitrite plus nitrate at three sites upstream from Georgetown Lake, 1997-98

3. Chemical data for reservoir-sediment samples collected from Georgetown Lake, March 23, 1998

4. Sulfate-reducing bacteria data for sediment samples collected from Georgetown Lake, March 23, 1998

5. Qualitative taxonomical identification of algae and diatoms collected from surface of Georgetown Lake sediment, 1997-98.

6. Water-quality data for reservoir-profile samples collected from Georgetown Lake, March 11-12, 1998

7. Water-quality data for sediment-interface water samples collected from Georgetown Lake, March 23, 1998

8. Water-quality data for samples collected from the Georgetown Lake inflow, site SW24U, 1997-98

9. Water-quality data for samples collected from the Georgetown Lake outflow, site SW24L, 1997-98

10. Field measurements and iron concentrations in Georgetown Lake inflow and outflow samples during a 16-hour period, September 10-11, 1998

11. Estimated total recoverable loads for selected metals and nitrite plus nitrate for Clear Creek at Georgetown Lake inflow, site SW24U, 1997-98

12. Estimated total recoverable loads for selected metals and nitrite plus nitrate for Clear Creek at Georgetown Lake outflow, site SW24L, 1997-98

13. Estimated annual total recoverable loads of selected metals and nitrite plus nitrate to and from Georgetown Lake, 1997-98.

A1. U.S. Environmental Protection Agency Region VIII Laboratory processing and analytical requirements for Georgetown Lake samples....

A2. Analytical methods used for analysis of Georgetown Lake water-quality samples......

A3. Summary of U.S. Environmental Protection Agency analytical methods used for analysis of filtered samples.

A4. Summary of U.S. Environmental Protection Agency analytical methods used for analysis of unfiltered samples.

A5. Results of water-quality analyses for duplicate total recoverable metal samples collected from Georgetown Lake inflow and outflow, 1997-98

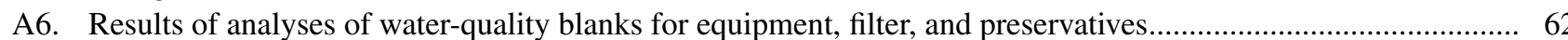

A7. Results of analyses of U.S. Geological Survey standard-reference samples 
CONVERSION FACTORS, TERMS, AND ABBREVIATIONS

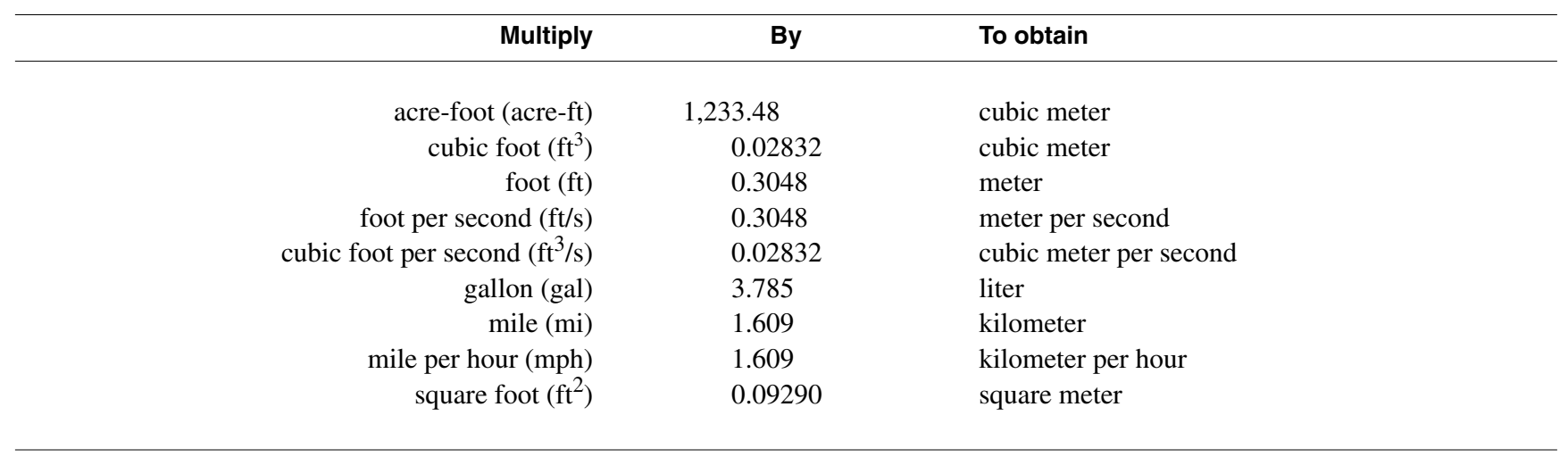

Degrees Celsius $\left({ }^{\circ} \mathrm{C}\right)$ may be converted to degrees Fahrenheit $\left({ }^{\circ} \mathrm{F}\right)$ by using the following equation:

$$
{ }^{\circ} \mathrm{F}=9 / 5\left({ }^{\circ} \mathrm{C}\right)+32
$$

The following terms and abbreviations also are used in this report:

greater than $(>)$

less than $(<)$

plus or minus $( \pm)$

parts per million ( $\mathrm{ppm})$

kilogram $(\mathrm{kg})$

kilogram per year $(\mathrm{kg} / \mathrm{yr})$

microsiemens per centimeter $(\mu \mathrm{S} / \mathrm{cm})$

micrometer $(\mu \mathrm{m})$

milligram per kilogram $(\mathrm{mg} / \mathrm{kg})$

milligram per liter $(\mathrm{mg} / \mathrm{L})$

microgram per liter $(\mu \mathrm{g} / \mathrm{L})$

Chemical Abbreviations

Aluminum (Al)

Arsenic (As)

Cadmium (Cd)

Calcium (Ca)

Calcium carbonate $\left(\mathrm{CaCO}_{3}\right)$

Carbon $(\mathrm{C})$

Carbonate $\left(\mathrm{CO}_{3}\right)$

Chloride $(\mathrm{Cl})$

Chromium (Cr)

Copper $(\mathrm{Cu})$

Fluoride (F)

Iron $(\mathrm{Fe})$

Lead $(\mathrm{Pb})$

Magnesium $(\mathrm{Mg})$

Manganese (Mn)

Nickel (Ni)

Nitric acid $\left(\mathrm{HNO}_{3}\right)$

Nitrogen $(\mathrm{N})$

Phosphorus (P)

Potassium (K)

Selenium (Se)

Silica $\left(\mathrm{SiO}_{2}\right)$

Silver (Ag)

Sulfur (S)

Sulfate $\left(\mathrm{SO}_{4}\right)$

Sulfuric acid $\left(\mathrm{H}_{2} \mathrm{SO}_{4}\right)$

Thallium (Tl)

Zinc (Zn) 


\title{
Effect of Georgetown Lake on the Water Quality of Clear Creek, Georgetown, Colorado, 1997-98
}

\author{
By Sally M. Cuffin and Daniel T. Chafin
}

\section{Abstract}

Georgetown Lake is a recreational reservoir located in the upper Clear Creek Basin, a designated Superfund site because of extensive metal mining in the past. Metals concentrations in Clear Creek increase as the stream receives runoff from mining-affected areas. In 1997, the U.S. Geological Survey, in cooperation with the U.S. Environmental Protection Agency, began a study to determine the effect of the reservoir on the transport of metals in Clear Creek.

A bathymetric survey determined the capacity of the reservoir to be about 440 acre-feet of water, which remained constant during the study. Average water residence time in the reservoir is about 1-3 days during high flow. During low flow (10 cubic feet per second), average residence is about 22 days without ice cover and about 15 days with a 3 -foot-thick ice cover.

Sediment samples collected from the bottom of Georgetown Lake contained substantial concentrations of iron (average 25,500 milligrams per kilogram), aluminum (average 12,300 milligrams per kilogram), zinc (2,830 milligrams per kilogram), lead (618 milligrams per kilogram), manganese (548 milligrams per kilogram), and sulfide minerals (average 602 milligrams per kilogram as S). Sediment also contained abundant sulfate-reducing bacteria, indicating anoxic conditions. Algae and diatoms common to cold-water lakes were identified in sediment samples; one genus of algae is known to adapt to low-light conditions such as exist beneath ice cover.
Vertical profiles of temperature, specific conductance, $\mathrm{pH}$, and dissolved-oxygen concentrations were measured in the reservoir on July 28, 1997, when inflow to the reservoir was about 170 cubic feet per second and average residence time of water was about 1.3 days, and on February 13, 1998, when the reservoir was covered with about 3 feet of ice, inflow was about 15 cubic feet per second, and average residence time was about 12 days. The measurements on July 28, 1997, showed that the reservoir water was well mixed, although $\mathrm{pH}$ and dissolvedoxygen concentrations were increased by photosynthesis near the bottom of the reservoir. Measurements on February 13, 1998, indicated thermal and chemical stratification with warmer water (about 4 degrees Celsius) beneath colder water and increases in $\mathrm{pH}$ and dissolvedoxygen concentrations generally occurring near the top of the warmer layer. Concentrations of dissolved oxygen were saturated to oversaturated throughout the water column on both dates, although the concentrations were greater on February 13, 1998, because of colder temperature and photosynthesis. Median $\mathrm{pH}$ was about 0.5 unit higher on February 13, 1998, than on July 28,1997 , largely because the longer residence time on February 13, 1998, allowed greater cumulative effects of photosynthesis.

Samples of inflow and outflow water were collected from August 1997 to August 1998. Dissolved cadmium and dissolved lead in inflow and outflow samples exceeded acute and chronic water-quality standards during some of the sampling period, whereas dissolved zinc 
exceeded both standards in inflow and outflow samples during the entire sampling period. Chromium, nickel, and silver were detected in a few samples at small concentrations. Arsenic, selenium, and thallium were not reported in any water samples.

Georgetown Lake removes some metals from inflow water and releases others to outflow water. From August 1997 to August 1998, Georgetown Lake estimated outflow loads were about 21 percent less than the inflow load of cadmium and about 11 percent less than the inflow load of zinc. Estimated inflow loads were about 18 percent less than the outflow load of copper, about 13 percent less than the outflow load of iron, and about 27 percent less than the outflow load of manganese. Inflow and outflow loads of lead were essentially balanced. The outflow load of nitrite plus nitrate was about 14 percent less than the inflow load, probably because of plant uptake.

\section{INTRODUCTION}

Georgetown Lake is a small recreational reservoir located on Clear Creek near the town of Georgetown, Colorado (fig. 1). The headwaters of Clear Creek are at the Continental Divide, from where the creek generally flows eastward, joining the South Platte River at Denver. Much of the western part of the basin was heavily mined during the late 1800's and early 1900's for gold, silver, zinc, and lead, but because of declines in metal prices and depletion of the mineral deposits, most mines were soon abandoned. The numerous abandoned mines and exposed mine tailings are a major source of metal contamination to Clear Creek and its tributaries (Wentz, 1974; Moran and Wentz, 1974).

In 1983, the Clear Creek Basin was placed on the National Priority List of Superfund Sites by the U.S. Environmental Protection Agency (USEPA) because of elevated metal concentrations in Clear Creek. The primary environmental problem associated with this Superfund site involves the effect of metal contamination on the habitat of fish and other aquatic life in Clear Creek; the creek also is an important drinking-water supply for metropolitan Denver.
The USEPA and the Colorado Department of Public Health and Environment (CDPHE) are in the process of determining the best use of Superfund resources allocated to the Clear Creek Basin. Previous water-quality sampling in the basin indicated that discharge from the Burleigh Tunnel (fig. 1) contributes roughly one-half of the metal load in Clear Creek at Silver Plume (Dana Allen, U.S. Environmental Protection Agency, written commun., 1999). A pilot wetlands treatment system was installed at the outflow of the tunnel to treat the mine drainage, but after the first year of operation, metal-removal efficiencies were not sufficient to permanently adopt that treatment. Also, the Burleigh Tunnel is not the only source of metal loads in upper Clear Creek. Additional data (Dana Allen, U.S. Environmental Protection Agency, written commun., 1999) indicated that Georgetown Lake (fig. 1) could be acting as a source or sink for some metals of concern.

Because the effects of Georgetown Lake on metal concentrations in Clear Creek were not clearly known and the effects needed to be assessed to design a different remedial action at the Burleigh Tunnel, the U.S. Geological Survey (USGS), in cooperation with the USEPA, began a year-long study in July 1997 to quantify the effects of Georgetown Lake on the fate and transport of metals in upper Clear Creek. Specific objectives of the study were the following:

1. Estimate relative contributions of metals and nutrients to Georgetown Lake by upstream tributaries;

2. Characterize bathymetry, average residence time of water, and hydrochemistry of Georgetown Lake; and

3. Determine changes in the water quality of Clear Creek caused by Georgetown Lake.

\section{Purpose and Scope}

This report provides estimates of relative loads of commonly detected metals and nitrite plus nitrate contributed by the main stem of Clear Creek and two tributary streams directly upstream from Georgetown Lake. The characteristics of Georgetown Lake are described with respect to bathymetry and average residence time as a function of discharge. Data for metal content and population of sulfate-reducing bacteria for reservoir-sediment samples are presented, and a qualitative taxonomical identification of algae and diatoms in Georgetown Lake is given. Depth profiles 


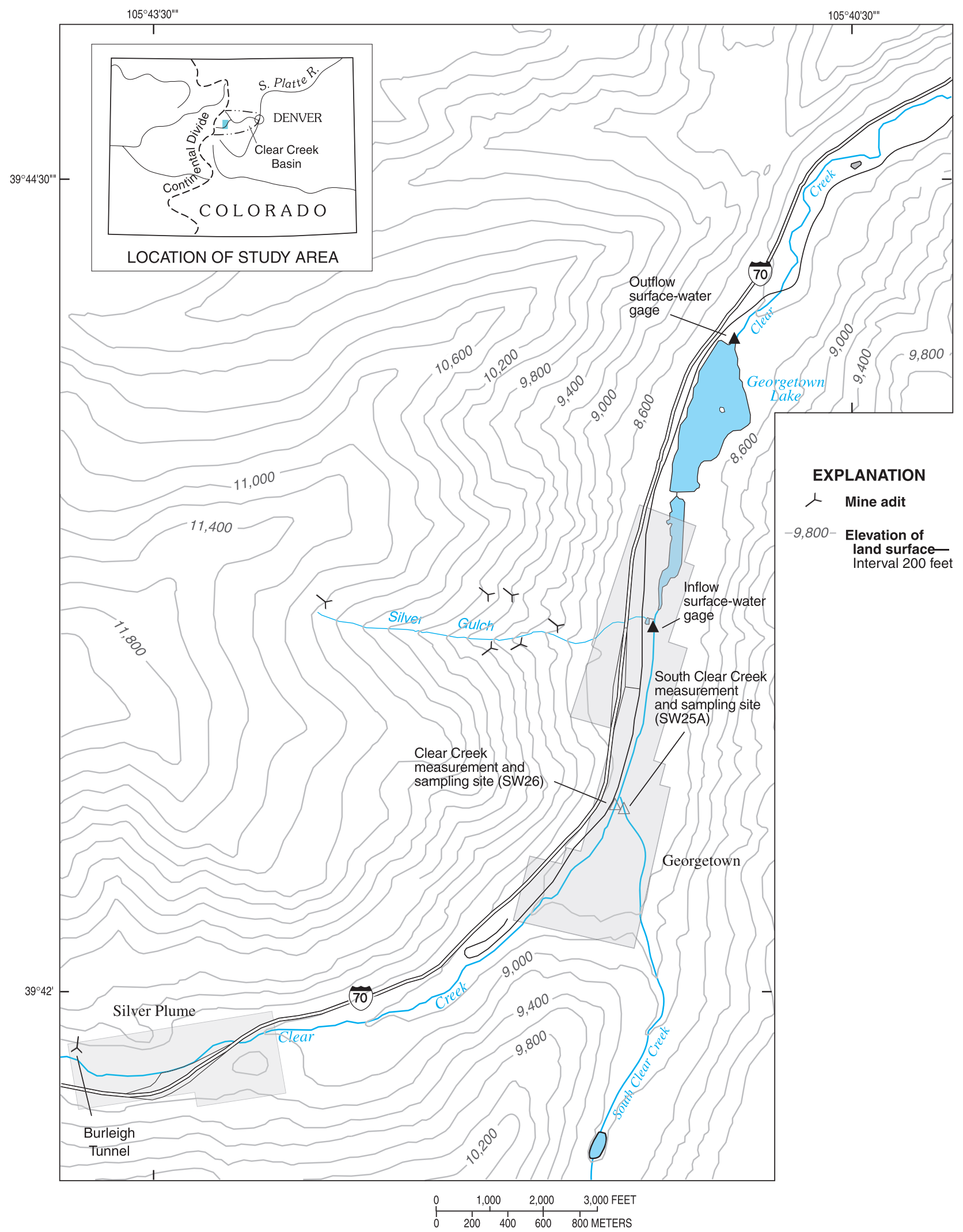

Figure 1. Georgetown Lake study area. 
of reservoir-water chemistry are described for temperature, specific conductance, $\mathrm{pH}$, concentrations of dissolved oxygen, and concentrations of metals of concern. Water-quality data for sediment-interface water are presented and described. The effect of Georgetown Lake on the water quality of Clear Creek is evaluated by a comparison of the chemistry (especially metal concentrations) of inflow and outflow water from August 1997 to August 1998. Metal concentrations are compared to Colorado waterquality standards. The effects of Georgetown Lake on loads of pertinent metals and nitrite plus nitrate are quantified.

\section{Approach}

This section presents an overview of datacollection activities and analysis. Specific datacollection and interpretive methods are described in subsequent sections. To determine upstream sources of water-quality constituents to Georgetown Lake, water-quality samples were collected and discharge was measured upstream from the reservoir inflow at the mouths of two tributary creeks and at the main stem of Clear Creek upstream from the two creeks. Discharge into and out of the reservoir was measured using continuously recording streamflow gages installed upstream and downstream from the reservoir. Because the capacity of the reservoir was unknown at the beginning of the study, a bathymetric survey was done to characterize reservoir-bottom topography and determine reservoir capacity, which was used to calculate the average residence time. Six reservoirsediment samples were collected and analyzed for concentrations of metals and sulfides. Four of these samples were analyzed for populations of sulfatereducing bacteria, and two were analyzed for qualitative taxonomical identification of algae and diatoms. Field-measurement depth profiles were made during summer and winter to determine if the reservoir was stratified. Water-quality samples were collected at various depths at six sites during late winter to characterize the distribution of water-quality constituents, especially metals, areally and vertically in the reservoir. Concentrations of metals and other constituents upstream and downstream from the reservoir were determined by collecting surface-waterquality samples from the inflow and outflow over a 1-year period. Discharge data and total recoverable concentrations of commonly detected metals and nitrite plus nitrate were used to estimate annual loads for inflow and outflow, and the differences in loads were used to estimate the net effect of Georgetown Lake on outflow loads.

Field measurements for water-quality samples and reservoir profiles consisted of temperature, specific conductance, $\mathrm{pH}$, and concentration of dissolved oxygen. Water-quality samples collected for this study were analyzed for alkalinity, major cations and anions, silica, dissolved and total recoverable metals, total nutrients (ammonia, nitrite plus nitrate, phosphorus), dissolved and total organic carbon, and total suspended solids. Samples for dissolved, inorganic constituents were filtered through a $0.45-\mu \mathrm{m}$, glass-fiber filter. All water-quality samples were collected using the USGS parts-per-billion protocol (Horowitz and others, 1994).

The USEPA Region VIII Laboratory processing and analytical requirements used for the Georgetown Lake samples are provided in table A1 (Appendix). Samples were analyzed by three laboratories: the USEPA Region VIII Laboratory (samples collected from August 14, 1997, through March 23, 1998); the Bureau of Reclamation Environmental Research Chemistry Laboratory (samples collected on April 13, 1998); and Accu-Labs Research, Inc., a commercial laboratory under contract to the USEPA (samples collected on April 1, 1998, and from April 27, 1998, through August 10, 1998). Changing laboratories during the study resulted in changing analytical methods for a number of constituents. The analytical methods are described in table A2 (Appendix). Methods used for analysis of filtered samples are summarized in table A3 (Appendix), and methods used for analysis of unfiltered samples are summarized in table A4 (Appendix).

Thirty-three duplicate samples and 32 sets of blanks were collected with inflow and outflow water-quality samples. Concentrations of total recoverable metals in duplicate samples are listed in table A5 (Appendix). Total recoverable concentrations of selected metals and phosphorus in blank water exposed to sampling equipment and filters and treated with preservative solutions are listed in table A6 (Appendix). Two sets of USGS standard-reference samples (Farrar and Long, 1996) were analyzed by Accu-Labs Research, Inc., during the study. The reference samples provided to the laboratory included a trace-constituent sample (T-141) and a major-constituent sample (M-138). Results for analyses of these standard-reference samples are listed in table A7 (Appendix). 


\section{Water-Quality Standards}

The CDPHE Water Quality Control Commission promulgates regulations that establish classification and numeric water-quality standards for streams in Colorado, including Clear Creek. The classifications for upper Clear Creek, including Georgetown Lake, are class 1, coldwater aquatic life; class 1 , recreational; and agricultural. The class 1 , cold-water aquatic life classification indicates that these waters are currently capable of sustaining a wide variety of cold-water biota or could sustain such biota if water-quality conditions were corrected. Class 1 recreation indicates that these waters are suitable or intended to become suitable for recreational activities in or on the water when the ingestion of small quantities of water is likely to occur (activities such as swimming, rafting, kayaking, and waterskiing). The agricultural classification indicates that these waters are suitable or intended to be suitable for irrigation of crops commonly grown in Colorado and are not hazardous as drinking water for livestock (Colorado Department of Public Health and Environment, 1999a).

Water-quality standards for aquatic life are specified by the CDPHE Water Quality Control Commission. Regulations for Clear Creek come from the Classifications and Numeric Standards for the South Platte River Basin (Colorado Department of Public Health and Environment, 1999b). Georgetown Lake is located in segment 2 of the Clear Creek Basin.

Many water-quality standards (acute and chronic) for metals have hardness (the sum of $\mathrm{Ca}^{2+}$ and $\mathrm{Mg}^{2+}$ equivalents per liter, expressed as milligrams per liter as $\mathrm{CaCO}_{3}$ ) as one of the variables used to calculate them. The standards generally apply only to dissolved metal concentrations. Increased hardness normally reduces metal toxicity by increasing competition with metals for sorption sites, reducing the bioavailability of metals to aquatic life. The hardness concentration for each sample was applied to the appropriate Table Value Standards (TVS) equations for acute and chronic standards to determine the metals standard for that sample. The acute standard applies to the concentration in a single sample or average of samples collected over a 1-day period, whereas the chronic standard applies to a single sample or average of samples collected over a 30-day period (Colorado Department of Public Health and Environment, 1999b).

\section{Acknowledgments}

The authors thank the following people who made completion of this study possible. The city officials of Georgetown allowed the installation of the surface-water gages near the reservoir. Officials from the Colorado Division of Wildlife provided important historical data about the site. William Wilson, a citizen of Georgetown, provided weather information for the Georgetown area that was used in this report. Ronald Ferrari and Kent Collins (Bureau of Reclamation, Sedimentation and River Hydraulics Group) fought high winds to perform the bathymetric survey of the lake. William Schroeder (USEPA) surveyed the reservoir shoreline, providing necessary information to complete the bathymetric survey. Kathy Hernandez (USEPA) provided important information about and assisted with the assembly and preparation of sediment-interface water sampling apparatus. The authors also appreciate the data-collection efforts of personnel from the Lakewood Field Office of the USGS.

\section{UPSTREAM SOURCES OF WATER- QUALITY CONSTITUENTS}

To characterize upstream sources of waterquality constituents to Georgetown Lake, waterquality samples were collected from: (1) South Clear Creek upstream from the confluence with Clear Creek, site SW25A (fig. 1); (2) the main stem of Clear Creek upstream from the confluence with South Clear Creek, site SW26 (fig. 1); and (3) Silver Gulch, site SW24SG (fig. 2), a small tributary that discharges into Clear Creek about $300 \mathrm{ft}$ upstream from the reservoir inflow.

About midway through the study, 12 waterquality samples were collected monthly: 6 from the main stem of Clear Creek and 6 from South Clear Creek (fig. 1). Clear Creek was sampled about $100 \mathrm{ft}$ upstream from the confluence with South Clear Creek, and South Clear Creek was sampled about $100 \mathrm{ft}$ upstream from the confluence, which is about $3,600 \mathrm{ft}$ upstream from the reservoir inflow. These two sites were sampled by the equal-width-increment method (Edwards and Glysson, 1988), which provides a representative sample that is a discharge-weighted, crosssectional average of stream composition. Although mining occurred in both drainage basins, mining activities along the main stem of Clear Creek were more extensive. 


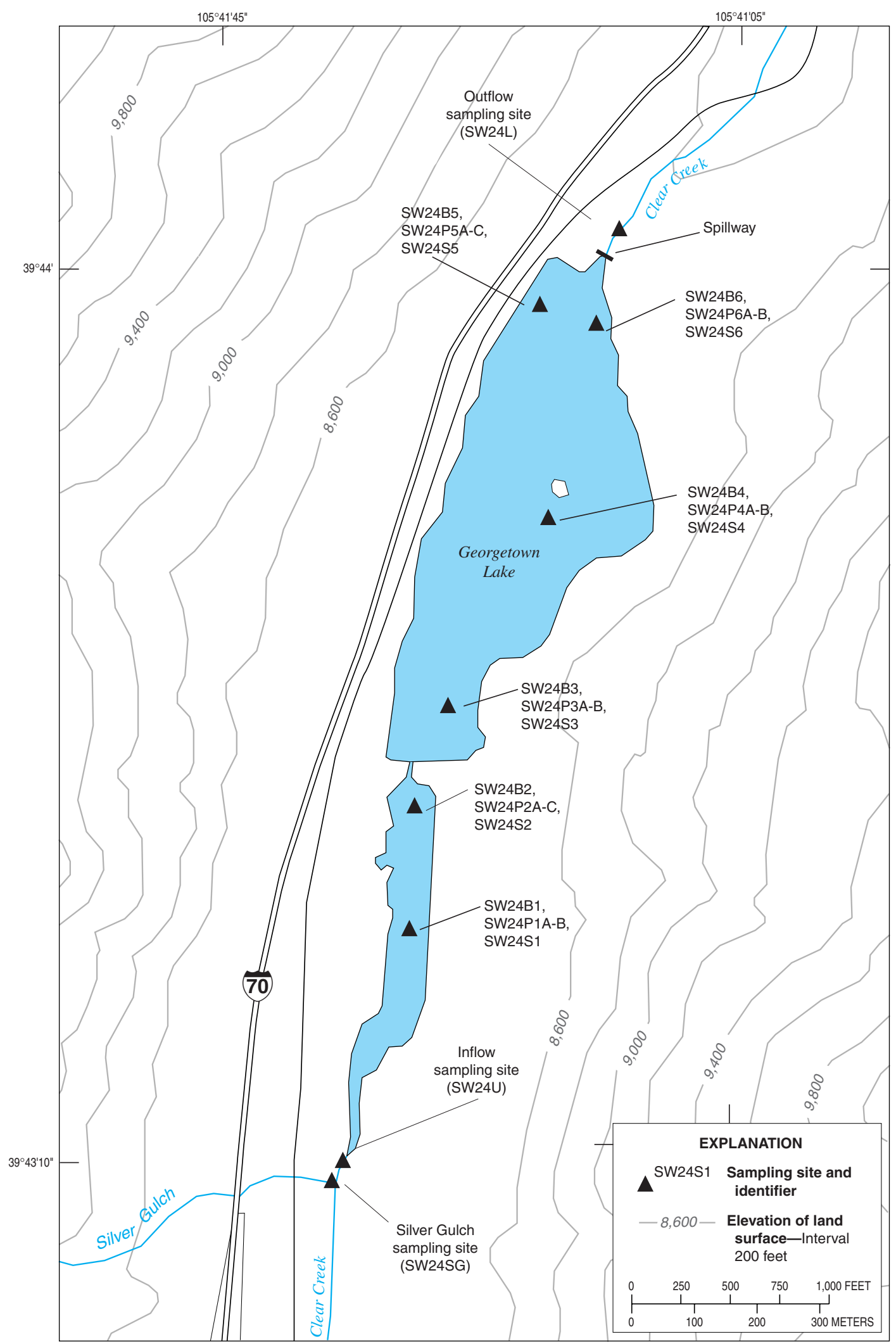

Figure 2. Georgetown Lake sampling sites for streams, reservoir profiles, reservoir sediment, and sediment-interface water. 
Five water-quality samples were collected from Silver Gulch (fig. 2). A study done in the early 1900's identified at least 13 mine sites in the Silver Gulch basin as possible sources of metals (Spurr and others, 1908). Water-quality samples were collected directly from the mouth of a corrugated-metal culvert that extends about $200 \mathrm{ft}$ under a parking lot, discharging into Clear Creek about $3 \mathrm{ft}$ above the streambed. Results of analyses of samples from all three sites are listed in table 1.

Sample results (table 1) showed higher average total recoverable concentrations of aluminum, cadmium, iron, manganese, and zinc in the main stem of Clear Creek than in South Clear Creek; the same relationship existed for dissolved concentrations of cadmium, manganese, and zinc. Concentrations of total recoverable copper and lead were similar. Total nitrite plus nitrate was present in the main stem of Clear Creek at a higher average concentration than in South Clear Creek. Although the upstream drainage basins of both streams were extensively mined, activity along the main stem of Clear Creek supplied greater metal concentrations to Georgetown Lake.

Silver Gulch samples (table 1) had substantially greater dissolved and total recoverable concentrations of cadmium, lead, and zinc than did samples from South Clear Creek and, during relatively high flow (table 2), than did the main stem of Clear Creek.

Estimated total recoverable loads (table 2) for selected metals and nitrite plus nitrate were greater in the main stem of Clear Creek than in South Clear Creek. On the six sampling dates, estimated loads for the main stem of Clear Creek exceeded estimated loads in South Clear Creek by the following factors, on average: cadmium, 16; copper, 2.3; iron, 6.0; lead, 2.8; manganese, 3.9; zinc, 14 , and nitrite plus nitrate, 5.0. A comparison of the three samples collected at each site during May, June, and August 1998 indicates that Silver Gulch contributed negligible constituent loads compared to the main stem of Clear Creek, which exceeded Silver Gulch by the following factors, on average: cadmium, 550; copper, 630; iron, 1,370; lead, 290; manganese, 3,800; zinc, 680; and nitrite plus nitrate, 5,300. Metal loads contributed to Clear Creek by Silver Gulch were not very large because discharge in Silver Gulch ranged from only about $0.02 \mathrm{ft}^{3} / \mathrm{s}$ during low flow to about $2.5 \mathrm{ft}^{3} / \mathrm{s}$ during high flow.

\section{CHARACTERISTICS OF GEORGETOWN LAKE}

Georgetown Lake (fig. 1) is divided into a large and a small pool of water, connected by a concrete bridge/culvert under a raised earthen roadway. The northern, larger pool is about 2,750 ft long and varies in width from about 400 to $1,100 \mathrm{ft}$. The southern, smaller pool is about 2,000 ft long with an average width of about $220 \mathrm{ft}$. A bathymetric survey indicated that the average depth of the larger pool is about $8 \mathrm{ft}$ with several areas that are 12 to $16 \mathrm{ft}$ deep. The smaller pool is deeper, with an average depth of about $13 \mathrm{ft}$ and areas that are 14 to $20 \mathrm{ft}$ deep. The reservoir, with a surface elevation at about $8,444 \mathrm{ft}$, is situated in a narrow valley between two northeast-trending mountain ridges with elevations of about 11,000 to $11,500 \mathrm{ft}$. Waste piles and tunnel openings from abandoned mines are visible along both sides of the valley. The reservoir is bordered by a steep slope along the eastern shoreline and by a gravel parking area and a frontage road along the western shoreline. Interstate 70 runs west of the frontage road.

The dam structure is an earth and rock-fill dam with a concrete spillway. All flow from the reservoir passes over the spillway. The reservoir can be drained using a pipeline at the bottom of the spillway structure, but this pipeline is opened only occasionally to test the control valve.

Recreational use of the lake consists primarily of shoreline fishing. Gasoline powered boats are banned from the reservoir, but electric motors are allowed. Little boat traffic is observed on the reservoir because of the high winds in the area. Winter recreational activities include ice fishing and occasional ice sailboating. Jeep races are held annually after the ice reaches sufficient thickness. On the western shore of the large pool, a bighorn sheep viewing area attracts tourists year round.

Mountain winds intensify as they move through the narrow valleys, and 40-to-50-mph peak gusts are common during the day near the reservoir (William Wilson, Georgetown resident, oral commun., 1998). The winds typically begin as the morning sun warms the surrounding peaks, strengthening throughout the day, and calming down at night. Weather systems moving through the mountains can intensify the winds at any time of the day. The winds generate waves on the reservoir, providing energy to mix the water column when the reservoir is free of ice. 
Table 1. Water-quality data for samples collected at three sites upstream from Georgetown Lake, 1997-98

[See Appendix, table A2, for the methods of analysis used for these samples; ${ }^{\circ} \mathrm{C}$, degrees Celsius; $\mu \mathrm{S} / \mathrm{cm}$, microsiemens per centimeter at $25 \mathrm{degrees}$ Celsius; $\mathrm{mg} / \mathrm{L}$, milligrams per liter; $\mu \mathrm{g} / \mathrm{L}$, micrograms per liter; <, less than; --, no data; see figures 1 and 2 for sampling-site locations]

\begin{tabular}{|c|c|c|c|c|c|c|c|c|c|c|c|c|c|c|c|c|c|c|c|c|c|c|c|c|c|c|}
\hline \multirow{2}{*}{$\begin{array}{l}\text { Sampling } \\
\text { date }\end{array}$} & \multirow{2}{*}{$\begin{array}{l}\text { Water } \\
\text { temper- } \\
\text { ature } \\
\left({ }^{\circ} \mathrm{C}\right)\end{array}$} & \multirow{2}{*}{$\begin{array}{l}\text { Specific } \\
\text { conduc- } \\
\text { tance } \\
(\mu \mathrm{S} / \mathrm{cm})\end{array}$} & \multirow{2}{*}{$\mathrm{pH}$} & \multirow{2}{*}{$\begin{array}{c}\begin{array}{c}\text { Dis- } \\
\text { solved } \\
\text { oxygen } \\
\text { (mg/L) }\end{array} \\
\end{array}$} & \multirow{2}{*}{$\begin{array}{c}\text { Alka- } \\
\text { linity } \\
\text { (mg/L as } \\
\left.\mathrm{CaCO}_{3}\right) \\
\end{array}$} & \multicolumn{4}{|c|}{$\begin{array}{l}\text { Cations } \\
\text { (mg/L) }\end{array}$} & \multicolumn{3}{|c|}{$\begin{array}{l}\text { Anions } \\
\text { (mg/L) }\end{array}$} & \multirow{2}{*}{$\begin{array}{c}\text { Silica } \\
(\mathrm{mg} / \mathrm{L} \text { as } \\
\left.\mathrm{SiO}_{2}\right)\end{array}$} & \multicolumn{13}{|c|}{$\begin{array}{c}\text { Dissolved metals } \\
(\mu \mathrm{g} / \mathrm{L})\end{array}$} \\
\hline & & & & & & $\mathrm{Ca}$ & Mg & K & $\mathrm{Na}$ & $\mathrm{Cl}$ & $\mathbf{F}$ & $\mathrm{SO}_{4}$ & & Al & As & Cd & $\mathrm{Cr}$ & $\mathrm{Cu}$ & $\mathrm{Fe}$ & $\mathrm{Pb}$ & Mn & $\mathrm{Ni}$ & Se & $\mathrm{Ag}$ & TI & Zn \\
\hline \multicolumn{27}{|c|}{ Site SW26, main stem of Clear Creek upstream from the confluence with South Clear Creek } \\
\hline 03/04/98 & 2.5 & 231 & 7.6 & 11.0 & 56 & 21 & 7.7 & $<2$ & 11 & 20.4 & 0.44 & 16 & 6.5 & $<40$ & $<50$ & 2.7 & $<4$ & $<0.8$ & 16 & $<0.8$ & 29 & $<11$ & $<40$ & $<6$ & $<50$ & 890 \\
\hline 04/01/98 & 5.0 & 261 & 8.1 & 10.3 & 60 & 25 & 8.4 & 1.2 & 15 & 43 & 0.52 & 17 & -- & $<45$ & $<1$ & 3.2 & $<5$ & $<1$ & 20 & $<1$ & 25 & $<1$ & $<5$ & $<0.1$ & $<50$ & 1,400 \\
\hline 05/04/98 & 7.0 & 221 & 7.9 & 8.6 & 48 & 20 & 6.3 & 0.9 & 14 & 40 & 0.33 & 14 & -- & $<45$ & $<1$ & 2.0 & $<5$ & $<1$ & 30 & $<1$ & 27 & $<1$ & $<5$ & $<0.1$ & $<50$ & 690 \\
\hline 06/01/98 & 8.7 & 80.6 & 7.9 & 9.0 & 26 & 8.9 & 2.5 & 0.6 & 3.3 & 6 & 0.23 & 6 & -- & 49 & $<1$ & 0.7 & $<5$ & 2 & 30 & 2 & 8 & $<1$ & $<5$ & $<0.1$ & $<50$ & 160 \\
\hline $07 / 06 / 98$ & 8.0 & 66.3 & 7.6 & 8.5 & 22 & 8.2 & 2.2 & 0.6 & 1.9 & 3 & 0.19 & 4 & -- & $<45$ & $<5$ & 0.4 & $<5$ & $<1$ & 20 & $<1$ & $<5$ & $<5$ & $<5$ & $<0.1$ & $<50$ & 120 \\
\hline 08/03/98 & 9.8 & 90.7 & 7.7 & 8.0 & 32 & 12 & 3.2 & $<0.5$ & 3.1 & 4 & 0.26 & 7 & -- & $<45$ & $<5$ & 0.5 & $<5$ & $<1$ & 40 & $<1$ & 10 & $<5$ & $<5$ & $<0.1$ & $<50$ & 190 \\
\hline \multicolumn{27}{|c|}{ Site SW25A, South Clear Creek upstream from the confluence with the main stem of Clear Creek } \\
\hline 03/04/98 & 2.0 & 124 & 8.0 & 11.2 & 45 & 15 & 4.6 & $<2$ & 1.9 & $<0.5$ & $<0.2$ & 12 & 7.0 & $<40$ & $<50$ & $<0.5$ & $<4$ & $<0.8$ & 13 & $<0.8$ & 8 & $<11$ & $<40$ & $<6$ & $<50$ & 42 \\
\hline 04/01/98 & 2.0 & 122 & 8.4 & 11.0 & 44 & 16 & 8.4 & 1.1 & 2.1 & 1.4 & 0.21 & 15 & -- & $<45$ & $<1$ & 0.1 & $<5$ & $<1$ & 20 & $<1$ & 8 & $<1$ & $<5$ & $<0.1$ & $<1$ & 60 \\
\hline 05/04/98 & 4.0 & 128 & 8.3 & 9.4 & 50 & 16 & 5.2 & 1.2 & 2.4 & 1.9 & 0.13 & 16 & -- & $<45$ & $<1$ & 0.2 & $<5$ & $<1$ & 20 & $<1$ & 8 & $<1$ & $<5$ & $<0.1$ & $<1$ & 78 \\
\hline $06 / 01 / 98$ & -- & 74 & 8.0 & 8.6 & 34 & 9.2 & 2.7 & 1.0 & 1.4 & 1.0 & 0.11 & 9 & -- & 120 & $<1$ & 0.4 & $<5$ & 5 & 160 & 5 & 37 & $<1$ & $<5$ & $<0.1$ & $<1$ & 110 \\
\hline 07/06/98 & 11.0 & 70 & 7.9 & 8.5 & 28 & 8.6 & 2.6 & 1.0 & 1.4 & 0.8 & 0.09 & 8 & -- & $<45$ & $<5$ & 0.2 & $<5$ & 1 & 20 & $<1$ & 7 & $<5$ & $<5$ & $<0.1$ & $<1$ & 62 \\
\hline 08/03/98 & 10.4 & 76 & 7.8 & 8.0 & 30 & 10.0 & 3.0 & 0.7 & 1.5 & 0.6 & 0.13 & 9 & -- & $<45$ & $<5$ & $<0.1$ & $<5$ & 1 & 20 & $<1$ & 9 & $<5$ & $<5$ & $<0.1$ & $<1$ & 49 \\
\hline \multicolumn{27}{|c|}{ Site SW24SG, Silver Gulch at the confluence with the main stem of Clear Creek } \\
\hline 08/20/97 & 14.5 & 102 & 7.1 & 7.2 & 31 & 9.6 & 4.8 & $<2$ & 2.1 & $<0.5$ & $<0.2$ & 14 & 10.3 & $<40$ & $<1$ & 4.3 & $<0.8$ & 1.2 & $<5$ & 6.4 & 5 & $<11$ & $<1$ & $<0.2$ & $<1$ & 640 \\
\hline 09/24/97 & 14.0 & 122 & 8.0 & 7.4 & 36 & 11 & 6.2 & $<2$ & 2.3 & $<0.5$ & $<0.2$ & 19 & 9.4 & $<40$ & $<50$ & 2.9 & $<4$ & $<0.8$ & $<5$ & 3.9 & 1 & $<11$ & $<40$ & $<6$ & $<50$ & 770 \\
\hline 05/11/98 & 7.9 & 200 & 8.1 & 8.4 & 48 & 16 & 6.8 & 1.8 & 9.7 & 40 & 0.33 & 14 & -- & $<45$ & $<1$ & 2.6 & $<5$ & 1 & 60 & 1 & 4 & $<1$ & $<5$ & $<0.1$ & $<1$ & 660 \\
\hline 06/08/98 & 10.1 & 61 & 7.5 & -- & 22 & 5.5 & 2.7 & 1.1 & 1.7 & 0.8 & 0.06 & 9 & -- & $<45$ & $<1$ & 2.2 & $<5$ & $<1$ & $<10$ & 2 & $<1$ & $<1$ & $<5$ & $<0.1$ & $<1$ & 520 \\
\hline 08/10/98 & -- & 88 & 7.8 & -- & 30 & 9.2 & 4.0 & 0.8 & 2.2 & 0.8 & 0.09 & 13 & -- & $<45$ & $<5$ & 2.3 & $<5$ & $<1$ & $<10$ & 2 & $<5$ & $<5$ & $<5$ & $<0.1$ & $<1$ & 500 \\
\hline
\end{tabular}


Table 1. Water-quality data for samples collected at three sites upstream from Georgetown Lake, 1997-98-Continued

[See Appendix, table A2, for the methods of analysis used for these samples; ${ }^{\circ} \mathrm{C}$, degrees Celsius; $\mu \mathrm{S} / \mathrm{cm}$, microsiemens per centimeter at 25 degrees Celsius; $\mathrm{mg} / \mathrm{L}$, milligrams per liter; $\mu \mathrm{g} / \mathrm{L}$, micrograms per liter; <, less than; --, no data; see figure 2 for sampling-site locations]

\begin{tabular}{|c|c|c|c|c|c|c|c|c|c|c|c|c|c|c|c|c|c|c|c|c|}
\hline \multirow[b]{2}{*}{$\begin{array}{l}\text { Sampling } \\
\text { date }\end{array}$} & \multirow{2}{*}{$\begin{array}{c}\text { Hard- } \\
\text { ness } \\
(\mathrm{mg} / \mathrm{L} \text { as } \\
\left.\mathrm{CaCO}_{3}\right)\end{array}$} & \multirow{2}{*}{$\begin{array}{c}\text { Dissolved } \\
\text { organic } \\
\text { carbon } \\
\text { (mg/L } \\
\text { as C) }\end{array}$} & \multicolumn{13}{|c|}{$\begin{array}{c}\text { Total recoverable metals } \\
(\mu \mathrm{g} / \mathrm{L})\end{array}$} & \multicolumn{3}{|c|}{$\begin{array}{l}\text { Total nutrients } \\
\text { (mg/L) }\end{array}$} & \multirow{2}{*}{$\begin{array}{c}\text { Total } \\
\text { organic } \\
\text { carbon } \\
\text { (mg/L } \\
\text { as C) }\end{array}$} & \multirow{2}{*}{$\begin{array}{c}\text { Total } \\
\text { sus- } \\
\text { pended } \\
\text { solids } \\
\text { (mg/L) }\end{array}$} \\
\hline & & & Al & As & Cd & $\mathrm{Cr}$ & $\mathrm{Cu}$ & $\mathrm{Fe}$ & $\mathbf{P b}$ & Mn & $\mathbf{N i}$ & Se & $\mathrm{Ag}$ & TI & $\mathrm{Zn}$ & $\begin{array}{l}\text { Ammonia } \\
\text { (as N) }\end{array}$ & $\begin{array}{l}\text { Nitrite } \\
\text { plus } \\
\text { nitrate } \\
\text { (as N) }\end{array}$ & $\begin{array}{l}\text { Phos- } \\
\text { phorus } \\
\text { (as P) }\end{array}$ & & \\
\hline \multicolumn{21}{|c|}{ Site SW26, main stem of Clear Creek upstream from the confluence with South Clear Creek } \\
\hline 03/04/98 & 84.2 & $<1.5$ & 420 & $<50$ & 2.7 & $<4$ & 1.2 & 345 & 2 & 40 & $<11$ & -- & $<6$ & $<50$ & 910 & $<0.05$ & 0.29 & $<0.02$ & $<0.05$ & $<4$ \\
\hline 04/01/98 & 97.0 & 1 & 87 & $<1$ & 3.5 & $<5$ & 1 & 210 & 4 & 36 & $<5$ & -- & $<0.1$ & $<1$ & 970 & $<0.2$ & 0.31 & 0.02 & $<0.2$ & 6 \\
\hline $05 / 04 / 98$ & 75.9 & 3 & 150 & $<1$ & 2.4 & $<5$ & 2 & 310 & 2 & 40 & $<5$ & -- & $<0.1$ & $<1$ & 680 & $<0.2$ & 0.18 & 0.02 & $<0.2$ & 6 \\
\hline 06/01/98 & 32.5 & 5 & 150 & $<1$ & 0.8 & $<5$ & 2 & 220 & 5 & 15 & $<5$ & -- & 0.1 & $<1$ & 170 & $<0.2$ & $<0.05$ & $<0.01$ & $<0.2$ & $<5$ \\
\hline 07/06/98 & 29.5 & 4 & $<45$ & $<5$ & 0.4 & $<5$ & $<1$ & 100 & $<1$ & 8 & $<5$ & $<5$ & $<0.1$ & $<1$ & 120 & $<0.2$ & 0.10 & 0.01 & $<0.2$ & $<5$ \\
\hline 08/03/98 & 43.1 & -- & 68 & $<5$ & 0.6 & $<5$ & $<1$ & 140 & 1 & 14 & $<5$ & $<5$ & $<0.1$ & $<1$ & 180 & $<0.1$ & 0.16 & 0.01 & $<0.1$ & $<5$ \\
\hline \multicolumn{21}{|c|}{ Site SW25A, South Clear Creek upstream from the confluence with the main stem of Clear Creek } \\
\hline 03/04/98 & 56.3 & $<1.5$ & $<40$ & $<50$ & $<0.5$ & $<4$ & $<0.8$ & 40 & 0.9 & 10 & $<11$ & -- & $<6$ & $<50$ & 60 & $<0.05$ & 0.12 & $<0.02$ & $<0.05$ & $<4$ \\
\hline 04/01/98 & 74.5 & $<1$ & 66 & $<1$ & 0.2 & $<5$ & 1 & 120 & 4 & 20 & $<5$ & -- & $<0.1$ & $<1$ & 65 & $<0.2$ & 0.14 & 0.01 & $<0.2$ & $<5$ \\
\hline 05/04/98 & 61.4 & 1 & $<40$ & $<1$ & 0.2 & $<5$ & 1 & 70 & 1 & 10 & $<5$ & -- & $<0.1$ & $<1$ & 68 & $<0.2$ & 0.11 & $<0.01$ & $<0.2$ & $<5$ \\
\hline 06/01/98 & 34.1 & 5 & 110 & $<1$ & 0.4 & $<5$ & 5 & 180 & 6 & 41 & $<5$ & -- & $<0.1$ & $<1$ & 110 & $<0.2$ & $<0.05$ & 0.01 & $<0.2$ & $<5$ \\
\hline 07/06/98 & 32.2 & 4 & $<45$ & $<5$ & 0.2 & $<5$ & 1 & 60 & $<1$ & 12 & $<5$ & $<5$ & $<0.1$ & $<1$ & 62 & $<0.2$ & $<0.05$ & $<0.01$ & $<0.2$ & $<5$ \\
\hline 08/03/98 & 37.3 & -- & 56 & $<5$ & 0.1 & $<5$ & 2 & 120 & 2 & 18 & $<5$ & $<5$ & $<0.1$ & $<1$ & 55 & $<0.1$ & 0.10 & 0.01 & $<0.1$ & $<5$ \\
\hline \multicolumn{21}{|c|}{ Site SW24SG, Silver Gulch storm drain at the confluence with the main stem of Clear Creek } \\
\hline 08/20/97 & 43.7 & $<1.5$ & 49 & $<1$ & 4.5 & $<0.8$ & 3.4 & 35 & 9 & 6 & $<11$ & $<1$ & $<0.2$ & $<1$ & 660 & $<0.05$ & $<0.05$ & $<0.02$ & $<0.05$ & $<4$ \\
\hline $09 / 24 / 97$ & 53.7 & $<1.5$ & 106 & $<50$ & 3.8 & 3.8 & 1.2 & 150 & 8 & 4 & $<11$ & $<40$ & $<6$ & $<50$ & 780 & $<0.05$ & $<0.05$ & 0.03 & $<0.05$ & $<4$ \\
\hline 05/11/98 & 68.0 & 3 & 60 & $<1$ & 2.6 & $<5$ & 2 & 130 & 4 & 6 & $<5$ & -- & $<0.1$ & $<1$ & 610 & $<0.2$ & $<0.05$ & 0.02 & $<0.2$ & $<5$ \\
\hline 06/08/98 & 24.9 & 1 & 180 & $<1$ & 2.4 & $<5$ & 1 & 240 & 16 & 10 & $<5$ & -- & $<0.1$ & $<1$ & 500 & $<0.2$ & $<0.05$ & 0.02 & $<0.2$ & $<5$ \\
\hline 08/10/98 & 39.4 & 2 & 240 & $<5$ & 2.2 & $<5$ & 2 & 370 & 16 & 16 & $<5$ & $<5$ & $<0.1$ & $<1$ & 520 & $<0.1$ & $<0.05$ & 0.02 & $<0.1$ & 10 \\
\hline
\end{tabular}


Table 2. Estimated total recoverable loads for selected metals and nitrite plus nitrate at three sites upstream from Georgetown Lake, 1997-98

[Highlighting indicates loads calculated using one-half the reporting limit when sample concentration was below the reporting limit; $\mathrm{ft}^{3} / \mathrm{s}$, cubic feet per second; $\mathrm{kg} / \mathrm{d}$, kilograms per day; see figures 1 and 2 for sampling-site locations

\begin{tabular}{|c|c|c|c|c|c|c|c|c|c|}
\hline \multirow[b]{2}{*}{ Date } & \multirow[b]{2}{*}{$\begin{array}{c}\text { Discharge } \\
\left(\mathrm{ft}^{3} / \mathbf{s}\right)\end{array}$} & \multirow[b]{2}{*}{$\begin{array}{l}\text { Discharge } \\
\text { (liters per } \\
\text { second) }\end{array}$} & \multicolumn{7}{|c|}{ Estimated load } \\
\hline & & & $\begin{array}{c}\text { Cadmium } \\
(\mathrm{kg} / \mathrm{d})\end{array}$ & $\begin{array}{c}\text { Copper } \\
(\mathrm{kg} / \mathrm{d})\end{array}$ & $\begin{array}{l}\text { Iron } \\
(\mathrm{kg} / \mathrm{d})\end{array}$ & $\begin{array}{l}\text { Lead } \\
(\mathrm{kg} / \mathrm{d})\end{array}$ & $\begin{array}{l}\text { Manganese } \\
(\mathrm{kg} / \mathrm{d})\end{array}$ & $\begin{array}{c}\text { Zinc } \\
(\mathrm{kg} / \mathrm{d})\end{array}$ & $\begin{array}{c}\text { Nitrite plus } \\
\text { nitrate } \\
\text { (kg/d } \\
\text { as N) }\end{array}$ \\
\hline \multicolumn{10}{|c|}{ Site SW26, main stem of Clear Creek upstream from the confluence with South Clear Creek } \\
\hline 03/04/98 & 6.75 & $1.91 \times 10^{2}$ & $4.46 \times 10^{-2}$ & $1.98 \times 10^{-2}$ & 5.70 & $3.96 \times 10^{-2}$ & $6.61 \times 10^{-1}$ & $1.51 \times 10^{1}$ & 4.79 \\
\hline $04 / 01 / 98$ & 8.20 & $2.32 \times 10^{2}$ & $7.02 \times 10^{-2}$ & $2.01 \times 10^{-2}$ & 4.21 & $8.02 \times 10^{-2}$ & $7.22 \times 10^{-1}$ & $1.95 \times 10^{1}$ & 6.22 \\
\hline 05/04/98 & 31.8 & $9.00 \times 10^{2}$ & $1.87 \times 10^{-1}$ & $1.56 \times 10^{-1}$ & $2.41 \times 10^{1}$ & $1.56 \times 10^{-1}$ & 3.11 & $5.29 \times 10^{1}$ & $1.40 \times 10^{1}$ \\
\hline 06/01/98 & 170 & $4.81 \times 10^{3}$ & $3.33 \times 10^{-1}$ & $8.32 \times 10^{-1}$ & $9.15 \times 10^{1}$ & 2.08 & 6.24 & $7.07 \times 10^{1}$ & $1.04 \times 10^{1}$ \\
\hline 07/06/98 & 185 & $5.23 \times 10^{3}$ & $1.81 \times 10^{-1}$ & $2.26 \times 10^{-1}$ & $4.52 \times 10^{1}$ & $2.26 \times 10^{-1}$ & 3.61 & $5.42 \times 10^{1}$ & $4.52 \times 10^{1}$ \\
\hline 08/03/98 & 104 & $2.94 \times 10^{3}$ & $1.53 \times 10^{-1}$ & $1.27 \times 10^{-1}$ & $3.56 \times 10^{1}$ & $2.54 \times 10^{-1}$ & 3.56 & $4.58 \times 10^{1}$ & $4.07 \times 10^{1}$ \\
\hline \multicolumn{10}{|c|}{ Site SW25A, South Clear Creek upstream from the confluence with the main stem of Clear Creek } \\
\hline 03/04/98 & 6.16 & $1.74 \times 10^{2}$ & $3.77 \times 10^{-3}$ & $6.03 \times 10^{-3}$ & $6.03 \times 10^{-1}$ & $1.36 \times 10^{-2}$ & $1.51 \times 10^{-1}$ & $9.04 \times 10^{-1}$ & 1.81 \\
\hline $04 / 01 / 98$ & 5.34 & $1.51 \times 10^{2}$ & $2.61 \times 10^{-3}$ & $1.31 \times 10^{-2}$ & 1.57 & $5.23 \times 10^{-2}$ & $2.61 \times 10^{-1}$ & $8.49 \times 10^{-1}$ & 1.83 \\
\hline 05/04/98 & 11.2 & $3.17 \times 10^{2}$ & $5.48 \times 10^{-3}$ & $2.74 \times 10^{-2}$ & 1.92 & $2.74 \times 10^{-2}$ & $2.74 \times 10^{-1}$ & 1.86 & 3.01 \\
\hline 06/01/98 & 61.1 & $1.73 \times 10^{3}$ & $5.98 \times 10^{-2}$ & $7.47 \times 10^{-1}$ & $2.69 \times 10^{1}$ & $8.97 \times 10^{-1}$ & 6.13 & $1.64 \times 10^{1}$ & 3.74 \\
\hline 07/06/98 & 54.4 & $1.54 \times 10^{3}$ & $2.66 \times 10^{-2}$ & $1.33 \times 10^{-1}$ & 7.99 & $6.65 \times 10^{-2}$ & 1.60 & 8.25 & 3.33 \\
\hline 08/03/98 & 56.0 & $1.59 \times 10^{3}$ & $1.37 \times 10^{-2}$ & $2.74 \times 10^{-1}$ & $1.64 \times 10^{1}$ & $2.74 \times 10^{-1}$ & 2.47 & 7.54 & $1.37 \times 10^{1}$ \\
\hline \multicolumn{10}{|c|}{ Site SW24SG, Silver Gulch at the confluence with the main stem of Clear Creek } \\
\hline 08/20/97 & 0.14 & 3.96 & $1.54 \times 10^{-3}$ & $1.16 \times 10^{-3}$ & $1.20 \times 10^{-2}$ & $3.12 \times 10^{-3}$ & $2.06 \times 10^{-3}$ & $2.26 \times 10^{-1}$ & $8.56 \times 10^{-3}$ \\
\hline 09/24/97 & 0.08 & 2.27 & $7.44 \times 10^{-4}$ & $2.35 \times 10^{-4}$ & $2.90 \times 10^{-2}$ & $1.62 \times 10^{-3}$ & $7.83 \times 10^{-4}$ & $1.53 \times 10^{-1}$ & $4.89 \times 10^{-3}$ \\
\hline $05 / 11 / 98$ & 0.02 & $5.66 \times 10^{-1}$ & $1.27 \times 10^{-4}$ & $9.79 \times 10^{-5}$ & $6.36 \times 10^{-3}$ & $1.96 \times 10^{-4}$ & $2.94 \times 10^{-4}$ & $2.98 \times 10^{-2}$ & $1.22 \times 10^{-3}$ \\
\hline 06/08/98 & 2.46 & $6.97 \times 10^{1}$ & $1.44 \times 10^{-1}$ & $6.02 \times 10^{-3}$ & 1.44 & $9.63 \times 10^{-2}$ & $6.02 \times 10^{-2}$ & 3.01 & $1.50 \times 10^{-1}$ \\
\hline 08/10/98 & 0.15 & 4.25 & $8.07 \times 10^{-4}$ & $7.34 \times 10^{-4}$ & $1.36 \times 10^{-1}$ & $5.87 \times 10^{-3}$ & $5.87 \times 10^{-3}$ & $1.91 \times 10^{-1}$ & $9.17 \times 10^{-3}$ \\
\hline
\end{tabular}




\section{Inflow and Outflow Discharge}

Streamflow-measurement gages were installed upstream and downstream from the reservoir. The upstream (inflow) gage (station 394308105413800, Clear Creek above Georgetown Lake near Georgetown, Colorado) was installed about $350 \mathrm{ft}$ upstream from the reservoir inflow (fig. 1). Water depth (stage) was measured with a pressure transducer positioned near the bottom of the streambed. The downstream (outflow) gage (station 394359105411900 , Clear Creek below Georgetown Lake near Georgetown, Colorado) was installed in the concrete channel leading to the spillway (about $10 \mathrm{ft}$ upstream from the dam spillway) (fig. 1). At the outflow gage, a pressure transducer was positioned about 18 inches below the normal lake surface to record water depth. Because it was impractical to make discharge measurements at the spillway and because streambed rubble below the spillway made it impossible to obtain an accurate discharge measurement near the dam, calibration discharge measurements were made about 1,600 ft downstream from the spillway, where a bridge provided access during high flow when the stream was not wadeable. The site included the outflow from the Georgetown Wastewater Treatment Plant, which enters Clear Creek about $300 \mathrm{ft}$ downstream from the dam. Normal outflow from the plant was less than $0.2 \mathrm{ft}^{3} / \mathrm{s}$ (about 1.6 percent of low flow and about 0.07 percent of high flow) (Thomas Rickenson, Georgetown Wastewater Treatment Plant, oral commun., 1997), which had minimal effect on the overall discharge measurement.

At both gages, pressure-transducer depth measurements were recorded every 15 minutes on continuously recording data loggers. To develop the stage-discharge curves for the gages, discharge measurements were made periodically. The mean daily discharge records for the sites are available in the USGS National Water Information System data base and are reported in Crowfoot and others (1998) and Crowfoot and others (1999). Daily discharge data for the reservoir inflow and outflow are presented in figure 3; inflow and outflow discharges are nearly equal, implying that storage effects are negligible.

\section{Bathymetry and Average Residence Time}

To estimate average residence time of water in Georgetown Lake, a bathymetric survey was done by the Bureau of Reclamation (Ronald Ferrari and Kent Collins, Bureau of Reclamation, written commun., 1997). The bathymetric survey measured the topography of the reservoir bottom, which enabled development of a relation between reservoir depth and storage capacity. A boat equipped with electronic surveying equipment made transects back and forth across the reservoir. A survey of the lake shoreline was done using a global positioning system because shallow water near the shoreline prevented precise measurement of the shoreline coordinates by boat. The digital data were loaded into a geographical information system (GIS) from which a map of the reservoir bottom was generated and the storage capacity of the reservoir was calculated to be about 440 acre-feet (William Schroeder, U.S. Environmental Protection Agency, written commun., 1997).

Average reservoir residence time as a function of discharge (fig. 4) was calculated by assuming that storage was constant. If about $2.5 \mathrm{ft}$ of a 3 -ft-thick ice cover is submerged in the reservoir, the displaced volume can have a major effect on average residence time. For a discharge of $10 \mathrm{ft}^{3} / \mathrm{s}$, the average residence time is about 22 days when the reservoir is free of ice, but would be shortened to about 15 days with a 3 -ft-thick ice cover. During high flow, average residence time in Georgetown Lake is about 1 to 3 days.

\section{Bed-Sediment Chemistry}

Bed sediment is a potential source of metals to the reservoir water. To quantify the types and amounts of metals present in the bed sediments, samples were collected from six sites near the depthprofile-sampling sites (fig. 2; SW24S series) on March 23, 1998. Because coarse sand and small pebbles in the sediment made it impossible to drive a core sampler to sufficient depths to collect samples, a ponar dredge was used. Sediment was collected from the interior of the dredge (avoiding contact with the metal sides) with plastic utensils and placed into plastic sample containers. These containers were placed on ice and transported to the laboratory. Sediment samples for determining populations of sulfate-reducing bacteria also were collected at 


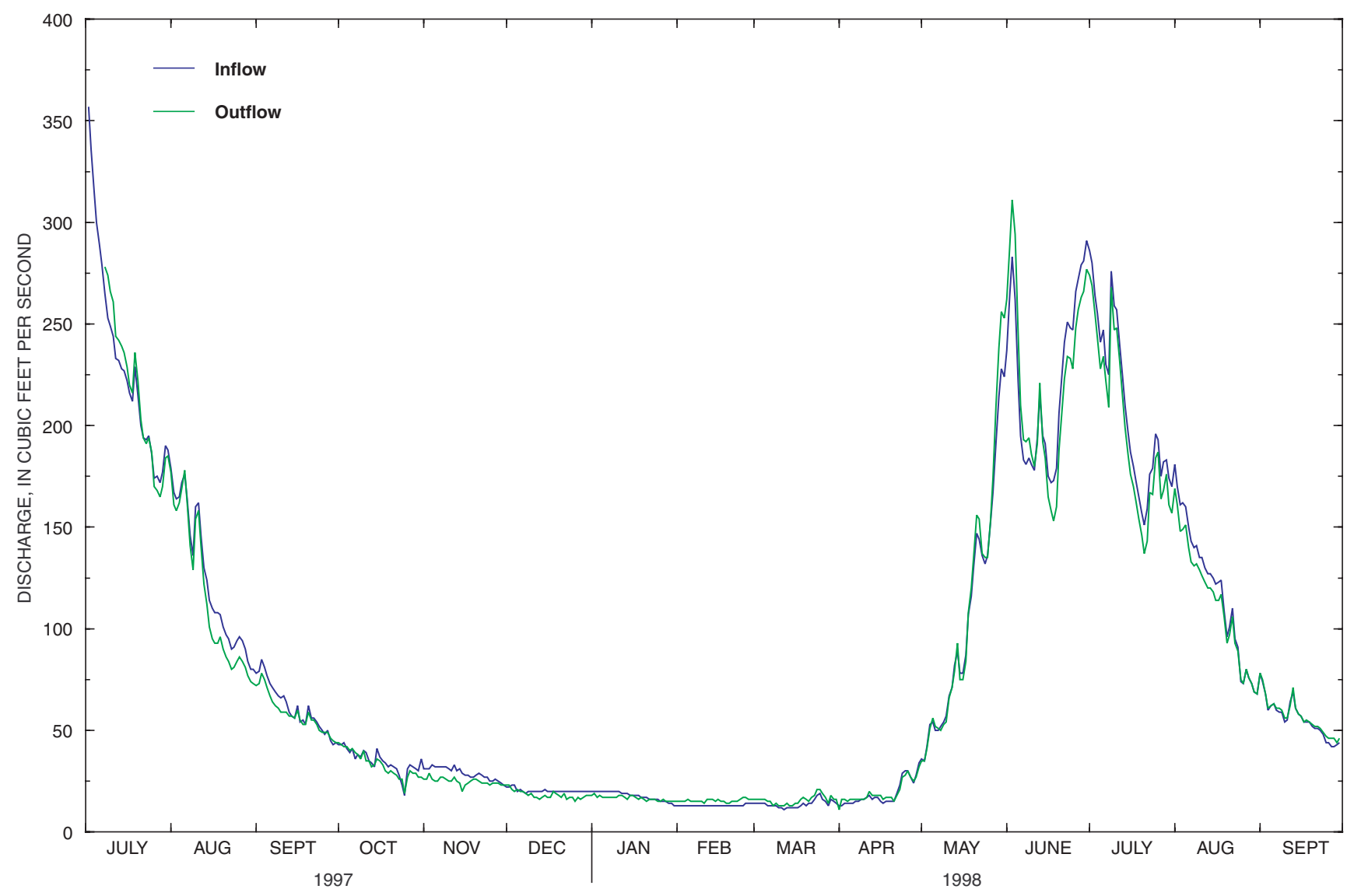

Figure 3. Georgetown Lake inflow and outflow discharge, July 1997 through September 1998.

four of the six bed-sediment sampling sites during March 1998 using the ponar dredge. Because sulfatereducing bacteria are anaerobic, contact of the sample with air was minimized by keeping the ponar dredge submerged while samples were collected. Sediment samples were placed on ice for transport to the laboratory.

The bed-sediment samples were analyzed for aluminum, arsenic, cadmium, chromium, copper, iron, lead, manganese, and zinc (table 3). Iron had the highest average concentration $(25,500 \mathrm{mg} / \mathrm{kg})$. Sediment in four lakes and reservoirs in the South Clear Creek Basin upstream from Georgetown Lake contained similar iron concentrations (average concentration 38,300 mg/kg) (M.R. Stevens, U.S. Geological Survey, written commun., 1998). Large average concentrations of aluminum $(12,300 \mathrm{mg} / \mathrm{kg})$, zinc $(2,830 \mathrm{mg} / \mathrm{kg})$, lead $(618 \mathrm{mg} / \mathrm{kg})$, and manganese $(548 \mathrm{mg} / \mathrm{kg})$ also were measured in the six bedsediment samples. The flows in Clear Creek and
South Clear Creek during spring and summer snowmelt runoff transport sediments to Georgetown Lake. Sediment from the surrounding hillsides also enters the reservoir during snowmelt and during heavy rainstorms in the summer. The extensive wetlands and beaver ponds that existed before Georgetown Lake was created also possibly left a substantial supply of metals underlying younger sediment.

Bed-sediment samples also were analyzed for sulfide content (table 3). Sulfide concentrations generally increased from the reservoir inflow $(230 \mathrm{mg} / \mathrm{kg}$ as $\mathrm{S})$ to the outflow $(1,010 \mathrm{mg} / \mathrm{kg}$ as $\mathrm{S})$. The odor of hydrogen sulfide gas was noticeable when the sediment samples were collected, indicating anoxic conditions. When anoxic conditions exist in sediments, sulfate ions are reduced to sulfide ions. The presence of large populations of sulfate-reducing bacteria in the sediment (table 4) indicates strongly reducing conditions. 


\section{Types of Benthic Algae}

During reconnaissance trips to Georgetown Lake, it was observed that a layer of algae and other aquatic plants grew on the lake bottom. Because the presence of algae can affect the chemistry of water, algae samples were collected for qualitative taxonomical identification at two of the bed-sediment sampling sites. These samples also were collected with the ponar dredge, and the algae were carefully removed from the surface of the sediment. The algae samples were placed in a plastic sample container filled with reservoir water and were stored on ice for delivery to the laboratory. Results provided by the USEPA laboratory (table 5) (Henry Bell, U.S. Environmental Protection Agency, written commun., 1998) were modified to conform to the USGS National Water Quality Laboratory, Biological Unit, Algae Report Phylogenetic Order. Most of the genera identified are relatively common in cold-water lakes. One of the reported genera (Nitzschia) has the ability to withstand low-light conditions (Hill, 1996).

Stresses to algal populations include cold water and diminished light intensity. Georgetown Lake temperatures ranged from $0^{\circ}$ to $14^{\circ} \mathrm{C}$ during the study. Temperature affects algal photosynthetic metabolism through its control of enzyme reaction rates; temperatures for optimal growth differ among species, and populations may adapt to habitats that never provide optimal conditions (DeNicola, 1996).

A Secchi disk was used during the summer months to estimate the light transmission through the reservoir water column. Most of the time, the disk could easily be seen on the bottom of the reservoir, but on two occasions sediments were suspended by high winds or high flow and the disk was visible only to a depth of about $3 \mathrm{ft}$.

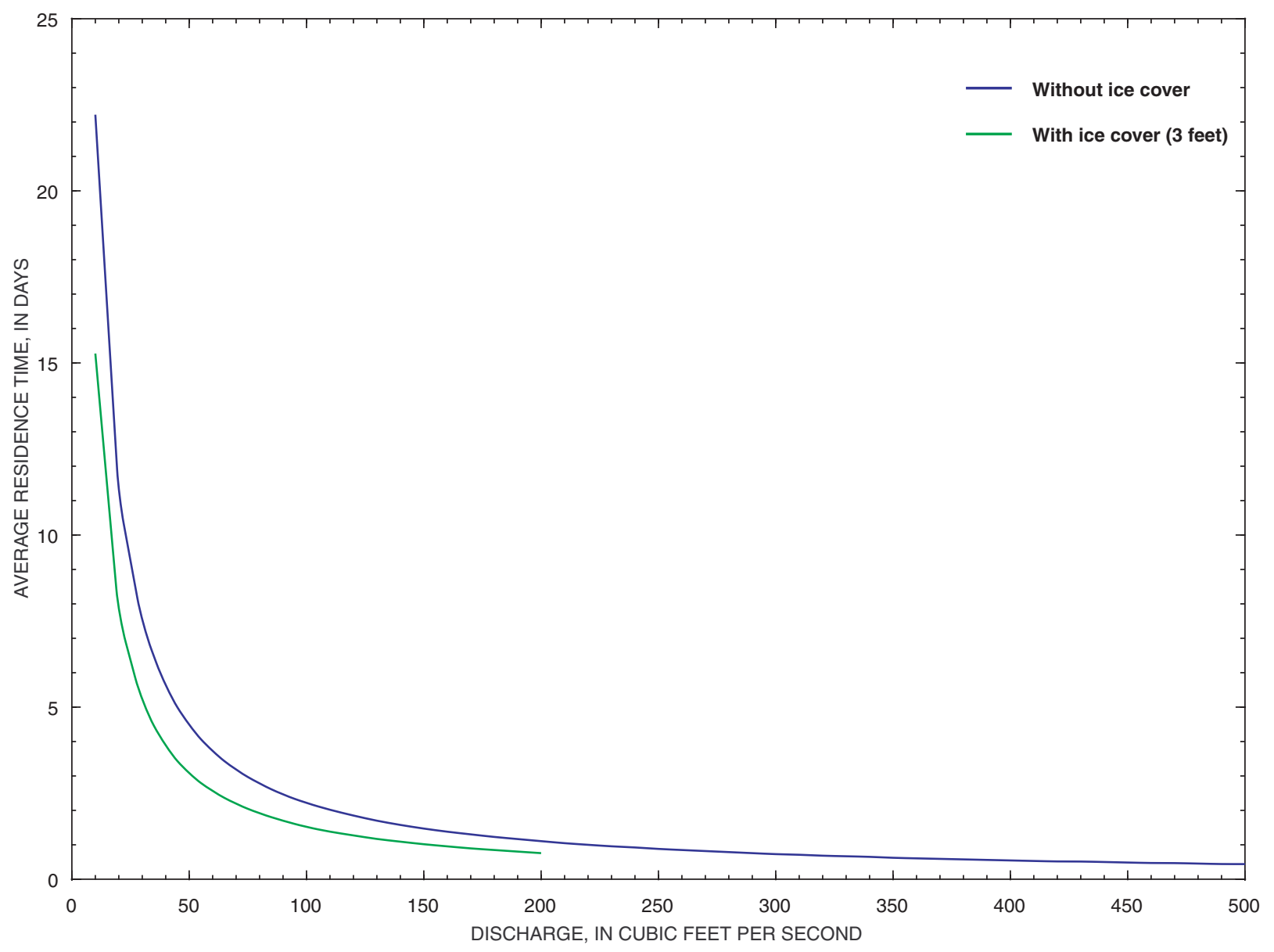

Figure 4. Estimated average residence time for Georgetown Lake. 
Table 3. Chemical data for reservoir-sediment samples collected from Georgetown Lake, March 23, 1998

[mg/kg, milligrams per kilogram; <, less than; see figure 2 for sampling-site locations]

\begin{tabular}{|c|c|c|c|c|c|c|c|c|c|c|c|}
\hline \multirow{2}{*}{$\begin{array}{l}\text { Sampling } \\
\text { site }\end{array}$} & \multicolumn{9}{|c|}{$\begin{array}{l}\text { Metals, by partial digestion } \\
(\mathrm{mg} / \mathrm{kg})\end{array}$} & \multirow{2}{*}{$\begin{array}{l}\text { Percentage } \\
\text { of solids }\end{array}$} & \multirow{2}{*}{$\begin{array}{c}\text { Sulfides } \\
\text { (mg/kg } \\
\text { as S) }\end{array}$} \\
\hline & Al & As & Cd & $\mathrm{Cr}$ & $\mathrm{Cu}$ & $\mathrm{Fe}$ & $\mathbf{P b}$ & Mn & Zn & & \\
\hline SW24S1 & 11,350 & 15 & 15.2 & 28.3 & 98.4 & 30,530 & 665 & 867 & 2,046 & 46.1 & 230 \\
\hline SW24S2 & 11,240 & 15 & 13.0 & 27.7 & 94.2 & 31,240 & 810 & 800 & 2,058 & 22.8 & 300 \\
\hline SW24S3 & 8,285 & 8 & 15.6 & 19.6 & 78.1 & 15,700 & 458 & 281 & 2,754 & 37.0 & 815 \\
\hline SW24S4 & 14,940 & $<5$ & 10.5 & 37.1 & 69.9 & 25,550 & 409 & 411 & 2,088 & 40.6 & 528 \\
\hline SW24S5 & 14,870 & 5 & 23.4 & 35.1 & 106.6 & 24,480 & 682 & 410 & 4,108 & 29.7 & 724 \\
\hline SW24S6 & 13,350 & 8 & 18.6 & 32.9 & 95.9 & 25,260 & 689 & 516 & 3,941 & 36.0 & 1,010 \\
\hline
\end{tabular}

Table 4. Sulfate-reducing bacteria data for sediment samples collected from Georgetown Lake, March 23, 1998

[Modified from: Mark Hernandez, Hernandez \& Associates, written commun., 1998: MPN, most probable number of bacteria; mg/mL, milligrams per milliliter; mL, milliliters; see figure 2 for sampling-site locations]

\begin{tabular}{|c|c|c|c|c|c|c|c|c|c|c|c|}
\hline \multirow[t]{2}{*}{$\begin{array}{l}\text { Sampling } \\
\text { site }\end{array}$} & \multirow{2}{*}{$\begin{array}{l}\text { Sediment } \\
\text { concentration } \\
\text { tested, } \\
\text { total solids } \\
(\mathrm{mg} / \mathrm{mL})\end{array}$} & \multirow{2}{*}{$\begin{array}{c}\text { Sediment } \\
\text { organic } \\
\text { content, } \\
\text { volatile solids } \\
\text { (percentage of } \\
\text { total solids) }\end{array}$} & \multicolumn{4}{|c|}{$\begin{array}{l}\text { Number of sulfide- } \\
\text { positive samples out of } \\
\text { five replicates at various } \\
\text { dilution factors }{ }^{1}\end{array}$} & \multirow[t]{2}{*}{$\begin{array}{l}\text { MPN } \\
\text { Index }\end{array}$} & \multirow[t]{2}{*}{$\begin{array}{c}\text { MPN/ } \\
100 \mathrm{~mL}\end{array}$} & \multirow[t]{2}{*}{$\begin{array}{c}\text { MPN/gram } \\
\text { sediment }\end{array}$} & \multirow{2}{*}{$\begin{array}{c}\text { 95-percent } \\
\text { lower } \\
\text { confidence } \\
\text { limit, } \\
\text { MPN/gram } \\
\text { sediment }\end{array}$} & \multirow{2}{*}{$\begin{array}{c}\text { 95-percent } \\
\text { upper } \\
\text { confidence } \\
\text { limit, } \\
\text { MPN/gram } \\
\text { sediment }\end{array}$} \\
\hline & & & $10^{-1}$ & $10^{-2}$ & $10^{-3}$ & $10^{-4}$ & & & & & \\
\hline SW24S2 & 48 & 10 & 5 & 5 & 4 & 0 & 1,600 & 160,000 & $3.3 \times 10^{6}$ & $1.3 \times 10^{6}$ & $1.1 \times 10^{7}$ \\
\hline SW24S3 & 13 & 12 & 5 & 4 & 0 & 0 & 130 & 13,000 & $1.0 \times 10^{6}$ & $3.8 \times 10^{5}$ & $3.0 \times 10^{6}$ \\
\hline SW24S4 & 12 & 11 & 5 & 4 & 0 & 0 & 130 & 13,000 & $1.1 \times 10^{6}$ & $4.2 \times 10^{5}$ & $3.3 \times 10^{6}$ \\
\hline SW24S6 & 8 & 12 & 5 & 4 & 1 & 0 & 170 & 17,000 & $2.1 \times 10^{6}$ & $8.8 \times 10^{5}$ & $6.0 \times 10^{6}$ \\
\hline
\end{tabular}

${ }^{1}$ Presence of sulfate-reducing bacteria. Each dilution series included control vials without inoculum. All control vials were negative for sulfide.

${ }^{2}$ Method modified for dilution series used from Standard Methods for the Examination of Water and Wastewater (American Public Health Association and others, 1989).

Ice substantially affects the amount of light available to algae and other plants. Georgetown Lake usually is covered with a thick layer of ice ( $3 \mathrm{ft}$ of ice was measured in February and March 1998) from late November or early December through late March or early April. Light transmission through a thin layer (about 4 inches) of clear, colorless ice is only slightly less than light transmission through water; thicker, clear ice, however, decreases light transmission by about 50 percent (for about 42 inches) (Wetzel, 1983). Staining and bubbles in the ice can further reduce light transmission. Dense, wet snow on ice can decrease light transmission by 95 to 99 percent. Although the ice on Georgetown Lake is covered with snow during the numerous winter snowfalls, high winds usually remove most of the snow from the ice within a few days. Most of the ice on the reservoir during the early months of 1998 was opaque and colored, but large areas of ice were clear, containing few bubbles.

\section{Depth Profiles of Water Chemistry}

To investigate potential reservoir stratification, field-measurement profiles were made at seven sites on Georgetown Lake on July 28, 1997 (fig. 5) to represent a period of relatively high discharge (about $170 \mathrm{ft}^{3} / \mathrm{s}$ ) and warm temperature. Profiles were measured at six sites on February 13, 1998 (fig. 6), to represent a period of low discharge (about $15 \mathrm{ft}^{3} / \mathrm{s}$ ) and ice-covered conditions. Measurements of temperature, specific conductance, $\mathrm{pH}$, and dissolvedoxygen concentrations were made by lowering a multiparameter sensor down through the reservoir water column and recording data at selected depths.

\section{Field Measurements}

Profiles of temperature (fig. 7) and specific conductance (fig. 8) show that on July 28, 1997, water in the reservoir was well mixed, although temperature increased from about $10^{\circ} \mathrm{C}$ to $11^{\circ} \mathrm{C}$ as water flowed 
through the reservoir. Thorough mixing can be attributed primarily to the relatively large inflow discharge (about $170 \mathrm{ft}^{3} / \mathrm{s}$; fig. 3), resulting in an average residence time of about 1.3 days (fig. 4), but wave action by strong winds probably facilitated mixing. By contrast, on February 13, 1998, temperature and specific conductance were stratified in the reservoir, which can be attributed to ice cover and a small inflow discharge of about $15 \mathrm{ft}^{3} / \mathrm{s}$ (fig. 3), resulting in an average residence time of about 12 days (fig. 4). Temperatures increased from about $0.2-1.0^{\circ} \mathrm{C}$ directly beneath the ice to about $3.8^{\circ} \mathrm{C}$ about halfway down the

Table 5. Qualitative taxonomical identification of algae and diatoms collected from surface of Georgetown Lake sediment, 1997-98

[Algae/diatom information modified to conform to U.S. Geological Survey National Water Quality Laboratory Biological Unit Algae Report Phylogenetic Order (National Water Quality Laboratory, October 6, 1998); modified from: Henry Bell, Environmental Services Assistance Teams-Western Zone-Region 8, Lockheed Martin Corporation, written commun., 1998; order in which data are presented does not imply relative quantity or predominance; see fig. 2 for sampling-site locations]

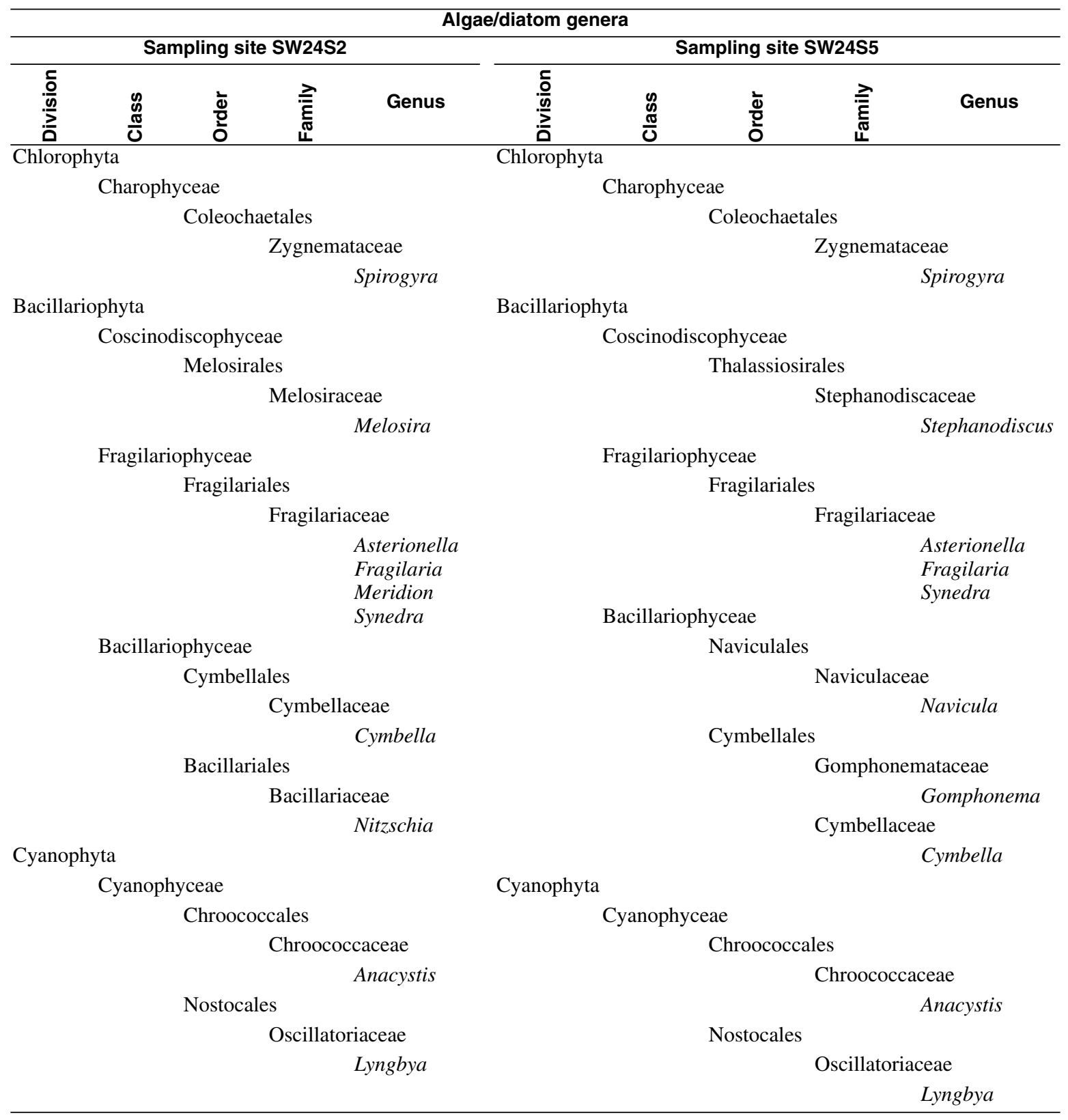




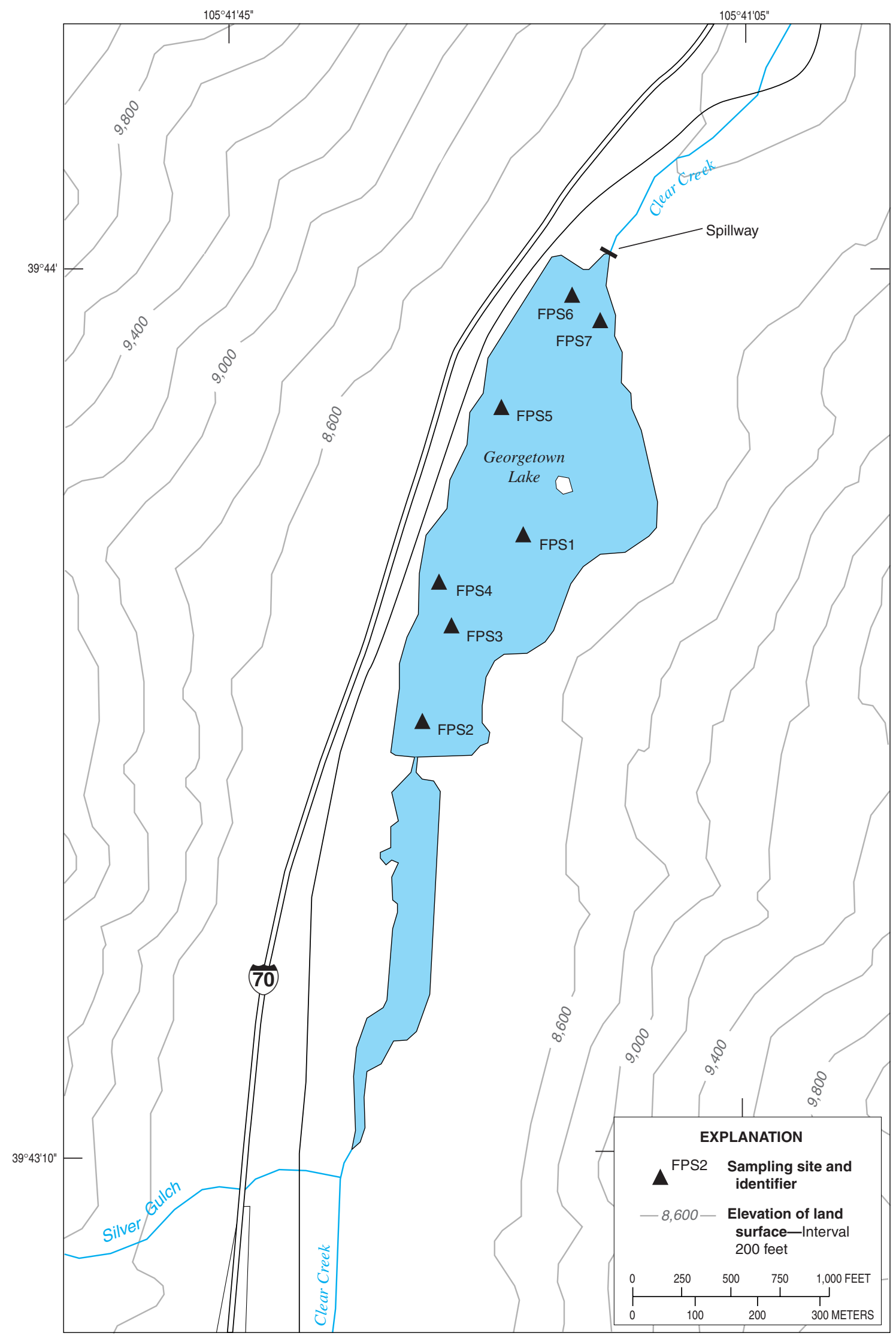

Figure 5. Location of field-measurement-profile sites on Georgetown Lake, July 28, 1997. 


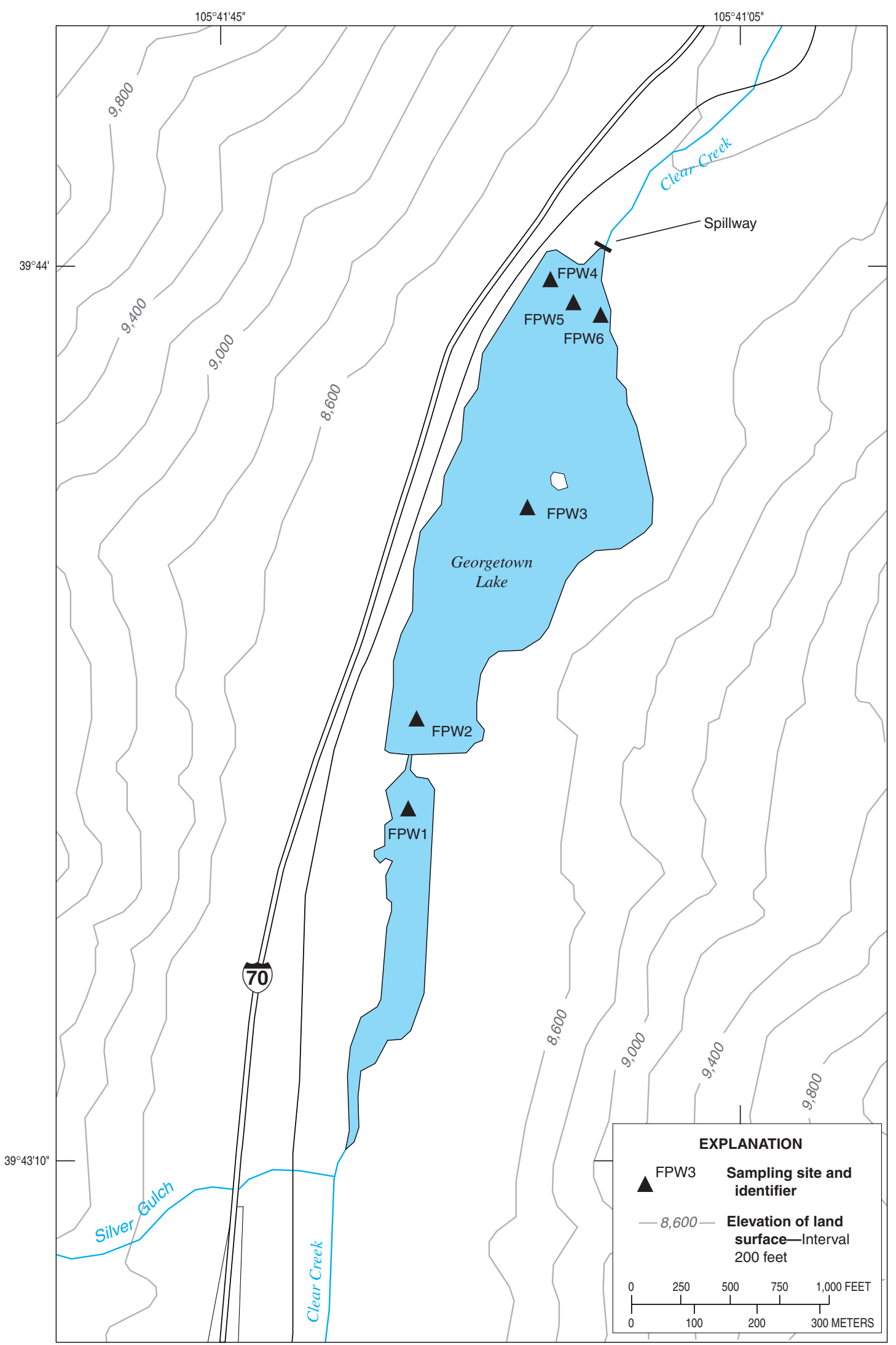

Figure 6. Location of field-measurement-profile sites on Georgetown Lake, February 13, 1998. 

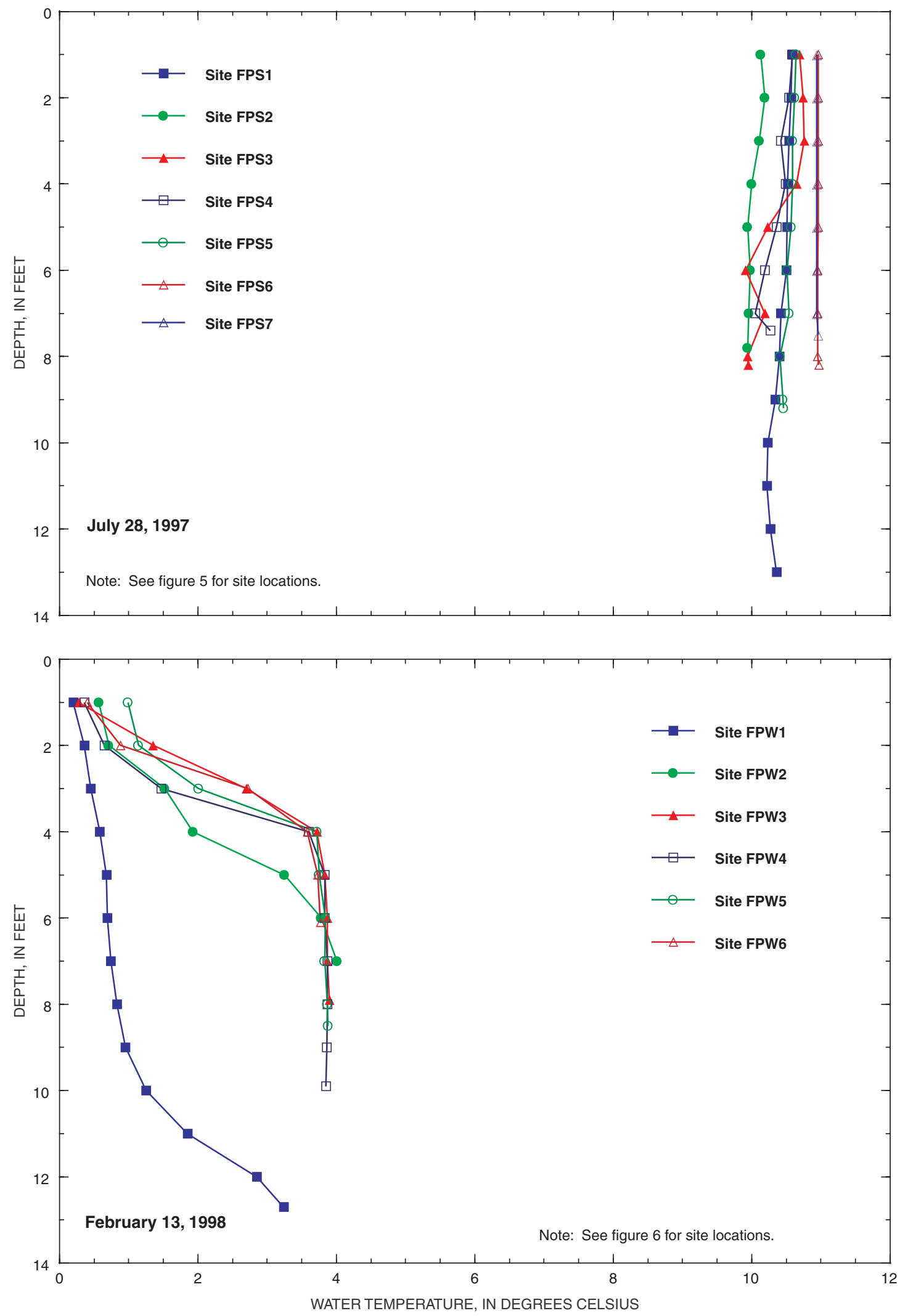

Figure 7. Water-temperature profiles in Georgetown Lake, July 28, 1997, and February 13, 1998. 

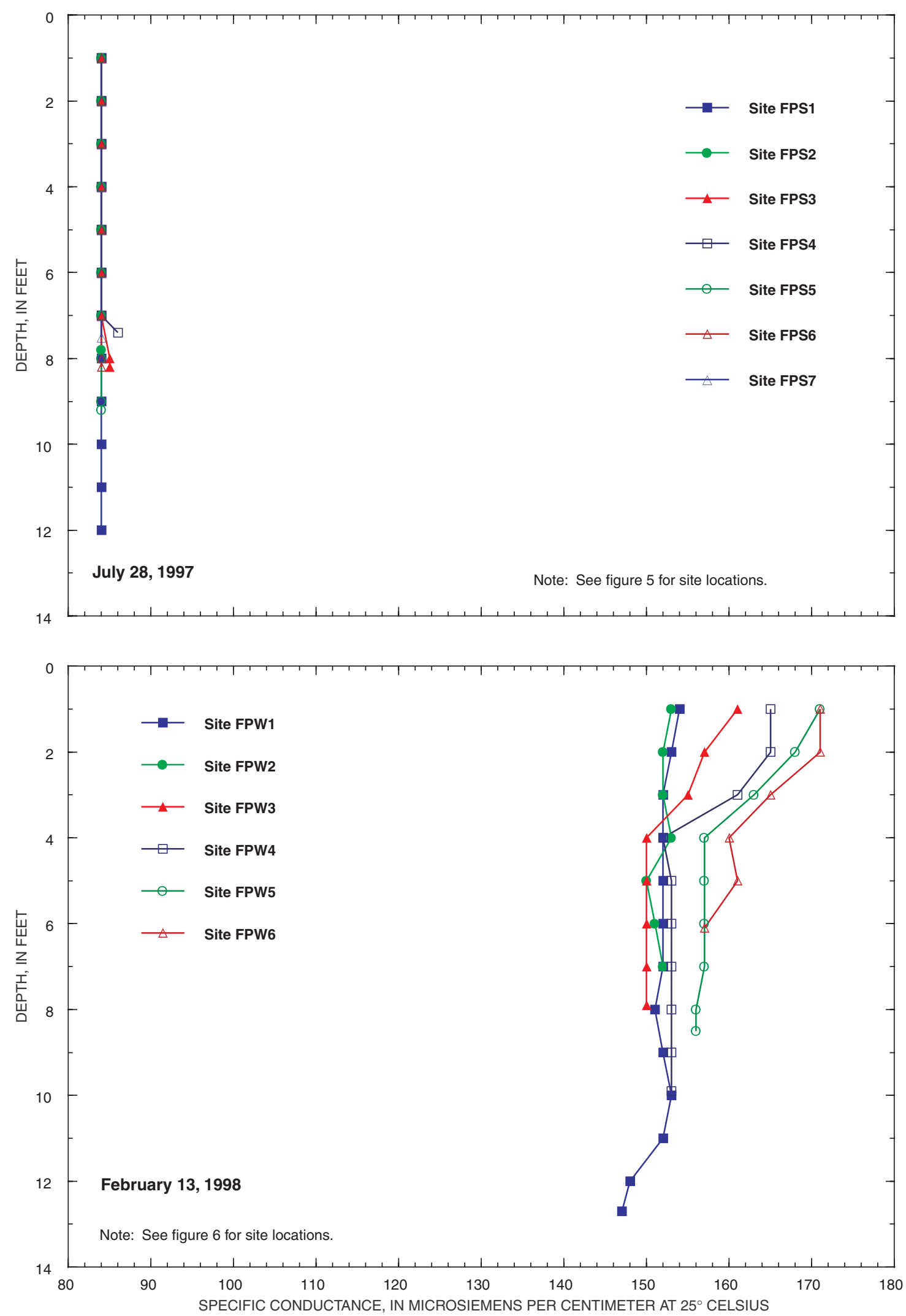

Figure 8. Specific-conductance profiles in Georgetown Lake, July 28, 1997, and February 13, 1998. 
water column and remained near $3.8^{\circ} \mathrm{C}$ to bottom. Temperature profiles for the larger pool of the reservoir (sites FPW2 through FPW6; fig. 6) show a relatively constant temperature of about $3.8^{\circ} \mathrm{C}$ below a depth of about $4 \mathrm{ft}$. In the smaller reservoir pool (site FPW1; fig. 6), however, temperature increased only slightly to a depth of about 70 percent of total depth, then increased at a greater rate to about $3.3^{\circ} \mathrm{C}$ near the bottom; this more gradual temperature transition resulted from more rapid flow of water through the narrower, upper reservoir pool. In the deeper, denser layer of water, specific conductance was less variable and about 5 percent smaller, on average, than in the overlying layer. Specific conductance was almost twice as great on February 13, 1998, as on July 28, 1997, because of the dilution of solutes associated with the larger inflow discharge during summer snowmelt.

Profiles of $\mathrm{pH}$ (fig. 9) and dissolved-oxygen concentration (fig. 10) also show that the reservoir was vertically well mixed on July 28, 1997, except for abrupt increases near the bottom in most of the profiles. These increases can be attributed to substantial photosynthesis by aquatic vegetation on the bottom that produces dissolved oxygen and removes carbon dioxide from the water, increasing the $\mathrm{pH}$ to as high as 10 in some lakes (Sawyer and McCarty, 1978). The water column was well oxygenated at all profile sites; dissolved-oxygen concentrations ranged from about 8.4 to $11.0 \mathrm{mg} / \mathrm{L}$ (saturated to oversaturated), and oversaturation resulted from photosynthesis. On February 13, 1998, pH and dissolved-oxygen concentrations had greater variation with depth. Higher $\mathrm{pH}$ and higher concentrations of dissolved oxygen tended to occur higher in the water column than on July 28, 1997, and generally approached peak values at depths of 3-5 ft. These patterns indicate that the effects of photosynthesis extended upward to shallower depths during winter than during summer.

$\mathrm{pH}$ and dissolved-oxygen concentration at sites FPW2 and FPW6 on February 13, 1998, increased downward to 1-3 ft above the bottom, indicating photosynthesis, but decreased near the bottom. The decreases near the bottom probably resulted from plant respiration or bacterial oxidation of organic matter, which consumes oxygen and produces carbon dioxide. On February 13, 1998, median $\mathrm{pH}$ of all profiles was about 0.5 unit higher than on July 28, 1997. Dissolved-oxygen concentrations also were greater during winter than summer, ranging from 8.9 (saturated) to $15.3 \mathrm{mg} / \mathrm{L}$ (oversaturated). Higher $\mathrm{pH}$ during winter than summer, though partly the result of increased alkalinity, largely resulted from greater effects of photosynthesis during winter. Higher dissolvedoxygen concentrations in winter partly resulted from greater solubility at lower water temperature, but photosynthesis caused most of the increase; this conclusion is indicated by the generally larger increases in dissolved-oxygen concentrations with depth during winter than during summer and the substantially larger downstream increases in dissolved-oxygen concentrations during winter than during summer. The greater effects of photosynthesis in reservoir water during winter resulted more from the longer average residence time in winter rather than greater rates of photosynthesis. Photosynthesis rates probably were actually slower during winter, when temperatures were lower and the reservoir was covered with ice.

\section{Metals}

Reservoir-profile samples for major dissolved constituents, dissolved metals, dissolved organic carbon, total recoverable metals, and total organic carbon were collected through the ice at six sites (fig. 2; SW24P series) on March 11-12, 1998.

Samples were collected from directly below the ice and near the reservoir bottom at four of those locations (two samples per profile) with an additional sample collected in the thermal transition zone (metalimnion) at two locations (three samples per profile). To collect the samples, a weighted nylon line with Tygon tubing attached was lowered through the ice and water was pumped with a peristaltic pump to a processing chamber above the surface of the ice.

Results of analyses of dissolved metal concentrations (table 6) and total recoverable metal concentrations (table 6; fig. 11) collected at six profile sites (fig. 2) on March 11-12, 1998, show higher concentrations of cadmium and zinc directly under the ice and higher concentrations of iron, lead, and manganese near the bottom of the reservoir. These relations indicate that reservoir sediments probably were a net source of iron, lead, and manganese and a net sink of cadmium and zinc.

Samples collected on March 4, 1998, when compared to profile samples collected on March 11-12, 1998, indicate that water at the outflow 

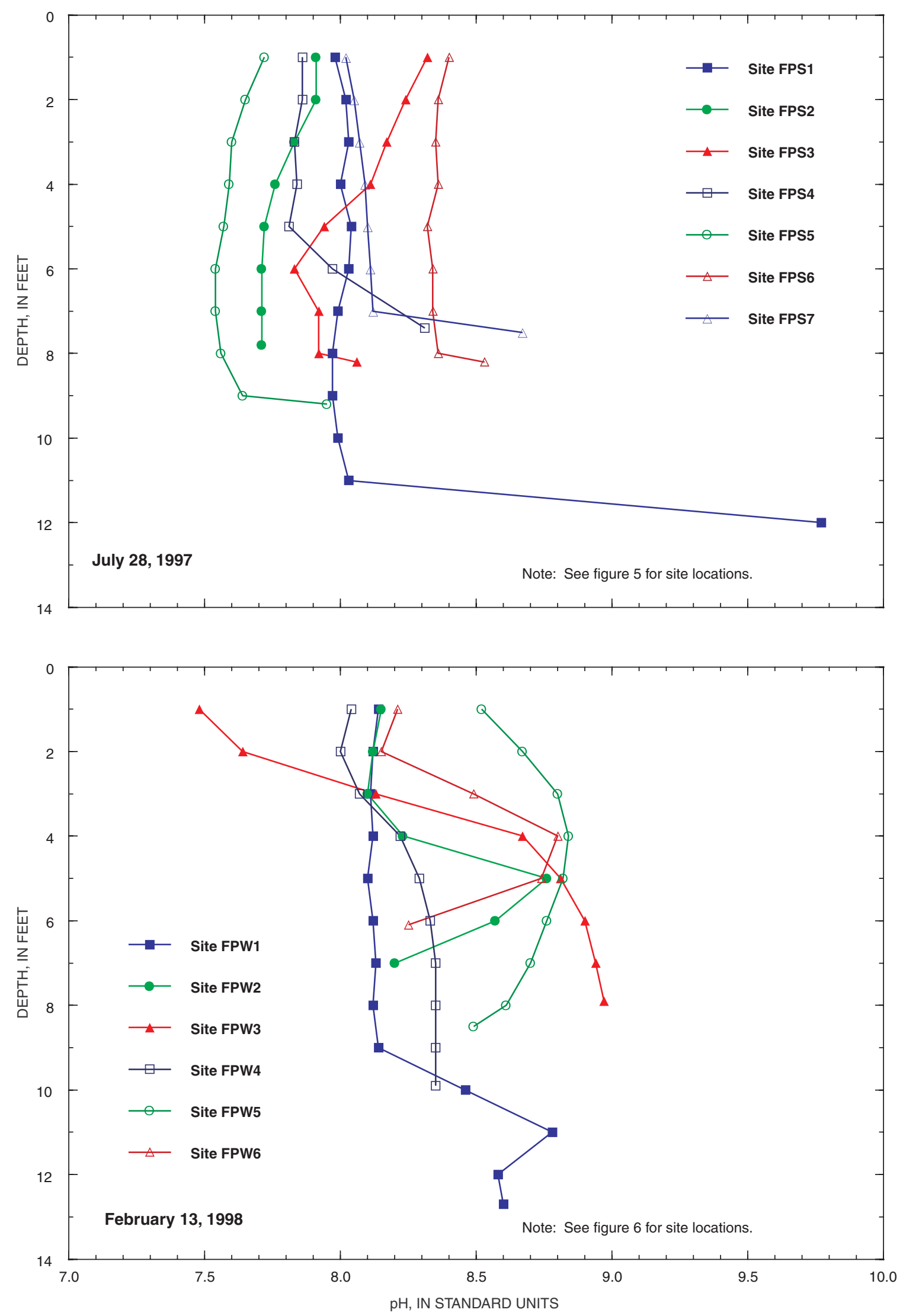

Figure 9. pH profiles in Georgetown Lake, July 28, 1997, and February 13, 1998. 

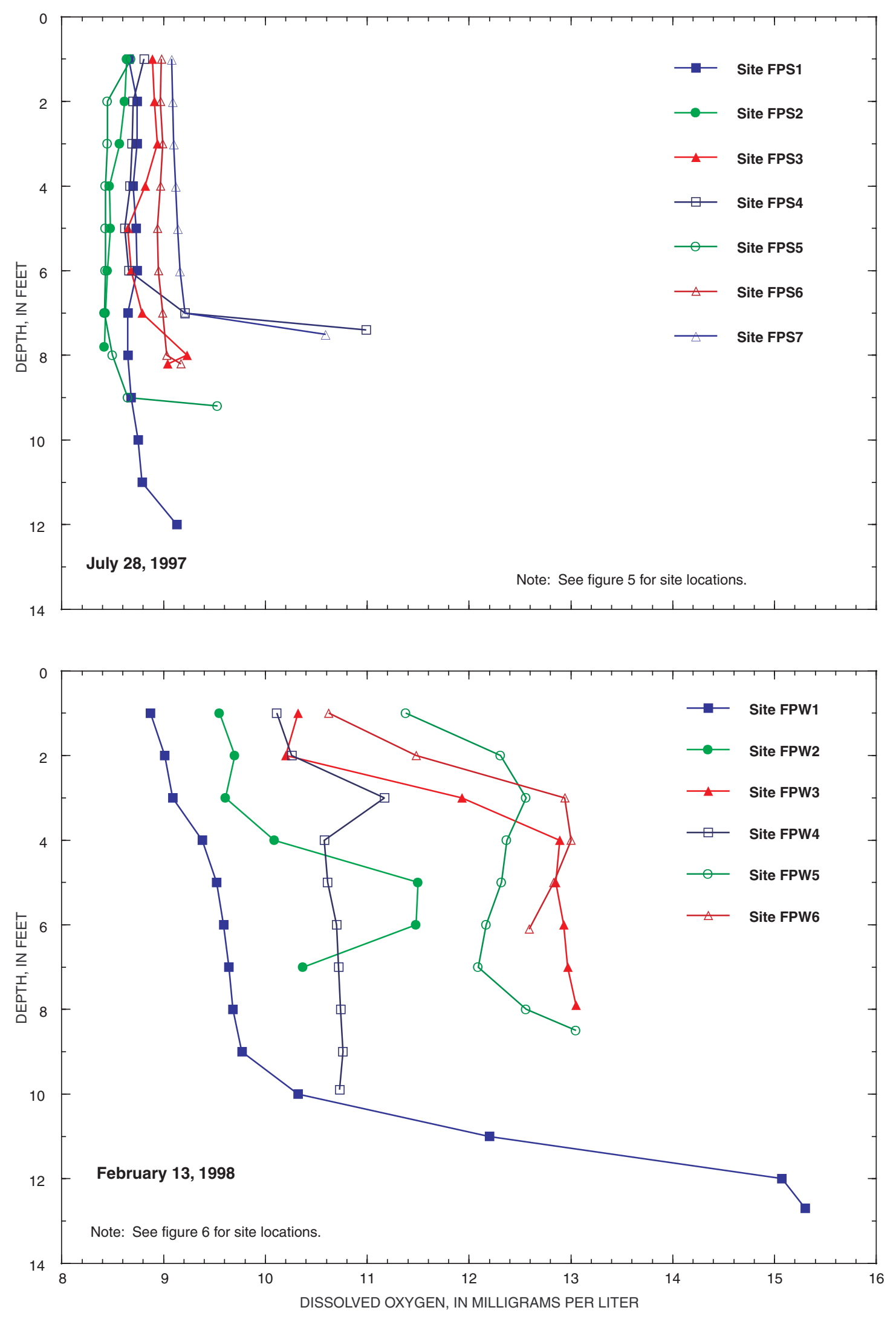

Figure 10. Dissolved-oxygen-concentration profiles in Georgetown Lake, July 28, 1997, and February 13, 1998. 
Table 6. Water-quality data for reservoir-profile samples collected from Georgetown Lake, March 11-12, 1998

[See Appendix, table A2, for the methods of analysis used for these samples; mg/L, milligrams per liter; $\mu \mathrm{g} / \mathrm{L}$, micrograms per liter; $<$, less than; see figure 2 for sampling-site locations]

\begin{tabular}{|c|c|c|c|c|c|c|c|c|c|c|c|c|c|c|c|c|c|c|c|c|c|c|c|c|c|}
\hline \multirow{2}{*}{ Profile } & \multirow{2}{*}{$\begin{array}{l}\text { Sampling } \\
\text { site }\end{array}$} & \multirow{2}{*}{$\begin{array}{l}\text { Sampling } \\
\text { date }\end{array}$} & \multirow{2}{*}{$\begin{array}{l}\text { Sample } \\
\text { depth } \\
\text { (feet) }\end{array}$} & \multirow{2}{*}{$\begin{array}{c}\text { Alka- } \\
\text { linity } \\
(\mathrm{mg} / \mathrm{L} \text { as } \\
\left.\mathrm{CaCO}_{3}\right)\end{array}$} & \multicolumn{4}{|c|}{$\begin{array}{c}\text { Dissolved cations } \\
\text { (mg/L) }\end{array}$} & \multicolumn{3}{|c|}{$\begin{array}{c}\text { Dissolved anions } \\
(\mathrm{mg} / \mathrm{L})\end{array}$} & \multirow{2}{*}{$\begin{array}{c}\text { Silica } \\
(\mathrm{mg} / \mathrm{L} \text { as } \\
\left.\mathrm{SiO}_{2}\right)\end{array}$} & \multicolumn{13}{|c|}{$\begin{array}{c}\text { Dissolved metals } \\
(\mu \mathrm{g} / \mathrm{L})\end{array}$} \\
\hline & & & & & $\mathrm{Ca}$ & Mg & K & $\mathrm{Na}$ & $\mathrm{Cl}$ & $\mathbf{F}$ & $\mathrm{SO}_{4}$ & & Al & As & Cd & $\mathrm{Cr}$ & $\mathrm{Cu}$ & $\mathrm{Fe}$ & $\mathrm{Pb}$ & Mn & $\mathbf{N i}$ & Se & $\mathbf{A g}$ & TI & $\mathrm{Zn}$ \\
\hline \multirow[t]{2}{*}{1} & SW24P1A & $03 / 12 / 98$ & 3.0 & 53 & 18.5 & 6.29 & $<2$ & 5.4 & 7.97 & 0.32 & 15.5 & 7.9 & $<40$ & $<1$ & 0.8 & $<0.8$ & $<0.8$ & 23 & $<0.8$ & 23 & $<11$ & $<1$ & $<0.2$ & $<1$ & 568 \\
\hline & SW24P1B & $03 / 12 / 98$ & 14.0 & 52 & 18.1 & 6.02 & $<2$ & 5.2 & 7.27 & 0.31 & 14.3 & 7.4 & $<40$ & $<1$ & $<0.5$ & $<0.8$ & $<0.8$ & 152 & 2.0 & 74 & $<11$ & $<1$ & $<0.2$ & $<1$ & 211 \\
\hline \multirow[t]{3}{*}{2} & SW24P2A & $03 / 12 / 98$ & 3.1 & 53 & 19.1 & 6.44 & $<2$ & 5.5 & 8.15 & 0.32 & 15.5 & 8.0 & $<40$ & $<1$ & 1.1 & $<0.8$ & $<0.8$ & 22 & $<0.8$ & 23 & $<11$ & $<1$ & $<0.2$ & $<1$ & 587 \\
\hline & SW24P2B & $03 / 12 / 98$ & 9.0 & 53 & 19.0 & 6.36 & $<2$ & 5.3 & 7.41 & 0.32 & 15.4 & 7.9 & $<40$ & $<1$ & 1.0 & $<0.8$ & $<0.8$ & 29 & $<0.8$ & 25 & $<11$ & $<1$ & $<0.2$ & $<1$ & 572 \\
\hline & SW24P2C & 03/12/98 & 12.8 & 52 & 18.5 & 6.16 & $<2$ & 5.3 & 7.19 & 0.30 & 14.0 & 8.1 & $<40$ & $<1$ & $<0.5$ & $<0.8$ & 1.5 & 253 & 3.4 & 119 & $<11$ & $<1$ & $<0.2$ & $<1$ & 176 \\
\hline \multirow[t]{2}{*}{3} & SW24P3A & 03/11/98 & 3.0 & 52 & 18.7 & 6.32 & $<2$ & 5.3 & 7.54 & 0.31 & 15.2 & 8.1 & $<40$ & $<1$ & 0.9 & $<0.8$ & $<0.8$ & 35 & $<0.8$ & 24 & $<11$ & $<1$ & $<0.2$ & $<1$ & 518 \\
\hline & SW24P3B & 03/11/98 & 6.8 & 52 & 18.9 & 6.25 & $<2$ & 5.0 & 6.67 & 0.33 & 14.8 & 7.8 & $<40$ & $<1$ & $<0.5$ & $<0.8$ & $<0.8$ & 141 & 1.0 & 28 & $<11$ & $<1$ & $<0.2$ & $<1$ & 286 \\
\hline \multirow[t]{2}{*}{4} & SW24P4A & $03 / 11 / 98$ & 3.0 & 52 & 18.9 & 6.39 & $<2$ & 5.3 & 7.47 & 0.31 & 15.3 & 8.2 & $<40$ & $<1$ & 1.0 & $<0.8$ & 1.2 & 38 & $<0.8$ & 25 & $<11$ & $<1$ & $<0.2$ & $<1$ & 529 \\
\hline & SW24P4B & $03 / 11 / 98$ & 6.4 & 52 & 18.8 & 6.27 & $<2$ & 5.1 & 6.81 & 0.31 & 14.8 & 7.9 & $<40$ & $<1$ & 0.5 & $<0.8$ & 1.1 & 125 & 1.1 & 32 & $<11$ & $<1$ & $<0.2$ & $<1$ & 240 \\
\hline \multirow[t]{3}{*}{5} & SW24P5A & $03 / 11 / 98$ & 3.1 & 52 & 19.2 & 6.47 & $<2$ & 5.6 & 8.34 & 0.31 & 15.3 & 8.3 & $<40$ & $<1$ & 1.0 & $<0.8$ & 1.0 & 40 & $<0.8$ & 26 & $<11$ & $<1$ & $<0.2$ & $<1$ & 520 \\
\hline & SW24P5B & $03 / 11 / 98$ & 3.7 & 52 & 18.1 & 6.06 & $<2$ & 4.9 & 6.67 & 0.30 & 15.1 & 8.0 & $<40$ & $<1$ & 0.6 & $<0.8$ & $<0.8$ & 82 & 0.8 & 30 & $<11$ & $<1$ & $<0.2$ & $<1$ & 315 \\
\hline & SW24P5C & 03/11/98 & 5.8 & 52 & 18.6 & 6.15 & $<2$ & 4.9 & 6.40 & 0.31 & 15.0 & 8.0 & $<40$ & $<1$ & $<0.5$ & $<0.8$ & $<0.8$ & 116 & 0.8 & 34 & $<11$ & $<1$ & $<0.2$ & $<1$ & 278 \\
\hline \multirow[t]{2}{*}{6} & SW24P6A & 03/11/98 & 3.0 & 52 & 18.7 & 6.38 & $<2$ & 5.7 & 8.64 & 0.31 & 15.3 & 8.2 & $<40$ & $<1$ & 1.1 & $<0.8$ & $<0.8$ & 29 & 0.8 & 24 & $<11$ & $<1$ & $<0.2$ & $<1$ & 529 \\
\hline & SW24P6B & $03 / 11 / 98$ & 7.0 & 52 & 18.5 & 6.18 & $<2$ & 5.1 & 7.04 & 0.31 & 14.7 & 8.0 & $<40$ & $<1$ & $<0.5$ & $<0.8$ & $<0.8$ & 119 & 1.1 & 34 & $<11$ & $<1$ & $<0.2$ & $<1$ & 228 \\
\hline
\end{tabular}

\begin{tabular}{|c|c|c|c|c|c|c|c|c|c|c|c|c|c|c|c|c|c|c|c|c|c|c|c|}
\hline \multirow[b]{2}{*}{$\stackrel{9}{1} \quad$ Profile } & \multirow[b]{2}{*}{$\begin{array}{l}\text { Sampling } \\
\text { site }\end{array}$} & \multirow[b]{2}{*}{$\begin{array}{l}\text { Sampling } \\
\text { date }\end{array}$} & \multirow{2}{*}{$\begin{array}{l}\text { Sample } \\
\text { depth } \\
\text { (feet) }\end{array}$} & \multirow{2}{*}{$\begin{array}{c}\text { Hard- } \\
\text { ness } \\
(\mathrm{mg} / \mathrm{L} \text { as } \\
\left.\mathrm{CaCO}_{3}\right)\end{array}$} & \multirow{2}{*}{$\begin{array}{c}\text { Dis- } \\
\text { solved } \\
\text { organic } \\
\text { carbon } \\
\text { (mg/L } \\
\text { as C) }\end{array}$} & \multicolumn{13}{|c|}{$\begin{array}{c}\text { Total recoverable metals } \\
(\mu \mathrm{g} / \mathrm{L})\end{array}$} & \multicolumn{3}{|c|}{$\begin{array}{l}\text { Total nutrients } \\
\text { (mg/L) }\end{array}$} & \multirow{2}{*}{$\begin{array}{c}\text { Total } \\
\text { organic } \\
\text { carbon } \\
\text { (mg/L } \\
\text { as C) }\end{array}$} & \multirow{2}{*}{$\begin{array}{l}\text { Total } \\
\text { sus- } \\
\text { pended } \\
\text { solids } \\
\text { (mg/L) }\end{array}$} \\
\hline & & & & & & Al & As & Cd & $\mathrm{Cr}$ & $\mathrm{Cu}$ & $\mathrm{Fe}$ & $\mathbf{P b}$ & Mn & $\mathrm{Ni}$ & Se & $\mathrm{Ag}$ & TI & $\mathrm{Zn}$ & $\begin{array}{l}\text { Ammonia } \\
\text { (as N) }\end{array}$ & $\begin{array}{l}\text { Nitrite } \\
\text { plus } \\
\text { nitrate } \\
\text { (as N) }\end{array}$ & $\begin{array}{l}\text { Phos- } \\
\text { phorus } \\
\text { (as P) }\end{array}$ & & \\
\hline 1 & SW24P1A & $03 / 12 / 98$ & 3.0 & 72.1 & $<1.5$ & $<40$ & $<1$ & 1.8 & $<0.8$ & 0.8 & 55 & $<0.8$ & 25 & $<11$ & $<1$ & $<0.2$ & $<1$ & 575 & $<0.05$ & 0.25 & $<0.02$ & $<1.5$ & $<4$ \\
\hline & SW24P1B & 03/12/98 & 14.0 & 70.0 & $<1.5$ & $<40$ & $<1$ & 1.0 & $<0.8$ & 1.2 & 467 & 4.5 & 84 & $<11$ & $<1$ & $<0.2$ & $<1$ & 361 & $<0.05$ & 0.13 & $<0.02$ & $<1.5$ & $<4$ \\
\hline 2 & SW24P2A & $03 / 12 / 98$ & 3.1 & 74.2 & $<1.5$ & $<40$ & $<1$ & 1.6 & $<0.8$ & 0.8 & 58 & 0.9 & 24 & $<11$ & $<1$ & $<0.2$ & $<1$ & 567 & $<0.05$ & 0.25 & $<0.02$ & $<1.5$ & $<4$ \\
\hline & SW24P2B & 03/12/98 & 9.0 & 73.6 & $<1.5$ & $<40$ & $<1$ & 1.6 & $<0.8$ & $<0.8$ & 76 & 1.1 & 27 & $<11$ & $<1$ & $<0.2$ & $<1$ & 565 & $<0.05$ & 0.21 & $<0.02$ & $<1.5$ & $<4$ \\
\hline 유 & SW24P2C & 03/12/98 & 12.8 & 71.6 & $<1.5$ & $<40$ & $<1$ & 0.8 & $<0.8$ & $<0.8$ & 773 & 8.8 & 138 & $<11$ & $<1$ & $<0.2$ & $<1$ & 300 & 0.08 & 0.07 & $<0.02$ & $<1.5$ & $<4$ \\
\hline 3 & SW24P3A & 03/11/98 & 3.0 & 72.7 & $<1.5$ & $<40$ & $<1$ & 1.6 & $<0.8$ & 0.8 & 113 & 0.9 & 28 & $<11$ & $<1$ & $<0.2$ & $<1$ & 526 & $<0.05$ & 0.19 & $<0.02$ & $<1.5$ & $<4$ \\
\hline & SW24P3B & 03/11/98 & 6.8 & 72.9 & $<1.5$ & $<40$ & $<1$ & 1.2 & $<0.8$ & $<0.8$ & 465 & 2.5 & 41 & $<11$ & $<1$ & $<0.2$ & $<1$ & 413 & 0.13 & 0.12 & $<0.02$ & $<1.5$ & $<4$ \\
\hline 4 & SW24P4A & $03 / 11 / 98$ & 3.0 & 73.5 & $<1.5$ & $<40$ & $<1$ & 1.5 & $<0.8$ & 1.3 & 123 & 1.2 & 28 & $<11$ & $<1$ & $<0.2$ & $<1$ & 517 & $<0.05$ & 0.19 & $<0.02$ & $<1.5$ & $<4$ \\
\hline & SW24P4B & 03/11/98 & 6.4 & 72.8 & $<1.5$ & $<40$ & $<1$ & 1.4 & $<0.8$ & 1.8 & 414 & 1.7 & 42 & $<11$ & $<1$ & $<0.2$ & $<1$ & 433 & $<0.05$ & 0.12 & $<0.02$ & $<1.5$ & $<4$ \\
\hline 5 & SW24P5A & 03/11/98 & 3.1 & 74.6 & $<1.5$ & $<40$ & $<1$ & 1.8 & $<0.8$ & 1.3 & 108 & $<0.8$ & 28 & $<11$ & $<1$ & $<0.2$ & $<1$ & 529 & $<0.05$ & 0.18 & $<0.02$ & $<1.5$ & $<4$ \\
\hline & SW24P5B & 03/11/98 & 3.7 & 70.2 & $<1.5$ & $<40$ & $<1$ & 1.5 & $<0.8$ & $<0.8$ & 301 & 1.3 & 37 & $<11$ & $<1$ & $<0.2$ & $<1$ & 465 & $<0.05$ & 0.13 & $<0.02$ & $<1.5$ & 52 \\
\hline & SW24P5C & 03/11/98 & 5.8 & 71.8 & $<1.5$ & $<40$ & $<1$ & 1.3 & $<0.8$ & $<0.8$ & 444 & 1.7 & 44 & $<11$ & $<1$ & $<0.2$ & $<1$ & 444 & $<0.05$ & 0.12 & $<0.02$ & $<1.5$ & $<4$ \\
\hline 6 & SW24P6A & 03/11/98 & 3.0 & 73.0 & $<1.5$ & $<40$ & $<1$ & 1.7 & $<0.8$ & 2.0 & 76 & 0.9 & 26 & $<11$ & $<1$ & $<0.2$ & $<1$ & 539 & $<0.05$ & 0.20 & $<0.02$ & $<1.5$ & $<4$ \\
\hline & SW24P6B & 03/11/98 & 7.0 & 71.6 & $<1.5$ & $<40$ & $<1$ & 1.4 & $<0.8$ & 1.4 & 417 & 1.5 & 41 & $<11$ & $<1$ & $<0.2$ & $<1$ & 426 & $<0.05$ & 0.12 & $<0.02$ & $<1.5$ & $<4$ \\
\hline
\end{tabular}




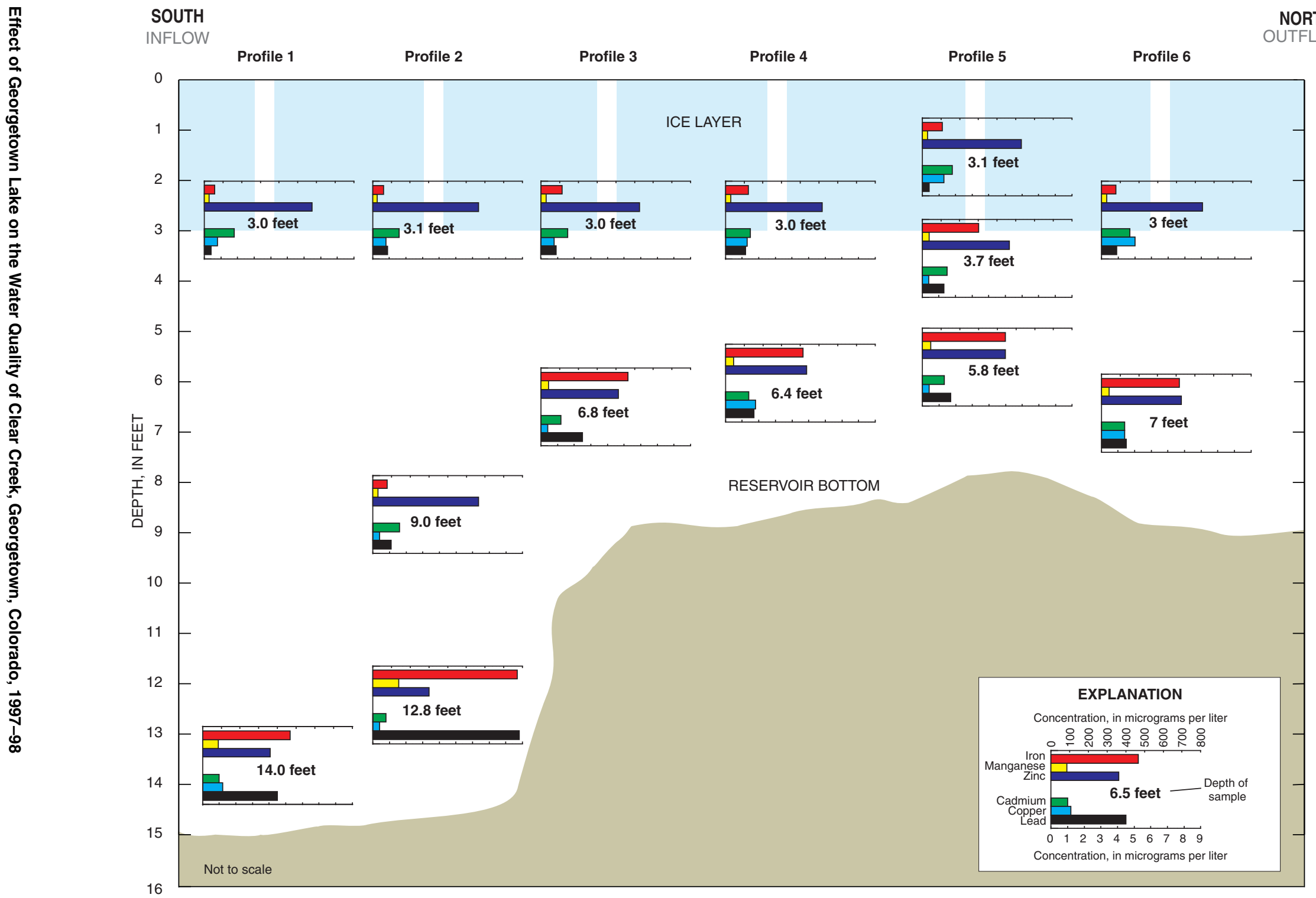

Figure 11. Total recoverable metal concentrations in Georgetown Lake water-quality-profile samples, March 11-12, 1998. 
was more representative of the water nearest the bottom of the reservoir than directly under the ice. On March 4, 1998, total recoverable iron concentrations were $61 \mu \mathrm{g} / \mathrm{L}$ in the inflow (table 8 in the "Comparison of Inflow and Outflow Water Chemistry" section) and $399 \mu \mathrm{g} / \mathrm{L}$ in the outflow (table 9 in the "Comparison of Inflow and Outflow Water Chemistry section). The profile samples had an average total recoverable iron concentration of $89 \mu \mathrm{g} / \mathrm{L}$ directly under the ice and about $497 \mu \mathrm{g} / \mathrm{L}$ nearest the reservoir bottom (table 6). Total recoverable zinc concentrations on March 4, 1998, were $530 \mu \mathrm{g} / \mathrm{L}$ in the inflow and $424 \mu \mathrm{g} / \mathrm{L}$ in the outflow. Average total recoverable zinc concentrations in profiles were $542 \mu \mathrm{g} / \mathrm{L}$ nearest the ice and $396 \mu \mathrm{g} / \mathrm{L}$ nearest the reservoir bottom. Inflow temperature was $0.9^{\circ} \mathrm{C}$ and the outflow temperature was $4.0^{\circ} \mathrm{C}$. These relations indicate that the chemical stratification of trace metals in the reservoir during March 1998 did not result from stagnation of the deeper, warmer water but resulted from photosynthesis and water/sediment interactions. These processes were sufficiently rapid to stratify the water column as the water moved relatively slowly through the reservoir.

\section{Sediment-Interface Water Chemistry}

In an attempt to determine if constituents (especially metals) were being exchanged between bed sediment and the water column, sediment-interface water samplers were installed at six sites (fig. 2; SW24B series). The samplers consisted of semipermeable, tube-shaped membranes placed inside 1.5-inchdiameter acrylic or 2-inch-diameter polyvinyl chloride tubes that were about 18 inches long, capped at each end, and drilled with 0.25 -inch holes to allow water to enter. The tubes were soaked in acidified water prior to assembly to remove any metals from their surfaces. The membranes, which had an equivalent pore-filter size of $0.002-0.003 \mu \mathrm{m}$, were filled with inorganic blank water, and the assembled samplers were stored in inorganic blank water to maintain the integrity of the membranes. To obtain sufficient sample volume, three samplers were placed in nylon-mesh bags, lowered through the ice, and laid horizontally on the reservoir bottom at each site on March 11, 1998. They were retrieved on March 23, 1998, and sent to the laboratory for analysis. Results of water-quality analyses are listed in table 7.

Table 7. Water-quality data for sediment-interface water samples collected from Georgetown Lake, March 23, 1998

[mg/L, milligrams per liter; $\mu \mathrm{g} / \mathrm{L}$, micrograms per liter; <, less than; see fig. 2 for sampling-site locations]

\begin{tabular}{|c|c|c|c|c|c|c|c|c|c|c|c|c|c|c|}
\hline \multirow{2}{*}{$\begin{array}{l}\text { Sampling } \\
\text { site }\end{array}$} & \multicolumn{5}{|c|}{$\begin{array}{l}\text { Cations } \\
\text { (mg/L) }\end{array}$} & \multicolumn{3}{|c|}{$\begin{array}{l}\text { Anions } \\
\text { (mg/L) }\end{array}$} & \multirow{2}{*}{\multicolumn{2}{|c|}{$\begin{array}{c}\text { Alkalinity } \\
(\mathrm{mg} / \mathrm{L} \text { as } \\
\left.\mathrm{CaCO}_{3}\right)\end{array}$}} & \multicolumn{4}{|c|}{$\begin{array}{c}\text { Dissolved nutrients } \\
(\mathrm{mg} / \mathrm{L})\end{array}$} \\
\hline & $\mathrm{Ca}$ & Mg & K & \multicolumn{2}{|c|}{$\mathrm{Na}$} & Cl & $\mathbf{F}$ & $\mathrm{SO}_{4}$ & & & $\begin{array}{l}\text { Ammonia } \\
\text { (as N) }\end{array}$ & \multicolumn{2}{|r|}{$\begin{array}{l}\text { Nitrate } \\
\text { (as N) }\end{array}$} & $\begin{array}{l}\text { Phosphorus } \\
\text { (as P) }\end{array}$ \\
\hline SW24B1 & 21.5 & 7.5 & $<2$ & \multicolumn{2}{|c|}{11.9} & 26.4 & 0.31 & 15.1 & \multicolumn{2}{|c|}{51} & 0.03 & \multicolumn{2}{|r|}{0.19} & $<0.005$ \\
\hline SW24B2 & 21.4 & 7.4 & $<2$ & \multicolumn{2}{|c|}{11.0} & 23.7 & 0.31 & 15.0 & \multicolumn{2}{|c|}{51} & 0.02 & \multicolumn{2}{|r|}{0.23} & $<0.005$ \\
\hline SW24B3 & 19.9 & 6.7 & $<2$ & \multicolumn{2}{|c|}{7.3} & 13.3 & 0.30 & 14.8 & \multicolumn{2}{|c|}{51} & 0.03 & \multicolumn{2}{|r|}{0.19} & $<0.005$ \\
\hline SW24B4 & 17.5 & 6.0 & $<2$ & \multicolumn{2}{|c|}{6.5} & 13.1 & 0.29 & 14.8 & \multicolumn{2}{|c|}{51} & 0.01 & \multicolumn{2}{|r|}{0.17} & $<0.005$ \\
\hline SW24B5 & 18.6 & 6.3 & $<2$ & \multicolumn{2}{|c|}{5.5} & 7.7 & 0.29 & 14.9 & \multicolumn{2}{|c|}{53} & 0.01 & \multicolumn{2}{|r|}{0.15} & $<0.005$ \\
\hline SW24B6 & 19.4 & 6.7 & $<2$ & \multicolumn{2}{|c|}{6.7} & 11.0 & 0.29 & 14.7 & \multicolumn{2}{|c|}{51} & 0.01 & \multicolumn{2}{|r|}{0.16} & $<0.005$ \\
\hline \multirow{2}{*}{$\begin{array}{l}\text { Sampling } \\
\text { site }\end{array}$} & \multicolumn{13}{|c|}{$\begin{array}{c}\text { Dissolved metals } \\
(\mu \mathrm{g} / \mathrm{L})\end{array}$} & \multirow{2}{*}{$\begin{array}{l}\text { Dissolved } \\
\text { organic } \\
\text { carbon } \\
\text { (mg/L as C) }\end{array}$} \\
\hline & Al & As & Cd & $\mathrm{Cr}$ & $\mathrm{Cu}$ & $\mathrm{Fe}$ & $\mathrm{Pb}$ & Mn & $\mathbf{N i}$ & Se & Ag & TI & $\mathrm{Zn}$ & \\
\hline SW24B1 & $<40$ & $<1$ & 1.2 & $<0.8$ & 1.5 & 22 & 0.8 & 50 & $<11$ & $<1$ & $<0.2$ & $<0.6$ & 565 & $<1.5$ \\
\hline SW24B2 & $<40$ & $<1$ & 1.4 & $<0.8$ & $<0.8$ & 30 & $<0.6$ & 44 & $<11$ & $<1$ & $<0.2$ & $<0.6$ & 573 & $<1.5$ \\
\hline SW24B3 & $<40$ & $<1$ & $<0.6$ & $<0.8$ & 0.9 & 9 & $<0.6$ & 25 & $<11$ & $<1$ & $<0.2$ & $<0.6$ & 325 & $<1.5$ \\
\hline SW24B4 & $<40$ & $<1$ & $<0.6$ & $<0.8$ & $<0.8$ & 7 & $<0.6$ & 27 & $<11$ & $<1$ & $<0.2$ & $<0.6$ & 343 & $<1.5$ \\
\hline SW24B5 & $<40$ & $<1$ & $<0.6$ & $<0.8$ & $<0.8$ & 7 & $<0.6$ & 21 & $<11$ & $<1$ & $<0.2$ & $<0.6$ & 119 & $<1.5$ \\
\hline SW24B6 & $<40$ & $<1$ & $<0.6$ & $<0.8$ & $<0.8$ & 9 & $<0.6$ & 27 & $<11$ & $<1$ & $<0.2$ & $<0.6$ & 212 & $<1.5$ \\
\hline
\end{tabular}


Comparison of dissolved metal concentrations for sediment-interface water (table 7) and dissolved metal concentrations in reservoir-profile samples (table 6) allow a few conclusions about water/ sediment interaction to be made. Interpretation is complicated by the 11- to 12-day delay between collection of the reservoir-profiles samples during March 11-12, 1998, and collection of the sedimentinterface water samples on March 23, 1998. Reservoirinflow water chemistry was changing rapidly, apparently in response to initial melting of ice and snow at lower elevations between these sampling periods.

Concentrations of dissolved iron, dissolved lead, and dissolved manganese in sediment-interface water were substantially lower than concentrations of dissolved iron, dissolved lead, and dissolved manganese in the reservoir-profile samples collected nearest the bottom (table 6). On average, dissolved iron concentration in sediment-interface water was 9 percent of the dissolved concentration in reservoirprofile samples; dissolved lead concentration was about 29 percent (assuming concentrations below the reporting limit to be one-half the reporting limit); and dissolved manganese concentration was about 70 percent. In the preceding section titled "Metals," it was concluded that downwardly increasing concentrations of total recoverable iron, total recoverable lead, and total recoverable manganese indicated that the bed sediments were a source of those metals. The fact that concentrations of dissolved iron, dissolved lead, and dissolved manganese in sediment-interface water were substantially lower than concentrations of dissolved iron, dissolved lead, and dissolved manganese in the lowermost reservoir-profile samples can be attributed to the small pore size of the membranes in the sediment-interface water samplers, which allowed entry of only (or mostly) dissolved metals. These relations indicate that most of the iron and lead contributed to the water column by the bed sediment was in colloidal or microcrystalline form. Most of contributed manganese was in dissolved form, probably a result of the greater stability of the $\mathrm{Mn}^{2+}$ ion compared to the $\mathrm{Fe}^{2+}$ ion when going from a reducing environment to an oxidizing environment.

The average concentration of dissolved zinc in the six sediment-interface water samples $(356 \mu \mathrm{g} / \mathrm{L})$ exceeded the average concentration of dissolved zinc in the six lowermost reservoir-profile samples $(237 \mu \mathrm{g} / \mathrm{L})$, a relation opposite the downwardly decreasing concentrations of dissolved and total recoverable zinc in the reservoir-profile samples. This result probably was due to slightly increased inflow of early snowmelt water into the smaller, southern pool of the reservoir a few days before the collection of the sediment-interface water samples. Sediment-interface water samples from sites SW24B1 and SW24B2 in the southern pool showed dissolved zinc concentrations of $565 \mu \mathrm{g} / \mathrm{L}$ and $573 \mu \mathrm{g} / \mathrm{L}$ (table 7), essentially equal to dissolved zinc concentrations in the reservoir-profile samples collected from uppermost sites S24P1A $(568 \mu \mathrm{g} / \mathrm{L})$ and S24P2A $(587 \mu \mathrm{g} / \mathrm{L})($ table 6$)$ but substantially higher than dissolved zinc concentrations in reservoir-profile samples collected from lowermost sites SW24P1B $(211 \mu \mathrm{g} / \mathrm{L})$ and SW24P2C (176 $\mu \mathrm{g} / \mathrm{L})$ (table 6). These relations indicate that the slightly increased inflow of early snowmelt water eliminated the chemical stratification in the southern, smaller pool that had developed under the ice during winter. The average of dissolved zinc concentrations in sediment-interface water samples collected from sites SW24B3 through SW24B6 in the larger, northern pool $(250 \mu \mathrm{g} / \mathrm{L})$ is only slightly less than the average of dissolved zinc concentrations in samples collected from the lowermost reservoir-profile sites in this pool (SW24P3B, SW24P4B, SW24P5C, and SW24P6B) $(258 \mu \mathrm{g} / \mathrm{L})$. This relation indicates that chemical stratification that had developed in the winter was less disturbed in the larger pool than in the smaller pool when the sedimentinterface samples were collected on March 23, 1998.

The lack of relatively large dissolved iron and dissolved manganese concentrations in sedimentinterface water samples indicates that reservoir water directly overlying the sediment was not in a reducing state. Small concentrations of dissolved ammonia compared to concentrations of dissolved nitrate in the samples (table 7) supports this conclusion. Reducing conditions existed beneath the surface of the sediments (as is indicated by the presence of sulfatereducing bacteria; table 4 ) but generally did not extend into the water column, probably because the flow of water through the reservoir and photosynthesis by benthic plants kept the water oxygenated (fig. 10). 


\section{EFFECT OF GEORGETOWN LAKE ON WATER QUALITY OF CLEAR CREEK}

Water-quality samples for the reservoir inflow were collected at site SW24U about $50 \mathrm{ft}$ upstream from the reservoir inflow (fig. 2). This site was selected to include the discharge from Silver Gulch. The samples were collected from a relatively uniform stream cross section that was a sufficient distance downstream from Silver Gulch to ensure mixing. Reservoir-outflow samples were collected at site SW24L about $50 \mathrm{ft}$ downstream from the base of the reservoir spillway (fig. 2). These samples were collected weekly during periods of rapidly changing discharge (generally mid-April through September) and biweekly to monthly during base flow (generally October through mid-April).

Water-quality samples were collected from the reservoir inflow and outflow by using a plastic $\mathrm{DH}-81$ instream sampler. Samples were transferred from the DH-81 into a churn splitter and special precautions taken to minimize the introduction of airborne particles into the sample.

The first two reservoir-outflow samples (site SW24L) were collected using the equal-widthincrement method; however, because of safety concerns, subsequent samples were collected from the spillway with a DH-81 sampler after field measurements indicated that the water was well mixed.

Iron-speciation samples were collected from the inflow and outflow over a 16-hour period of day and night to determine the effect of photosynthesis (by altering $\mathrm{pH}$ and concentrations of dissolved oxygen) on iron transport through the reservoir. Twelve samples from the inflow and 12 samples from the outflow were analyzed using a portable spectrophotometer. Field measurements also were made at the time of sample collection.

\section{Comparison of Inflow and Outflow Water Chemistry}

Results of the year-long sampling of inflow (table 8) and outflow (table 9) water show that Georgetown Lake alters the quality of inflow water. This section describes the effects of Georgetown Lake on field measurements, trace metals, and nutrients.

\section{Field Measurements}

The reservoir increases the temperature of the water (fig. 12) throughout most of the year by exposing it to sunlight and insulating it from cold air with an ice cover during winter. Specific conductance (fig. 12) remained essentially unchanged as water flowed through the reservoir. It increased steadily from August 1997 until it peaked in late April 1998, coinciding with the initial increase in discharge (fig. 3) due to spring snowmelt. Specific conductance was smallest during high discharge in late June 1998, after which it began to increase again. The substantially greater specific conductance of inflow water compared to outflow water on April 27, 1998, when average residence time was about 9 days (figs. 3 and 4), occurred during initial snowmelt runoff. During the 1-year sampling period, outflow water usually had higher $\mathrm{pH}$ than inflow water (fig. 12) because of photosynthetic consumption of carbon dioxide gas in the reservoir. Outflow $\mathrm{pH}$ generally exceeded 8.5 on two occasions: (1) during late August through October 1997 after discharge had decreased substantially, allowing water to remain longer in the reservoir and be substantially affected by photosynthesis, and (2) during April through mid-May 1998, when early snowmelt flushed nutrients into the reservoir. Dissolved-oxygen concentrations (fig. 12) in inflow and outflow water generally were largest when water temperatures were lowest. Dissolved-oxygen concentrations in the outflow did not exceed concentrations in the inflow in 18 of 31 measurements taken on the same day despite the production of dissolved oxygen in the reservoir, possibly because oxygen exsolved from the outflow water as it flowed over the spillway and $50 \mathrm{ft}$ downstream before measurement.

\section{Metals}

Data for the year-long water-quality sampling of inflow to and outflow from Georgetown Lake are listed in tables 8 and 9. Concentrations of arsenic, selenium, and thallium were less than the reporting limit for all 66 samples; chromium, nickel, and silver were detected in only a few samples. Therefore, no conclusion about the behavior of these six metals in Georgetown Lake can be made. The remaining metals that were analyzed-aluminum, cadmium, copper, iron, lead, manganese, and zinc - were detected in 
Table 8. Water-quality data for samples collected from the Georgetown Lake inflow, site SW24U, 1997-98

$\left[{ }^{\circ} \mathrm{C}\right.$, degrees Celsius; $\mu \mathrm{S} / \mathrm{cm}$, microsiemens per centimeter at 25 degrees Celsius; $\mathrm{mg} / \mathrm{L}$, milligrams per liter; $\mu \mathrm{g} / \mathrm{L}$, micrograms per liter; <, less than; ,-- no data; see figure 2 for location of site SW24U]

\begin{tabular}{|c|c|c|c|c|c|c|c|c|c|c|c|c|c|}
\hline \multirow{2}{*}{$\begin{array}{l}\text { Sampling } \\
\text { date }\end{array}$} & \multirow{2}{*}{$\begin{array}{c}\text { Water } \\
\text { temperature } \\
\left({ }^{\circ} \mathbf{C}\right)\end{array}$} & \multirow{2}{*}{$\begin{array}{c}\text { Specific } \\
\text { conductance } \\
(\mu \mathrm{S} / \mathrm{cm})\end{array}$} & \multirow{2}{*}{$\mathrm{pH}$} & \multirow{2}{*}{$\begin{array}{l}\text { Dissolved } \\
\text { oxygen } \\
\text { (mg/L) }\end{array}$} & \multirow{2}{*}{$\begin{array}{c}\text { Alkalinity } \\
\text { (mg/L as } \\
\left.\mathrm{CaCO}_{3}\right)\end{array}$} & \multicolumn{4}{|c|}{$\begin{array}{c}\text { Dissolved cations } \\
(\mathrm{mg} / \mathrm{L})\end{array}$} & \multicolumn{3}{|c|}{$\begin{array}{c}\text { Dissolved anions } \\
\text { (mg/L) }\end{array}$} & \multirow{2}{*}{$\begin{array}{l}\text { Dissolved } \\
\text { silica } \\
(\mathrm{mg} / \mathrm{L} \text { as } \\
\left.\mathrm{SiO}_{2}\right)\end{array}$} \\
\hline & & & & & & $\mathrm{Ca}$ & Mg & $\mathrm{K}$ & $\mathrm{Na}$ & $\mathrm{Cl}$ & $\mathbf{F}$ & $\mathrm{SO}_{4}$ & \\
\hline $08 / 14 / 97$ & 10.1 & 85 & 8.0 & 8.1 & 33 & 10.8 & 2.9 & $<2$ & 1.9 & 1.4 & 0.20 & 6.6 & 6.1 \\
\hline 08/20/97 & 10.0 & 89 & 7.2 & 8.2 & 33 & 11.5 & 3.3 & $<2$ & 2.2 & 1.5 & $<0.20$ & 6.6 & 6.4 \\
\hline 08/27/97 & 11.2 & 91 & 8.4 & 8.1 & 35 & 12.1 & 3.5 & $<2$ & 2.4 & 1.6 & 0.20 & 6.8 & 6.3 \\
\hline 09/05/97 & 12.0 & 97 & 8.1 & 7.1 & 36 & 13.0 & 3.7 & $<2$ & 2.6 & 2.2 & 0.31 & 8.8 & 6.5 \\
\hline 09/12/97 & 12.0 & 101 & 8.4 & 8.1 & 37 & 13.5 & 4.0 & $<2$ & 2.8 & 2.5 & 0.31 & 9.3 & 5.9 \\
\hline 09/19/97 & 10.0 & 102 & 8.0 & 8.8 & 39 & 13.0 & 4.2 & $<2$ & 2.7 & 1.9 & 0.22 & 8.5 & 6.3 \\
\hline 09/24/97 & 7.5 & 103 & 8.3 & 9.2 & 41 & 13.3 & 4.3 & $<2$ & 2.9 & 2.2 & 0.21 & 8.7 & 5.9 \\
\hline 09/30/97 & 7.8 & 107 & 7.5 & 10.2 & 42 & 13.8 & 4.5 & $<2$ & 2.8 & 2.1 & 0.22 & 9.1 & 7.0 \\
\hline $10 / 10 / 97$ & 5.0 & 114 & 7.6 & 9.1 & 43 & 14.4 & 4.4 & $<2$ & 2.9 & 2.3 & 0.25 & 10 & 7.5 \\
\hline $10 / 23 / 97$ & 3.3 & 119 & 8.2 & 9.2 & 46 & 16.0 & 5.0 & $<2$ & 3.4 & 3.1 & 0.27 & 12 & 7.8 \\
\hline $11 / 06 / 97$ & 3.6 & 124 & 8.1 & 9.4 & 45 & 16.2 & 4.9 & $<2$ & 3.6 & 3.4 & 0.26 & 12 & 7.4 \\
\hline $12 / 04 / 97$ & 1.7 & 140 & 7.8 & 11.3 & 48 & 17.0 & 5.3 & $<2$ & 4.1 & 4.2 & 0.32 & 14 & 7.8 \\
\hline 01/08/98 & 0.0 & 149 & 8.1 & 9.4 & 49 & 17.6 & 5.6 & $<2$ & 3.9 & 4.0 & 0.30 & 14 & 7.3 \\
\hline 02/06/98 & 2.0 & 160 & 8.1 & 10.1 & 49 & 18.5 & 5.8 & $<2$ & 4.6 & 5.4 & 0.31 & 14 & 8.1 \\
\hline 03/04/98 & 0.9 & 170 & 7.9 & 11.0 & 51 & 18.2 & 6.1 & $<2$ & 5.2 & 7.4 & 0.31 & 14 & 6.9 \\
\hline 04/01/98 & 1.8 & 210 & 8.6 & 10.6 & 54 & 22 & 7.3 & 1.1 & 8.8 & 23 & 0.36 & 19 & -- \\
\hline 04/13/98 & 3.0 & 204 & 8.5 & 9.8 & 52 & 19 & 6.4 & 1.3 & 9.4 & 22 & 0.35 & 18 & -- \\
\hline $04 / 27 / 98$ & 4.4 & 246 & 8.2 & 9.6 & 52 & 23 & 7.7 & 1.3 & 14 & 43 & 0.30 & 19 & -- \\
\hline 05/04/98 & 5.0 & 199 & 8.3 & 9.3 & 48 & 19 & 6.1 & 1.0 & 12 & 30 & 0.29 & 14 & -- \\
\hline 05/11/98 & 5.0 & 176 & 8.2 & 9.3 & 42 & 16 & 5.1 & 0.9 & 8.9 & 21 & 0.30 & 12 & -- \\
\hline 05/18/98 & 7.5 & 124 & 8.3 & -- & 44 & 13 & 4.0 & 0.8 & 5.8 & 11 & 0.23 & 10 & -- \\
\hline $05 / 26 / 98$ & 7.5 & 100 & 8.2 & 11.0 & 34 & 11 & 3.4 & 0.6 & 3.9 & 6.7 & 0.21 & 8 & -- \\
\hline 06/01/98 & 6.6 & 77 & 7.7 & 8.6 & 34 & 9.0 & 2.6 & 0.6 & 2.7 & 4.3 & 0.19 & 7 & -- \\
\hline 06/08/98 & 6.0 & 86 & 7.5 & 10.5 & 28 & 10 & 3.0 & 0.9 & 3.1 & 4.7 & 0.20 & 7 & -- \\
\hline $06 / 17 / 98$ & 7.0 & 83 & 7.8 & 9.0 & 30 & 9.5 & 2.7 & 1.2 & 2.5 & 3.9 & 0.21 & 7 & -- \\
\hline $06 / 22 / 98$ & 7.5 & 72 & 7.9 & 9.5 & 26 & 9.0 & 2.5 & 0.9 & 2.2 & 3.1 & 0.13 & 6 & -- \\
\hline 06/29/98 & 6.3 & 63 & 7.8 & 9.0 & 24 & 7.6 & 2.2 & 0.7 & 1.8 & 2.3 & 0.21 & 5 & -- \\
\hline 07/06/98 & 9.0 & 68 & 7.9 & 8.6 & 28 & 8.4 & 2.3 & 0.8 & 1.8 & 2.1 & 0.16 & 5 & -- \\
\hline 07/13/98 & 9.0 & 68 & 7.9 & 8.5 & 24 & 9.3 & 2.5 & 0.9 & 1.9 & 2.2 & 0.16 & 6 & -- \\
\hline 07/20/98 & 14.5 & 75 & 8.0 & 8.6 & 28 & 10 & 2.7 & 0.6 & 2.0 & 2.2 & 0.18 & 7 & -- \\
\hline $07 / 27 / 98$ & 12.0 & 85 & 7.8 & 7.8 & 30 & 11 & 2.9 & 0.8 & 2.4 & 2.6 & 0.21 & 7 & -- \\
\hline 08/03/98 & 9.8 & 85 & 7.7 & 8.2 & 32 & 12 & 3.2 & 0.6 & 2.5 & 2.4 & 0.21 & 8 & -- \\
\hline 08/10/98 & 12.0 & 90 & 8.0 & 7.8 & 32 & 12 & 3.2 & $<0.5$ & 2.6 & 3.0 & 0.23 & 9 & -- \\
\hline
\end{tabular}


Table 8. Water-quality data for samples collected from the Georgetown Lake inflow, site SW24U, 1997-98-Continued

$\left[{ }^{\circ} \mathrm{C}\right.$, degrees Celsius; $\mu \mathrm{S} / \mathrm{cm}$, microsiemens per centimeter at 25 degrees Celsius; $\mathrm{mg} / \mathrm{L}$, milligrams per liter; $\mu \mathrm{g} / \mathrm{L}$, micrograms per liter; <, less than; ,-- no data; see figure 2 for location of site SW24U]

\begin{tabular}{|c|c|c|c|c|c|c|c|c|c|c|c|c|c|c|c|}
\hline \multirow{2}{*}{$\begin{array}{l}\text { Sampling } \\
\text { date }\end{array}$} & \multicolumn{13}{|c|}{$\begin{array}{c}\text { Dissolved metals } \\
(\mu \mathrm{g} / \mathrm{L})\end{array}$} & \multirow{2}{*}{$\begin{array}{l}\text { Hardness } \\
(\mathrm{mg} / \mathrm{L} \text { as } \\
\left.\mathrm{CaCO}_{3}\right)\end{array}$} & \multirow{2}{*}{$\begin{array}{c}\text { Disolved } \\
\text { organic } \\
\text { carbon } \\
\text { (mg/L } \\
\text { as C) }\end{array}$} \\
\hline & Al & As & Cd & $\mathrm{Cr}$ & $\mathrm{Cu}$ & $\mathrm{Fe}$ & $\mathrm{Pb}$ & $\mathrm{Mn}$ & $\mathrm{Ni}$ & Se & $\mathbf{A g}$ & TI & $\mathrm{Zn}$ & & \\
\hline $08 / 14 / 97$ & $<40$ & $<1$ & 0.6 & $<0.8$ & 0.8 & $<5$ & $<0.8$ & 12 & $<11$ & $<1$ & $<0.2$ & $<1$ & 143 & 38.9 & $<1.5$ \\
\hline 08/20/97 & $<40$ & $<1$ & 0.6 & $<0.8$ & 1.0 & 28 & $<0.8$ & 14 & $<11$ & $<1$ & $<0.2$ & $<1$ & 180 & 42.2 & $<1.5$ \\
\hline $08 / 27 / 97$ & $<40$ & $<1$ & 1.0 & $<0.8$ & 0.9 & 32 & 1.8 & 18 & $<11$ & $<1$ & $<0.2$ & $<1$ & 204 & 44.5 & $<1.5$ \\
\hline 09/05/97 & $<40$ & $<50$ & $<0.5$ & $<4$ & $<0.8$ & 34 & $<0.8$ & 19 & $<11$ & $<40$ & $<6$ & $<50$ & 215 & 47.9 & $<1.5$ \\
\hline $09 / 12 / 97$ & $<40$ & $<50$ & $<0.5$ & $<4$ & $<0.8$ & 34 & $<0.8$ & 19 & $<11$ & $<40$ & $<6$ & $<50$ & 257 & 50.1 & $<1.5$ \\
\hline 09/19/97 & $<40$ & $<50$ & 0.5 & $<4$ & $<0.8$ & 31 & $<0.8$ & 19 & $<11$ & $<40$ & $<6$ & $<50$ & 276 & 49.6 & $<1.5$ \\
\hline $09 / 24 / 97$ & $<40$ & $<50$ & $<0.5$ & $<4$ & 0.9 & 33 & $<0.8$ & 21 & $<11$ & $<40$ & $<6$ & $<50$ & 294 & 50.8 & $<1.5$ \\
\hline 09/30/97 & $<40$ & $<50$ & 0.5 & $<4$ & $<0.8$ & 27 & $<0.8$ & 20 & $<11$ & $<40$ & $<6$ & $<50$ & 314 & 52.9 & $<1.5$ \\
\hline $10 / 10 / 97$ & $<40$ & $<50$ & 0.6 & $<4$ & $<0.8$ & 17 & $<0.8$ & 20 & $<11$ & $<40$ & $<6$ & $<50$ & 314 & 54.0 & $<1.5$ \\
\hline $10 / 23 / 97$ & $<40$ & $<50$ & 0.8 & $<4$ & $<0.8$ & 23 & $<0.8$ & 26 & $<11$ & $<40$ & $<6$ & $<50$ & 418 & 60.7 & $<1.5$ \\
\hline $11 / 06 / 97$ & $<40$ & $<50$ & 0.9 & $<4$ & $<0.8$ & 30 & $<0.8$ & 23 & $<11$ & $<40$ & $<6$ & $<50$ & 410 & 60.7 & $<1.5$ \\
\hline $12 / 04 / 97$ & $<40$ & $<50$ & 1.4 & $<4$ & $<0.8$ & 39 & $<0.8$ & 34 & $<11$ & $<40$ & $<6$ & $<50$ & 485 & 64.1 & $<1.5$ \\
\hline 01/08/98 & $<40$ & $<50$ & 1.3 & $<4$ & $<0.8$ & 21 & $<0.8$ & 22 & $<11$ & $<40$ & $<6$ & $<50$ & 537 & 67.0 & $<1.5$ \\
\hline 02/06/98 & $<40$ & $<50$ & 1.0 & $<4$ & $<0.8$ & 19 & 0.8 & 19 & $<11$ & $<40$ & $<6$ & $<50$ & 501 & 70.2 & $<1.5$ \\
\hline 03/04/98 & $<40$ & $<50$ & 1.4 & 4 & $<0.8$ & 21 & $<0.8$ & 19 & $<11$ & $<40$ & $<6$ & $<50$ & 523 & 70.6 & $<1.5$ \\
\hline 04/01/98 & $<45$ & $<5$ & 2.0 & $<5$ & $<1$ & 20 & $<1$ & 18 & $<1$ & $<5$ & $<0.1$ & $<1$ & 600 & 85.0 & $<1$ \\
\hline 04/13/98 & $<45$ & $<5$ & ${ }^{1} 1.6$ & $<5$ & $<2$ & 22 & $<1$ & 20 & $<10$ & $<2$ & $<0.2$ & $<1$ & 517 & 73.9 & 4 \\
\hline $04 / 27 / 98$ & $<45$ & $<5$ & 2.4 & $<5$ & $<1$ & 10 & $<1$ & 29 & $<5$ & $<5$ & $<0.1$ & $<1$ & 780 & 89.1 & 2 \\
\hline 05/04/98 & $<45$ & $<5$ & 1.7 & $<5$ & 1 & 20 & $<1$ & 25 & $<5$ & $<5$ & $<0.1$ & $<1$ & 600 & 72.6 & 3 \\
\hline 05/11/98 & $<45$ & $<5$ & 1.4 & $<5$ & 2 & 40 & $<1$ & 18 & $<1$ & $<5$ & $<0.1$ & $<1$ & 480 & 61.0 & 3 \\
\hline 05/18/98 & $<45$ & $<5$ & 0.9 & $<5$ & 1 & 40 & $<1$ & 15 & $<1$ & $<5$ & $<0.1$ & $<1$ & 320 & 48.9 & 3 \\
\hline $05 / 26 / 98$ & $<45$ & $<5$ & 0.8 & $<5$ & 2 & 40 & $<1$ & 17 & $<1$ & $<5$ & $<0.1$ & $<1$ & 230 & 41.5 & 3 \\
\hline 06/01/98 & 46 & $<1$ & 0.7 & $<5$ & 2 & 30 & 2 & 15 & $<1$ & $<5$ & $<0.1$ & $<1$ & 160 & 33.2 & 5 \\
\hline 06/08/98 & $<45$ & $<1$ & 0.6 & $<5$ & $<1$ & 30 & $<1$ & 12 & $<1$ & $<5$ & $<0.1$ & $<1$ & 170 & 37.3 & 3 \\
\hline 06/17/98 & $<45$ & $<5$ & 0.5 & $<5$ & $<1$ & 30 & $<1$ & 7 & $<5$ & $<5$ & $<0.1$ & $<1$ & 160 & 34.8 & 5 \\
\hline $06 / 22 / 98$ & $<45$ & $<5$ & 0.4 & $<5$ & $<1$ & 30 & $<1$ & 6 & $<5$ & $<5$ & $<0.1$ & $<1$ & 130 & 32.8 & 3 \\
\hline 06/29/98 & $<45$ & $<5$ & 0.4 & $<5$ & $<1$ & 20 & $<1$ & 6 & $<5$ & $<5$ & $<0.1$ & $<1$ & 100 & 28.0 & 4 \\
\hline 07/06/98 & $<45$ & $<5$ & 0.4 & $<5$ & $<1$ & 20 & $<1$ & 6 & $<5$ & $<5$ & $<0.1$ & $<1$ & 120 & 30.5 & 4 \\
\hline 07/13/98 & $<45$ & $<5$ & 0.4 & $<5$ & $<1$ & 30 & $<1$ & 7 & $<5$ & $<5$ & $<0.1$ & $<1$ & 120 & 33.5 & $<1$ \\
\hline 07/20/98 & $<45$ & $<5$ & 0.5 & $<5$ & $<1$ & 20 & $<1$ & 9 & $<5$ & $<5$ & $<0.1$ & $<1$ & 150 & 36.1 & 7 \\
\hline $07 / 27 / 98$ & $<45$ & $<5$ & 0.5 & $<5$ & $<1$ & 30 & $<1$ & 10 & $<5$ & $<5$ & $<0.1$ & $<1$ & 140 & 39.4 & 8 \\
\hline 08/03/98 & $<45$ & $<5$ & 0.4 & $<5$ & $<1$ & 30 & $<1$ & 10 & $<5$ & $<5$ & $<0.1$ & $<1$ & 150 & 43.1 & -- \\
\hline 08/10/98 & $<45$ & $<5$ & 0.5 & $<5$ & $<1$ & 30 & $<1$ & 13 & $<5$ & $<5$ & $<0.1$ & $<1$ & 180 & 43.1 & 2 \\
\hline
\end{tabular}


Table 8. Water-quality data for samples collected from the Georgetown Lake inflow, site SW24U, 1997-98-Continued

$\left[{ }^{\circ} \mathrm{C}\right.$, degrees Celsius; $\mu \mathrm{S} / \mathrm{cm}$, microsiemens per centimeter at 25 degrees Celsius; $\mathrm{mg} / \mathrm{L}$, milligrams per liter; $\mu \mathrm{g} / \mathrm{L}$, micrograms per liter; <, less than; ,-- no data; see figure 2 for location of site SW24U]

\begin{tabular}{|c|c|c|c|c|c|c|c|c|c|c|c|c|c|c|c|c|c|c|}
\hline \multirow[b]{2}{*}{$\begin{array}{l}\text { Sampling } \\
\text { date }\end{array}$} & \multicolumn{13}{|c|}{$\begin{array}{c}\text { Total recoverable metals } \\
(\mu \mathrm{g} / \mathrm{L})\end{array}$} & \multicolumn{3}{|c|}{$\begin{array}{l}\text { Total nutrients } \\
\text { (mg/L) }\end{array}$} & \multirow{2}{*}{$\begin{array}{c}\text { Total } \\
\text { organic } \\
\text { carbon } \\
\text { (mg/L } \\
\text { as C) }\end{array}$} & \multirow{2}{*}{$\begin{array}{c}\text { Total } \\
\text { sus- } \\
\text { pended } \\
\text { solids } \\
\text { (mg/L) }\end{array}$} \\
\hline & Al & As & Cd & $\mathrm{Cr}$ & $\mathrm{Cu}$ & $\mathrm{Fe}$ & $\mathrm{Pb}$ & Mn & $\mathrm{Ni}$ & Se & $\mathbf{A g}$ & $\mathrm{TI}$ & $\mathrm{Zn}$ & $\begin{array}{l}\text { Ammonia } \\
\text { (as N) }\end{array}$ & $\begin{array}{c}\text { Nitrite } \\
\text { plus } \\
\text { nitrate } \\
\text { (as N) }\end{array}$ & $\begin{array}{l}\text { Phos- } \\
\text { phorus } \\
\text { (as P) }\end{array}$ & & \\
\hline $08 / 14 / 97$ & 64 & $<1$ & 0.8 & $<0.8$ & 1.5 & 105 & 1.3 & 15 & $<11$ & $<1$ & $<0.2$ & $<1$ & 159 & $<0.05$ & 0.09 & $<0.02$ & $<1.5$ & $<4$ \\
\hline 08/20/97 & 71 & $<1$ & 0.9 & $<0.8$ & 1.4 & 128 & 1.6 & 18 & $<11$ & $<1$ & $<0.2$ & $<1$ & 186 & $<0.05$ & 0.08 & $<0.02$ & $<1.5$ & $<4$ \\
\hline $08 / 27 / 97$ & 127 & $<1$ & 0.7 & $<0.8$ & 2.0 & 377 & 4.0 & 36 & $<11$ & $<1$ & $<0.2$ & $<1$ & 199 & $<0.05$ & 0.05 & $<0.02$ & $<1.5$ & $<4$ \\
\hline 09/05/97 & 70 & $<50$ & $<0.5$ & $<4$ & 1.1 & 149 & 2.2 & 24 & $<11$ & $<40$ & $<6$ & $<50$ & 228 & $<0.05$ & 0.14 & $<0.02$ & $<1.5$ & $<4$ \\
\hline 09/12/97 & $<40$ & $<50$ & 0.6 & 4 & 0.8 & 158 & 1.6 & 24 & $<11$ & $<40$ & $<6$ & $<50$ & 274 & $<0.05$ & 0.10 & 0.10 & $<1.5$ & $<4$ \\
\hline 09/19/97 & $<40$ & $<50$ & 0.5 & $<4$ & 0.8 & 98 & 1.3 & 23 & $<11$ & $<40$ & $<6$ & $<50$ & 281 & $<0.05$ & 0.09 & 0.03 & $<1.5$ & $<4$ \\
\hline $09 / 24 / 97$ & $<40$ & $<50$ & 0.6 & $<4$ & 0.9 & 107 & 1.3 & 24 & $<11$ & $<40$ & $<6$ & $<50$ & 302 & $<0.05$ & 0.13 & 0.03 & $<1.5$ & $<4$ \\
\hline 09/30/97 & $<40$ & $<50$ & 0.7 & $<4$ & 1.0 & 92 & 1.4 & 23 & $<11$ & $<40$ & $<6$ & $<50$ & 324 & $<0.05$ & 0.11 & 0.03 & $<1.5$ & $<4$ \\
\hline $10 / 10 / 97$ & $<40$ & $<50$ & 0.9 & $<4$ & 0.8 & 86 & 1.6 & 23 & $<11$ & $<40$ & $<6$ & $<50$ & 322 & $<0.05$ & 0.13 & $<0.02$ & $<1.5$ & $<4$ \\
\hline $10 / 23 / 97$ & 40 & $<50$ & 1.1 & $<4$ & 1.1 & 106 & 2.8 & 30 & $<11$ & $<40$ & $<6$ & $<50$ & 428 & $<0.05$ & 0.17 & $<0.02$ & $<1.5$ & $<4$ \\
\hline $11 / 06 / 97$ & $<40$ & $<50$ & 1.0 & $<4$ & 1.0 & 108 & 1.7 & 26 & $<11$ & $<40$ & $<6$ & $<50$ & 411 & $<0.05$ & 0.19 & $<0.02$ & $<1.5$ & $<4$ \\
\hline $12 / 04 / 97$ & 252 & $<50$ & 2.1 & $<4$ & 2.0 & 377 & 18 & 48 & $<11$ & $<40$ & $<6$ & $<50$ & 544 & $<0.05$ & 0.19 & 0.02 & $<1.5$ & 17 \\
\hline $01 / 08 / 98$ & $<40$ & $<50$ & 1.5 & 7 & $<0.8$ & 72 & 1.3 & 24 & $<11$ & $<40$ & $<6$ & $<50$ & 540 & $<0.05$ & 0.23 & $<0.02$ & $<1.5$ & $<4$ \\
\hline $02 / 06 / 98$ & $<40$ & $<50$ & 1.7 & $<4$ & $<0.8$ & 43 & 0.8 & 21 & $<11$ & $<40$ & $<6$ & $<50$ & 505 & $<0.05$ & 0.20 & $<0.02$ & $<1.5$ & $<4$ \\
\hline 03/04/98 & $<40$ & $<50$ & 1.7 & $<4$ & $<0.8$ & 61 & 1.1 & 22 & $<11$ & $<40$ & $<6$ & $<50$ & 530 & $<0.05$ & 0.22 & $<0.02$ & $<1.5$ & $<4$ \\
\hline 04/01/98 & $<45$ & $<5$ & 1.9 & $<5$ & 2 & 80 & 2 & 24 & $<5$ & -- & $<0.1$ & $<1$ & 600 & $<0.2$ & 0.25 & $<0.02$ & $<1$ & $<5$ \\
\hline $04 / 13 / 98$ & 43 & $<5$ & 1.7 & $<5$ & $<2$ & 76 & $<1$ & 22 & $<10$ & -- & $<0.2$ & $<1$ & 556 & $<0.05$ & 0.25 & $<0.02$ & 3 & $<4$ \\
\hline $04 / 27 / 98$ & 80 & $<5$ & 2.4 & $<5$ & $<1$ & 140 & 1 & 37 & $<5$ & -- & $<0.1$ & $<1$ & 830 & $<0.2$ & $<0.05$ & 0.01 & 2 & $<5$ \\
\hline 05/04/98 & 140 & $<5$ & 2.0 & $<5$ & 2 & 310 & 3 & 37 & $<5$ & -- & $<0.1$ & $<1$ & 580 & $<0.2$ & 0.16 & 0.01 & 3 & 6 \\
\hline $05 / 11 / 98$ & 130 & $<5$ & 1.4 & $<5$ & 2 & 260 & 2 & 27 & $<5$ & -- & $<0.1$ & $<1$ & 470 & $<0.2$ & $<0.05$ & 0.05 & 3 & 8 \\
\hline 05/18/98 & 120 & $<5$ & 0.9 & $<5$ & 2 & 240 & 2 & 22 & $<5$ & -- & $<0.1$ & $<1$ & 320 & $<0.2$ & $<0.05$ & 0.03 & 4 & 6 \\
\hline $05 / 26 / 98$ & 100 & $<5$ & 0.7 & $<5$ & 3 & 170 & 3 & 23 & $<5$ & -- & $<0.1$ & $<1$ & 230 & $<0.2$ & $<0.05$ & 0.01 & 7 & $<5$ \\
\hline 06/01/98 & 150 & $<5$ & 0.6 & $<5$ & 3 & 240 & 6 & 24 & $<5$ & -- & 0.1 & $<1$ & 160 & $<0.2$ & $<0.05$ & 0.02 & 3 & $<5$ \\
\hline 06/08/98 & 80 & $<5$ & 0.5 & $<5$ & 1 & 130 & 2 & 16 & $<5$ & -- & $<0.1$ & $<1$ & 170 & $<0.2$ & $<0.05$ & 0.01 & 3 & $<5$ \\
\hline $06 / 17 / 98$ & 72 & $<5$ & 0.7 & $<5$ & $<1$ & 120 & 1 & 13 & $<5$ & -- & $<0.1$ & $<1$ & 160 & $<0.2$ & $<0.05$ & 0.02 & 2 & $<5$ \\
\hline $06 / 22 / 98$ & 70 & $<5$ & 0.4 & $<5$ & $<1$ & 110 & $<1$ & 9 & $<5$ & -- & $<0.1$ & $<1$ & 130 & $<0.2$ & 0.10 & 0.02 & 3 & $<5$ \\
\hline $06 / 29 / 98$ & 83 & $<5$ & 0.4 & $<5$ & $<1$ & 160 & 2 & 13 & $<5$ & $<5$ & $<0.1$ & $<1$ & 110 & $<0.2$ & 0.10 & 0.02 & 4 & 6 \\
\hline 07/06/98 & 57 & $<5$ & 0.3 & $<5$ & $<1$ & 160 & $<1$ & 10 & $<5$ & $<5$ & $<0.1$ & $<1$ & 120 & $<0.2$ & 0.10 & $<0.01$ & 3 & $<5$ \\
\hline 07/13/98 & 53 & $<5$ & 0.4 & $<5$ & 1 & 150 & 2 & 14 & $<5$ & $<5$ & $<0.1$ & $<1$ & 120 & $<0.2$ & 0.12 & $<0.01$ & 6 & $<5$ \\
\hline $07 / 20 / 98$ & $<45$ & $<5$ & 0.4 & $<5$ & $<1$ & 80 & 1 & 12 & $<5$ & $<5$ & $<0.1$ & $<1$ & 140 & $<0.2$ & 0.11 & $<0.01$ & 5 & $<5$ \\
\hline $07 / 27 / 98$ & 100 & $<5$ & 0.4 & $<5$ & 1 & 180 & 2 & 16 & $<5$ & $<5$ & $<0.1$ & $<1$ & 140 & $<0.1$ & $<0.05$ & $<0.01$ & 8 & $<5$ \\
\hline 08/03/98 & 66 & $<5$ & 0.5 & $<5$ & 1 & 150 & 1 & 17 & $<5$ & $<5$ & $<0.1$ & $<1$ & 150 & $<0.1$ & 0.14 & 0.01 & 8 & $<5$ \\
\hline 08/10/98 & $<45$ & $<5$ & 0.4 & $<5$ & $<1$ & 110 & 1 & 17 & $<5$ & $<5$ & $<0.1$ & $<1$ & 180 & $<0.1$ & 0.13 & $<0.01$ & 3 & 6 \\
\hline
\end{tabular}

${ }^{1}$ Estimated from total recoverable concentration. 
Table 9. Water-quality data for samples collected from the Georgetown Lake outflow, site SW24L, 1997-98

$\left[{ }^{\circ} \mathrm{C}\right.$, degrees Celsius; $\mu \mathrm{S} / \mathrm{cm}$, microsiemens per centimeter at 25 degrees Celsius; $\mathrm{mg} / \mathrm{L}$, milligrams per liter; $\mu \mathrm{g} / \mathrm{L}$, micrograms per liter; <, less than; --, no data; see figure 2 for location of site SW24L]

\begin{tabular}{|c|c|c|c|c|c|c|c|c|c|c|c|c|c|}
\hline \multirow{2}{*}{$\begin{array}{l}\text { Sampling } \\
\text { date }\end{array}$} & \multirow{2}{*}{$\begin{array}{c}\text { Water } \\
\text { temperature } \\
\left({ }^{\circ} \mathbf{C}\right)\end{array}$} & \multirow{2}{*}{$\begin{array}{c}\text { Specific } \\
\text { conductance } \\
(\mu \mathrm{S} / \mathrm{cm})\end{array}$} & \multirow{2}{*}{$\mathrm{pH}$} & \multirow{2}{*}{$\begin{array}{l}\text { Dissolved } \\
\text { oxygen } \\
\text { (mg/L) }\end{array}$} & \multirow{2}{*}{$\begin{array}{c}\text { Alkalinity } \\
(\mathrm{mg} / \mathrm{L} \text { as } \\
\left.\mathrm{CaCO}_{3}\right)\end{array}$} & \multicolumn{4}{|c|}{$\begin{array}{l}\text { Dissolved cations } \\
\text { (mg/L) }\end{array}$} & \multicolumn{3}{|c|}{$\begin{array}{l}\text { Dissolved anions } \\
\text { (mg/L) }\end{array}$} & \multirow{2}{*}{$\begin{array}{c}\text { Dissolved } \\
\text { silica } \\
(\mathrm{mg} / \mathrm{L} \text { as } \\
\left.\mathrm{SiO}_{2}\right)\end{array}$} \\
\hline & & & & & & $\mathrm{Ca}$ & Mg & K & $\mathrm{Na}$ & $\mathrm{Cl}$ & $\mathbf{F}$ & $\mathrm{SO}_{4}$ & \\
\hline $08 / 14 / 97$ & 10.1 & 87 & 8.0 & 8.2 & 32 & 11 & 3.0 & $<2$ & 2.0 & 1.3 & $<0.20$ & 6.6 & 6.0 \\
\hline 08/20/97 & 11.0 & 90 & 9.0 & 8.2 & 33 & 11 & 3.2 & $<2$ & 2.2 & 1.4 & $<0.20$ & 6.6 & 6.2 \\
\hline 08/27/97 & 12.1 & 93 & 8.5 & 8.1 & 34 & 12 & 3.4 & $<2$ & 2.3 & 1.5 & $<0.20$ & 6.8 & 6.4 \\
\hline 09/05/97 & 13.5 & 97 & 8.3 & 10.5 & 35 & 13 & 3.7 & $<2$ & 2.6 & 2.3 & 0.31 & 8.52 & 6.3 \\
\hline 09/12/97 & 11.1 & 104 & 8.8 & 8.1 & 37 & 14 & 4.1 & $<2$ & 2.7 & 2.3 & 0.31 & 9.01 & 5.8 \\
\hline 09/19/97 & 10.5 & 105 & 8.9 & 8.7 & 39 & 14 & 4.1 & $<2$ & 2.8 & 1.9 & 0.22 & 8.3 & 6.0 \\
\hline $09 / 24 / 97$ & 9.0 & 108 & 8.6 & 9.2 & 40 & 13 & 4.1 & $<2$ & 2.7 & 1.9 & 0.21 & 8.3 & 5.8 \\
\hline 09/30/97 & 9.5 & 112 & 9.1 & 9.9 & 40 & 13 & 4.3 & $<2$ & 2.8 & 2.0 & 0.21 & 8.7 & 6.5 \\
\hline $10 / 10 / 97$ & 6.6 & 115 & 8.7 & 9.2 & 44 & 14 & 4.4 & $<2$ & 2.9 & 2.2 & 0.26 & 9.7 & 7.2 \\
\hline $10 / 23 / 97$ & 4.4 & 128 & 8.7 & 9.9 & 44 & 15 & 4.7 & $<2$ & 3.2 & 2.8 & 0.26 & 10.8 & 7.4 \\
\hline $11 / 06 / 97$ & 4.5 & 129 & 8.4 & 10.4 & 44 & 16 & 4.9 & $<2$ & 3.6 & 3.4 & 0.26 & 11.5 & 7.1 \\
\hline $12 / 04 / 97$ & 3.2 & 141 & 8.1 & 10.6 & 48 & 17 & 5.1 & $<2$ & 4.1 & 4.1 & 0.29 & 13.1 & 7.5 \\
\hline 01/08/98 & 0.1 & 144 & 8.1 & 10.2 & 51 & 18 & 5.6 & $<2$ & 4.2 & 4.4 & 0.30 & 14.3 & 7.5 \\
\hline 02/06/98 & 2.9 & 157 & 8.4 & 10.0 & 51 & 19 & 5.8 & $<2$ & 4.6 & 4.5 & 0.30 & 14.5 & 8.1 \\
\hline 03/04/98 & 4.0 & 169 & 7.9 & 10.4 & 53 & 18 & 6.2 & $<2$ & 4.9 & 7.4 & 0.31 & 14.9 & 6.9 \\
\hline 04/01/98 & 5.0 & 214 & 8.7 & 10.5 & 48 & 20 & 6.7 & 1.1 & 11 & 30 & 0.34 & 15.0 & -- \\
\hline 04/13/98 & 5.0 & 220 & 9.1 & 10.4 & 49 & 19 & 6.7 & 1.5 & 12 & 28 & 0.38 & 17.2 & -- \\
\hline $04 / 27 / 98$ & 4.5 & 201 & 9.4 & 10.7 & 42 & 20 & 6.7 & 1.3 & 10 & 30 & 0.29 & 16 & -- \\
\hline 05/04/98 & 9.0 & 230 & 9.3 & 9.4 & 46 & 21 & 7.1 & 0.9 & 14 & 39 & 0.30 & 18 & -- \\
\hline $05 / 11 / 98$ & 9.0 & 195 & 9.1 & 8.8 & 46 & 18 & 5.8 & 1.0 & 9.6 & 24 & 0.29 & 14 & -- \\
\hline 05/18/98 & 9.4 & 139 & 9.0 & -- & 42 & 15 & 4.6 & 0.7 & 6.8 & 13 & 0.25 & 11 & -- \\
\hline $05 / 26 / 98$ & 8.0 & 104 & 8.4 & 11.2 & 34 & 12 & 3.5 & 0.7 & 4.1 & 7.2 & 0.22 & 9 & -- \\
\hline 06/01/98 & 7.6 & 78 & 8.2 & 8.8 & 32 & 9.0 & 2.6 & 0.6 & 2.7 & 4.4 & 0.18 & 7 & -- \\
\hline 06/08/98 & 8.0 & 87 & 8.0 & 10.0 & 28 & 9.8 & 2.9 & 0.7 & 3.1 & 4.9 & 0.20 & 8 & -- \\
\hline $06 / 17 / 98$ & 8.5 & 86 & 9.0 & 9.0 & 30 & 9.5 & 2.7 & 1.0 & 2.5 & 4.0 & 0.21 & 7 & -- \\
\hline $06 / 22 / 98$ & 9.0 & 75 & 8.3 & 8.5 & 28 & 9.2 & 2.6 & 1.0 & 2.4 & 3.4 & 0.13 & 6 & -- \\
\hline 06/29/98 & 10.0 & 62 & 7.6 & 8.3 & 24 & 7.5 & 2.2 & 0.6 & 1.8 & 2.2 & 0.20 & 5 & -- \\
\hline 07/06/98 & 10.0 & 68 & 7.8 & 8.3 & 26 & 8.2 & 2.2 & 0.8 & 1.7 & 2.1 & 0.16 & 5 & -- \\
\hline $07 / 13 / 98$ & 11.3 & 68 & 8.3 & 8.6 & 24 & 8.8 & 2.5 & 0.8 & 2.0 & 2.3 & 0.16 & 6 & -- \\
\hline 07/20/98 & 12.5 & 77 & 8.1 & 8.2 & 28 & 9.8 & 2.7 & 0.8 & 2.0 & 2.2 & 0.18 & 7 & -- \\
\hline $07 / 27 / 98$ & 12.0 & 86 & 7.9 & 7.8 & 28 & 11 & 3.1 & 0.5 & 2.8 & 3.2 & 0.20 & 7 & -- \\
\hline 08/03/98 & 11.1 & 86 & 7.7 & 8.1 & 30 & 11 & 3.1 & $<0.5$ & 2.5 & 2.7 & 0.21 & 8 & -- \\
\hline 08/10/98 & -- & 91 & 8.2 & -- & 30 & 12 & 3.3 & 0.8 & 2.6 & 2.9 & 0.22 & 8 & -- \\
\hline
\end{tabular}


Table 9. Water-quality data for samples collected from the Georgetown Lake outflow, site SW24L, 1997-98—Continued

$\left[{ }^{\circ} \mathrm{C}\right.$, degrees Celsius; $\mu \mathrm{S} / \mathrm{cm}$, microsiemens per centimeter at 25 degrees Celsius; $\mathrm{mg} / \mathrm{L}$, milligrams per liter; $\mu \mathrm{g} / \mathrm{L}$, micrograms per liter; $<$, less than; --, no data; see figure 2 for location of site SW24L]

\begin{tabular}{|c|c|c|c|c|c|c|c|c|c|c|c|c|c|c|c|}
\hline \multirow{2}{*}{$\begin{array}{l}\text { Sampling } \\
\text { date }\end{array}$} & \multicolumn{13}{|c|}{$\begin{array}{c}\begin{array}{c}\text { Dissolved metals } \\
(\mu \mathrm{g} / \mathrm{L})\end{array} \\
\end{array}$} & \multirow{2}{*}{$\begin{array}{c}\text { Hardness } \\
(\mathrm{mg} / \mathrm{L} \text { as } \\
\left.\mathrm{CaCO}_{3}\right)\end{array}$} & \multirow{2}{*}{$\begin{array}{c}\text { Dissolvec } \\
\text { organic } \\
\text { carbon } \\
\text { (mg/L } \\
\text { as C) }\end{array}$} \\
\hline & Al & As & Cd & $\mathrm{Cr}$ & $\mathrm{Cu}$ & $\mathrm{Fe}$ & $\mathrm{Pb}$ & Mn & $\mathrm{Ni}$ & Se & $\mathbf{A g}$ & $\mathrm{TI}$ & $Z n$ & & \\
\hline $08 / 14 / 97$ & $<40$ & $<1$ & $<0.5$ & $<0.8$ & 1.0 & 59 & $<0.8$ & 21 & $<11$ & $<1$ & $<0.2$ & $<1$ & 141 & 39.7 & $<1.5$ \\
\hline 08/20/97 & $<40$ & $<1$ & 0.6 & $<0.8$ & 0.9 & 68 & 1.0 & 26 & $<11$ & $<1$ & $<0.2$ & $<1$ & 137 & 41.3 & $<1.5$ \\
\hline $08 / 27 / 97$ & $<40$ & $<1$ & 0.5 & $<0.8$ & 1.0 & 64 & 0.9 & 29 & $<11$ & $<1$ & $<0.2$ & $<1$ & 160 & 43.6 & $<1.5$ \\
\hline 09/05/97 & $<40$ & $<50$ & $<0.5$ & $<4$ & 0.8 & 70 & 2.1 & 37 & $<11$ & $<40$ & $<6$ & $<50$ & 184 & 46.8 & $<1.5$ \\
\hline $09 / 12 / 97$ & $<40$ & $<50$ & $<0.5$ & $<4$ & 0.8 & 100 & 1.3 & 32 & $<11$ & $<40$ & $<6$ & $<50$ & 176 & 50.8 & $<1.5$ \\
\hline 09/19/97 & $<40$ & $<50$ & $<0.5$ & $<4$ & $<0.8$ & 104 & 1.2 & 30 & $<11$ & $<40$ & $<6$ & $<50$ & 180 & 51.3 & $<1.5$ \\
\hline $09 / 24 / 97$ & $<40$ & $<50$ & $<0.5$ & $<4$ & 0.8 & 106 & 1.1 & 32 & $<11$ & $<40$ & $<6$ & $<50$ & 191 & 49.4 & $<1.5$ \\
\hline 09/30/97 & $<40$ & $<50$ & $<0.5$ & $<4$ & 0.8 & 109 & 1.1 & 27 & $<11$ & $<40$ & $<6$ & $<50$ & 174 & 51.2 & $<1.5$ \\
\hline $10 / 10 / 97$ & $<40$ & $<50$ & $<0.5$ & $<4$ & $<0.8$ & 129 & 2.1 & 38 & $<11$ & $<40$ & $<6$ & $<50$ & 200 & 53.9 & $<1.5$ \\
\hline $10 / 23 / 97$ & $<40$ & $<50$ & $<0.5$ & $<4$ & 0.8 & 86 & 2.4 & 35 & $<11$ & $<40$ & $<6$ & $<50$ & 268 & 57.2 & $<1.5$ \\
\hline $11 / 06 / 97$ & $<40$ & $<50$ & $<0.5$ & $<4$ & $<0.8$ & 120 & 1.1 & 30 & $<11$ & $<40$ & $<6$ & $<50$ & 354 & 60.0 & $<1.5$ \\
\hline $12 / 04 / 97$ & $<40$ & $<50$ & 1.0 & $<4$ & $<0.8$ & 64 & $<0.8$ & 27 & $<11$ & $<40$ & $<6$ & $<50$ & 430 & 62.1 & $<1.5$ \\
\hline 01/08/98 & $<40$ & $<50$ & 0.8 & $<4$ & $<0.8$ & 75 & $<0.8$ & 34 & $<11$ & $<40$ & $<6$ & $<50$ & 508 & 68.2 & $<1.5$ \\
\hline 02/06/98 & $<40$ & $<50$ & 0.9 & 4 & $<0.8$ & 102 & $<0.8$ & 30 & $<11$ & $<40$ & $<6$ & $<50$ & 413 & 70.8 & $<1.5$ \\
\hline 03/04/98 & $<40$ & $<50$ & 0.7 & $<4$ & $<0.8$ & 135 & 1.0 & 28 & $<11$ & $<40$ & $<6$ & $<50$ & 346 & 71.3 & $<1.5$ \\
\hline 04/01/98 & $<45$ & $<5$ & 0.8 & $<5$ & $<1$ & 60 & $<1$ & 33 & $<1$ & $<5$ & $<0.1$ & $<1$ & 240 & 77.5 & 1 \\
\hline 04/13/98 & $<45$ & $<5$ & 0.6 & $<5$ & 0.6 & 74 & $<1$ & 31 & $<10$ & $<2$ & $<0.2$ & $<1$ & 242 & 76.2 & 6 \\
\hline $04 / 27 / 98$ & $<45$ & $<5$ & 0.8 & $<5$ & $<1$ & 60 & $<1$ & 27 & $<1$ & $<5$ & $<0.1$ & $<1$ & 240 & 77.5 & 3 \\
\hline $05 / 04 / 98$ & $<45$ & $<5$ & 1.6 & $<5$ & $<1$ & 70 & $<1$ & 31 & $<1$ & $<5$ & $<0.1$ & $<1$ & 270 & 81.7 & 2 \\
\hline $05 / 11 / 98$ & $<45$ & $<5$ & 0.9 & $<5$ & 1 & 60 & $<1$ & 25 & $<1$ & $<5$ & $<0.1$ & $<1$ & 290 & 68.8 & 3 \\
\hline $05 / 18 / 98$ & $<45$ & $<5$ & 0.7 & $<5$ & 1 & 60 & $<1$ & 18 & $<1$ & $<5$ & $<0.1$ & $<1$ & 240 & 56.4 & 3 \\
\hline $05 / 26 / 98$ & $<45$ & $<5$ & 0.7 & $<5$ & 2 & 50 & $<1$ & 21 & $<1$ & $<5$ & $<0.1$ & $<1$ & 220 & 44.4 & 6 \\
\hline 06/01/98 & 47 & $<5$ & 0.5 & $<5$ & 2 & 50 & 1 & 20 & $<1$ & $<5$ & $<0.1$ & $<1$ & 160 & 33.2 & 5 \\
\hline 06/08/98 & $<45$ & $<5$ & 0.5 & $<5$ & $<1$ & 40 & $<1$ & 15 & $<1$ & $<5$ & $<0.1$ & $<1$ & 150 & 36.4 & 3 \\
\hline $06 / 17 / 98$ & $<45$ & $<5$ & 0.4 & $<5$ & $<1$ & 40 & $<1$ & 14 & $<1$ & $<5$ & $<0.1$ & $<1$ & 120 & 34.8 & 4 \\
\hline $06 / 22 / 98$ & $<45$ & $<5$ & 0.5 & $<5$ & $<1$ & 40 & $<1$ & 10 & $<1$ & $<5$ & $<0.1$ & $<1$ & 120 & 33.7 & 3 \\
\hline 06/29/98 & $<45$ & $<5$ & 0.3 & $<5$ & $<1$ & 40 & $<1$ & 12 & $<1$ & $<5$ & $<0.1$ & $<1$ & 99 & 27.8 & 3 \\
\hline 07/06/98 & $<45$ & $<5$ & 0.4 & $<5$ & $<1$ & 30 & $<1$ & 13 & $<1$ & $<5$ & $<0.1$ & $<1$ & 110 & 29.5 & 3 \\
\hline 07/13/98 & $<45$ & $<5$ & 0.3 & $<5$ & $<1$ & 40 & $<1$ & 14 & $<1$ & $<5$ & $<0.1$ & $<1$ & 110 & 32.3 & 4 \\
\hline 07/20/98 & $<45$ & $<5$ & 0.3 & $<5$ & $<1$ & 50 & $<1$ & 17 & $<1$ & $<5$ & $<0.1$ & $<1$ & 130 & 35.6 & 6 \\
\hline 07/27/98 & $<45$ & $<5$ & 0.3 & $<5$ & $<1$ & 50 & $<1$ & 26 & $<5$ & $<5$ & $<0.1$ & $<1$ & 120 & 40.2 & 8 \\
\hline 08/03/98 & $<45$ & $<5$ & 0.4 & $<5$ & $<1$ & 60 & $<1$ & 19 & $<1$ & $<5$ & $<0.1$ & $<1$ & 140 & 40.2 & -- \\
\hline 08/10/98 & $<45$ & $<5$ & 0.4 & $<5$ & $<1$ & 60 & $<1$ & 23 & $<1$ & $<5$ & $<0.1$ & $<1$ & 170 & 43.6 & 3 \\
\hline
\end{tabular}


Table 9. Water-quality data for samples collected from the Georgetown Lake outflow, site SW24L, 1997-98-Continued

$\left[{ }^{\circ} \mathrm{C}\right.$, degrees Celsius; $\mu \mathrm{S} / \mathrm{cm}$, microsiemens per centimeter at 25 degrees Celsius; $\mathrm{mg} / \mathrm{L}$, milligrams per liter; $\mu \mathrm{g} / \mathrm{L}$, micrograms per liter; <, less than; ,-- no data; see figure 2 for location of site SW24L]

\begin{tabular}{|c|c|c|c|c|c|c|c|c|c|c|c|c|c|c|c|c|c|c|}
\hline \multirow[b]{2}{*}{$\begin{array}{l}\text { Sampling } \\
\text { date }\end{array}$} & \multicolumn{13}{|c|}{$\begin{array}{c}\text { Total recoverable metals } \\
(\mu \mathrm{g} / \mathrm{L})\end{array}$} & \multicolumn{3}{|c|}{$\begin{array}{l}\text { Total nutrients } \\
\text { (mg/L) }\end{array}$} & \multirow{2}{*}{$\begin{array}{c}\text { Total } \\
\text { organic } \\
\text { carbon } \\
\text { (mg/L } \\
\text { as C) }\end{array}$} & \multirow{2}{*}{$\begin{array}{c}\text { Total } \\
\text { sus- } \\
\text { pended } \\
\text { solids } \\
\text { (mg/L) }\end{array}$} \\
\hline & Al & As & Cd & $\mathrm{Cr}$ & $\mathrm{Cu}$ & $\mathrm{Fe}$ & $\mathrm{Pb}$ & Mn & $\mathrm{Ni}$ & Se & $\mathrm{Ag}$ & TI & $Z n$ & $\begin{array}{l}\text { Ammonia } \\
\text { (as N) }\end{array}$ & $\begin{array}{c}\text { Nitrite } \\
\text { plus } \\
\text { nitrate } \\
\text { (as N) }\end{array}$ & $\begin{array}{l}\text { Phos- } \\
\text { phorus } \\
\text { (as P) }\end{array}$ & & \\
\hline $08 / 14 / 97$ & $<40$ & $<1$ & 0.7 & $<0.8$ & 2.3 & 138 & 1.4 & 25 & $<11$ & $<1$ & $<0.2$ & $<1$ & 158 & $<0.05$ & 0.07 & $<0.02$ & $<1.5$ & $<4$ \\
\hline 08/20/97 & $<40$ & $<1$ & 0.6 & $<0.8$ & 1.6 & 150 & 1.6 & 29 & $<11$ & $<1$ & $<0.2$ & $<1$ & 167 & $<0.05$ & 0.05 & $<0.02$ & $<1.5$ & $<4$ \\
\hline $08 / 27 / 97$ & 125 & $<1$ & 0.8 & 1.9 & 1.8 & 223 & 3.6 & 36 & $<11$ & $<1$ & $<0.2$ & $<1$ & 199 & $<0.05$ & 0.10 & $<0.02$ & $<1.5$ & $<4$ \\
\hline 09/05/97 & 208 & $<50$ & $<0.5$ & $<4$ & 3.4 & 374 & 9.7 & 49 & $<11$ & $<40$ & $<6$ & $<50$ & 241 & $<0.05$ & 0.10 & $<0.02$ & 1.8 & $<6$ \\
\hline 09/12/97 & $<40$ & $<50$ & $<0.5$ & $<4$ & 1.5 & 204 & 2.2 & 37 & $<11$ & $<40$ & $<6$ & $<50$ & 231 & $<0.05$ & 0.08 & 0.10 & $<1.5$ & $<4$ \\
\hline 09/19/97 & $<40$ & $<50$ & $<0.5$ & $<4$ & 1.8 & 211 & 2.0 & 35 & $<11$ & $<40$ & $<6$ & $<50$ & 235 & $<0.05$ & 0.06 & 0.03 & $<1.5$ & $<4$ \\
\hline $09 / 24 / 97$ & $<40$ & $<50$ & $<0.5$ & $<4$ & 1.0 & 226 & 2.4 & 36 & $<11$ & $<40$ & $<6$ & $<50$ & 253 & $<0.05$ & $<0.05$ & 0.03 & $<1.5$ & $<4$ \\
\hline 09/30/97 & $<40$ & $<50$ & $<0.5$ & $<4$ & 3.6 & 212 & 2.1 & 32 & $<11$ & $<40$ & $<6$ & $<50$ & 247 & $<0.05$ & 0.05 & 0.03 & $<1.5$ & $<4$ \\
\hline $10 / 10 / 97$ & $<40$ & $<50$ & $<0.5$ & $<4$ & 0.9 & 256 & 4.5 & 43 & $<11$ & $<40$ & $<6$ & $<50$ & 273 & $<0.05$ & 0.06 & $<0.02$ & $<1.5$ & $<4$ \\
\hline $10 / 23 / 97$ & $<40$ & $<50$ & 0.6 & $<4$ & 0.9 & 167 & 4.5 & 38 & $<11$ & $<40$ & $<6$ & $<50$ & 306 & $<0.05$ & 0.09 & $<0.02$ & $<1.5$ & $<4$ \\
\hline $11 / 06 / 97$ & $<40$ & $<50$ & 0.5 & $<4$ & 1.8 & 222 & 2.4 & 32 & $<11$ & $<40$ & $<6$ & $<50$ & 367 & $<0.05$ & 0.14 & $<0.02$ & $<1.5$ & $<4$ \\
\hline $12 / 04 / 97$ & $<40$ & $<50$ & 1.6 & $<4$ & $<0.8$ & 130 & $<0.8$ & 30 & $<11$ & $<40$ & $<6$ & $<50$ & 452 & $<0.05$ & 0.17 & $<0.02$ & $<1.5$ & $<4$ \\
\hline 01/08/98 & $<40$ & $<50$ & 1.3 & 6 & $<0.8$ & 244 & 3.1 & 100 & 19 & $<40$ & $<6$ & $<50$ & 518 & $<0.05$ & 0.21 & $<0.02$ & $<1.5$ & $<4$ \\
\hline 02/06/98 & $<40$ & $<50$ & 1.3 & 8 & $<0.8$ & 266 & 1.1 & 34 & $<11$ & $<40$ & $<6$ & $<50$ & 446 & $<0.05$ & 0.15 & $<0.02$ & $<1.5$ & $<4$ \\
\hline 03/04/98 & $<40$ & $<50$ & 1.4 & $<4$ & $<0.8$ & 399 & 2.4 & 37 & $<11$ & $<40$ & $<6$ & $<50$ & 424 & $<0.05$ & 0.14 & $<0.02$ & $<1.6$ & $<4$ \\
\hline 04/01/98 & 67 & $<5$ & 1.2 & $<5$ & $<1$ & 260 & 3.0 & 46 & $<1$ & -- & $<0.1$ & $<1$ & 440 & $<0.2$ & 0.18 & 0.02 & 1 & $<5$ \\
\hline 04/13/98 & 78 & $<5$ & 1.2 & $<5$ & $<2$ & 290 & 2.5 & 39 & $<10$ & -- & $<0.2$ & $<1$ & 448 & $<0.05$ & 0.22 & $<0.02$ & 1 & $<4$ \\
\hline $04 / 27 / 98$ & 70 & $<5$ & 1.0 & $<5$ & $<1$ & 190 & 2 & 32 & $<1$ & -- & $<0.1$ & $<1$ & 440 & $<0.2$ & 0.14 & 0.01 & 2 & 6 \\
\hline 05/04/98 & 60 & $<5$ & 1.6 & $<5$ & 1 & 230 & 3 & 42 & $<1$ & -- & $<0.1$ & $<1$ & 540 & $<0.2$ & 0.14 & $<0.01$ & 2 & $<5$ \\
\hline 05/11/98 & 70 & $<5$ & 1.2 & $<5$ & 2 & 210 & 3 & 33 & $<1$ & -- & $<0.1$ & $<1$ & 470 & $<0.2$ & $<0.05$ & 0.02 & 3 & 8 \\
\hline 05/18/98 & 80 & $<5$ & 1.0 & $<5$ & 2 & 200 & 2 & 27 & $<1$ & -- & $<0.1$ & $<1$ & 340 & $<0.2$ & $<0.05$ & 0.02 & 4 & $<5$ \\
\hline 05/26/98 & 90 & $<5$ & 0.7 & $<5$ & 3 & 150 & 3 & 25 & $<1$ & -- & $<0.1$ & $<1$ & 240 & $<0.2$ & $<0.05$ & $<0.01$ & 12 & $<5$ \\
\hline 06/01/98 & 130 & $<5$ & 0.6 & $<5$ & 3 & 230 & 5 & 27 & $<1$ & -- & 0.2 & $<1$ & 180 & $<0.2$ & $<0.05$ & 0.02 & 3 & $<5$ \\
\hline 06/08/98 & 60 & $<5$ & 0.6 & $<5$ & 2 & 100 & 2 & 21 & $<1$ & -- & $<0.1$ & $<1$ & 160 & $<0.2$ & $<0.05$ & 0.02 & 3 & $<5$ \\
\hline 06/17/98 & 58 & $<5$ & 0.4 & $<5$ & $<1$ & 100 & $<1$ & 15 & $<5$ & -- & $<0.1$ & $<1$ & 140 & $<0.2$ & 0.05 & 0.02 & 3 & $<5$ \\
\hline $06 / 22 / 98$ & 70 & $<5$ & 0.5 & $<5$ & $<1$ & 110 & $<1$ & 13 & $<5$ & $<5$ & $<0.1$ & $<1$ & 130 & $<0.2$ & 0.07 & 0.02 & 3 & $<5$ \\
\hline $06 / 29 / 98$ & 68 & $<5$ & 0.3 & $<5$ & 1 & 150 & $<1$ & 15 & $<5$ & $<5$ & $<0.1$ & $<1$ & 100 & $<0.2$ & 0.08 & 0.02 & 3 & $<5$ \\
\hline 07/06/98 & $<45$ & $<5$ & 0.3 & $<5$ & $<1$ & 90 & $<1$ & 15 & $<5$ & $<5$ & $<0.1$ & $<1$ & 110 & $<0.2$ & 0.08 & $<0.01$ & 2 & $<5$ \\
\hline 07/13/98 & $<45$ & $<5$ & 0.4 & $<5$ & 1 & 120 & 1 & 15 & $<5$ & $<5$ & $<0.1$ & $<1$ & 120 & $<0.2$ & 0.08 & 0.02 & 5 & $<5$ \\
\hline 07/20/98 & $<45$ & $<5$ & 0.4 & $<5$ & 1 & 100 & 1 & 20 & $<5$ & $<5$ & $<0.1$ & $<1$ & 130 & $<0.2$ & 0.07 & 0.02 & 5 & $<5$ \\
\hline $07 / 27 / 98$ & 190 & $<5$ & 0.5 & $<5$ & 2 & 360 & 6 & 39 & $<1$ & $<5$ & $<0.1$ & $<1$ & 160 & $<0.1$ & 0.11 & 0.02 & 6 & $<5$ \\
\hline 08/03/98 & 58 & $<5$ & 0.4 & $<5$ & 1 & 150 & 2 & 22 & $<5$ & $<5$ & $<0.1$ & $<1$ & 140 & $<0.1$ & 0.12 & 0.01 & 7 & $<5$ \\
\hline 08/10/98 & 140 & $<5$ & 0.4 & $<5$ & 2 & 340 & 7 & 34 & $<5$ & $<5$ & $<0.1$ & $<1$ & 180 & $<0.1$ & 0.12 & 0.02 & 3 & 8 \\
\hline
\end{tabular}



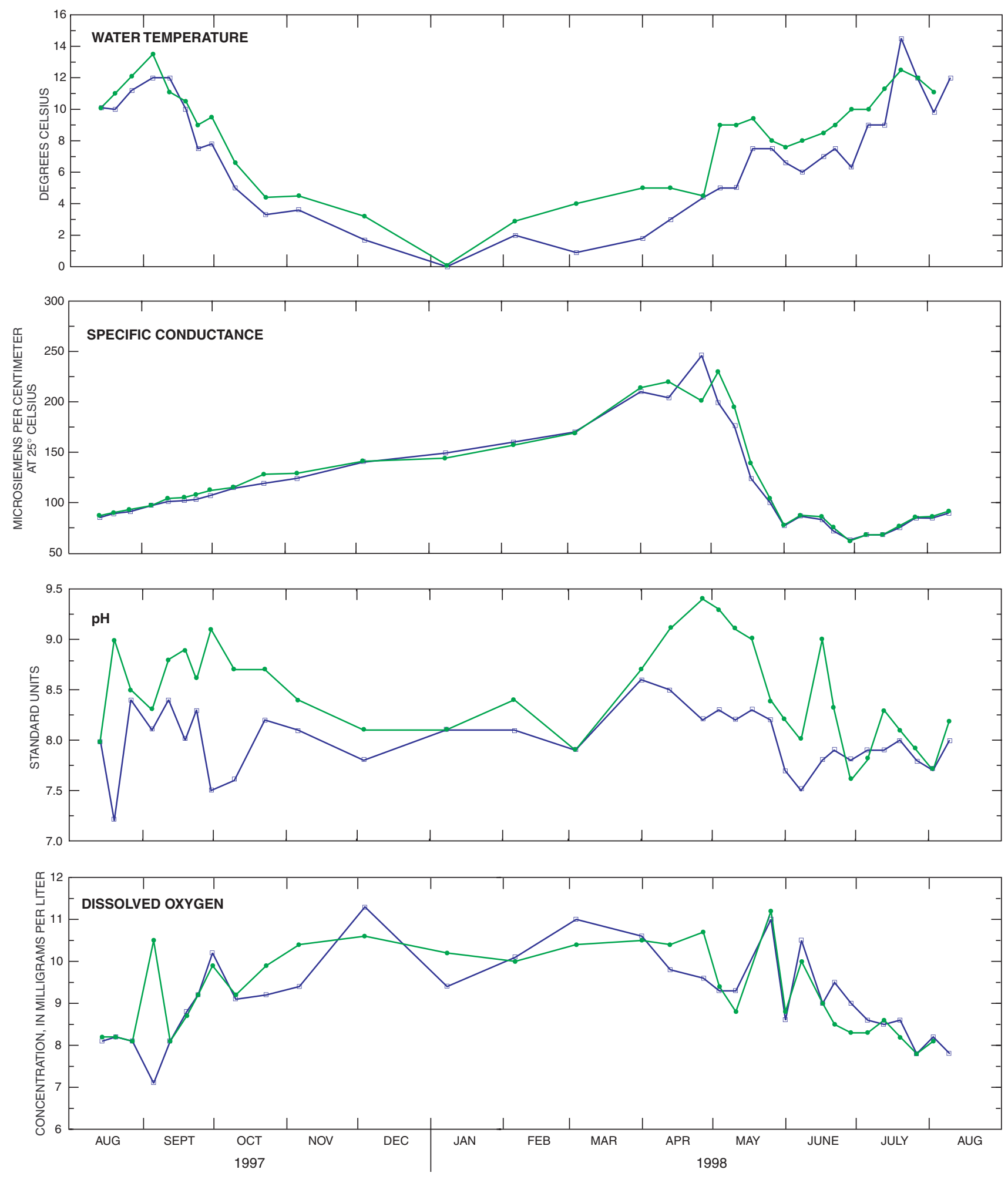

EXPLANATION

$\simeq$ Inflow samples (SW24U)

$\rightarrow$ Outflow samples (SW24L)

Note: See figure 2 for site locations

Figure 12. Field measurements in Georgetown Lake inflow and outflow samples, 1997-98. 
sufficient concentrations and numbers of samples to allow some conclusions regarding their behavior in Georgetown Lake.

Dissolved cadmium and dissolved lead in Clear Creek inflow and outflow water exceeded the acute and chronic standards during part of the sampling period, whereas dissolved zinc exceeded both standards in inflow and outflow water during the entire sampling period. Dissolved aluminum, dissolved copper, dissolved iron, and dissolved manganese did not exceed the standards during the sampling period.

Only one inflow and one outflow sample (both on June 1, 1998) had dissolved aluminum concentrations that equaled or exceeded reporting limits (fig. 13). Most aluminum flowing into and out of the reservoir is particulate, as indicated by the fact that total recoverable aluminum often exceeded the reporting limit. The exceedances were most numerous during the period of rising and peak flow (fig. 3) from spring snowmelt. However, the inflow sample collected on December 4, 1997, had the largest concentration of total recoverable aluminum, which apparently resulted from the inflow of abundant sediment that was observed on that day. Generally larger concentrations of total recoverable aluminum in inflow than in outflow samples indicate that the reservoir is a sink for sedimentary aluminum during periods of increased discharge and sediment loads. By contrast, during late summer, outflow concentrations of total recoverable aluminum at times exceeded inflow concentrations, probably because of agitation of bottom sediments by strong winds.

Dissolved cadmium concentrations (fig. 14) exceeded the chronic standard in inflow water from late October through mid-June and sporadically at other times. The outflow water occasionally exceeded the chronic standard. Concentrations and seasonal distributions generally were similar for dissolved and total recoverable cadmium, indicating that the cadmium was mostly in dissolved form. The most prevalent form of dissolved cadmium in freshwater is the $\mathrm{Cd}^{2+}$ ion (Moore, 1991). Except for the anomalous concentrations of December 4, 1997 (which were affected by input of abundant sediment), the distribution of inflow and outflow concentrations of dissolved and total recoverable cadmium generally were similar to the distribution of specific-conductance measurements (fig. 12), consistent with the largely dissolved form of the element. Inflow concentrations of dissolved and total recoverable cadmium generally exceeded outflow concentrations, indicating that the reservoir was a sink for cadmium, probably by sorption onto bottom sediment. This hypothesis is consistent with the generally smaller concentrations of dissolved (table 6) and total recoverable (mostly dissolved) (fig. 11; table 6) cadmium in reservoir-profile samples collected from nearest the bottom of the reservoir during March 11-12, 1998. However, during February-April 1998, the substantial increase in dissolved iron concentrations in outflow samples relative to inflow samples corresponds to the period when the reservoir sediments contributed substantial quantities of colloidal iron to the water column (discussed later in this section). This correspondence suggests the possibility that dissolved cadmium was converted to total recoverable cadmium by sorption onto colloidal iron during this period.

Concentrations of copper (fig. 15) in inflow and outflow water were low in both dissolved (less than $0.8-2.0 \mu \mathrm{g} / \mathrm{L}$ ) and total recoverable (less than 0.8-3.6 $\mu \mathrm{g} / \mathrm{L}$ ) samples. Peak concentrations of dissolved copper occurred on the rising limb of discharge during spring snowmelt. Early on the rising limb (May 4 and 11, 1998), dissolved copper concentrations were greater in inflow samples than in outflow samples, probably in response to initial flushing from the upstream drainage and to dilution, sorption, and biological uptake in the reservoir. As discharge increased and peaked (May 18 through June 1, 1998), dissolved copper concentrations in the inflow and outflow samples were equal while the short average residence time minimized sorption and biological uptake in the reservoir. During fall 1997 and June and July 1998, dissolved copper concentrations generally were larger in outflow samples than in inflow samples. Dissolved copper was not reported in either sample set during the period of ice cover. The relation between concentrations of total recoverable copper in inflow and outflow samples was similar to the relation for dissolved copper: (1) Greater inflow concentrations during early snowmelt; (2) equal concentrations during peak flow; (3) substantially greater outflow concentrations during summer and fall; and (4) none reported for the period of ice cover (except for the turbid inflow sample collected on December 4, 1997). Overall, copper data show that Georgetown Lake 

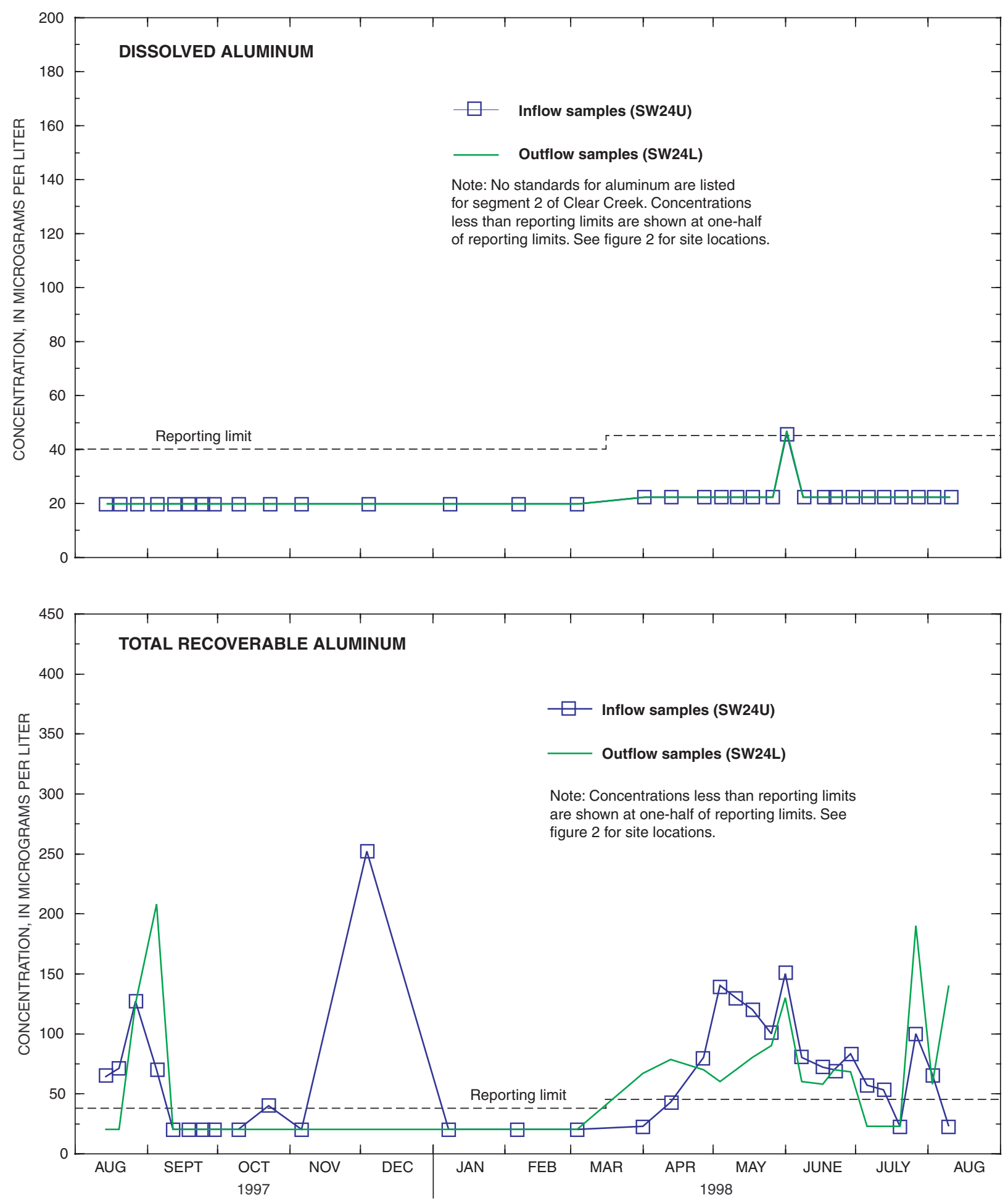

Figure 13. Dissolved and total recoverable aluminum concentrations in Georgetown Lake inflow and outflow samples, 1997-98. 

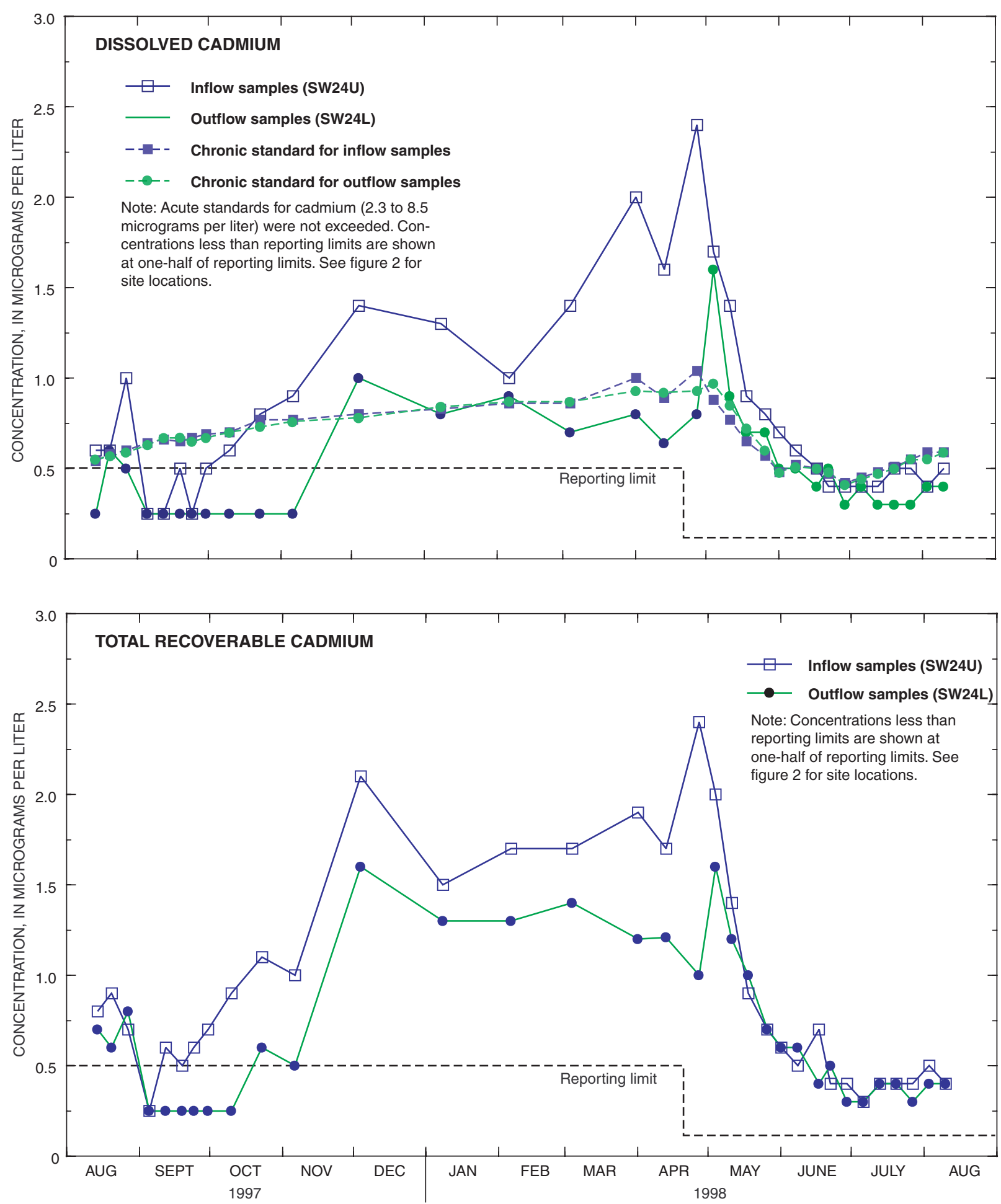

Figure 14. Dissolved and total recoverable cadmium concentrations in Georgetown Lake inflow and outflow samples, 1997-98. 

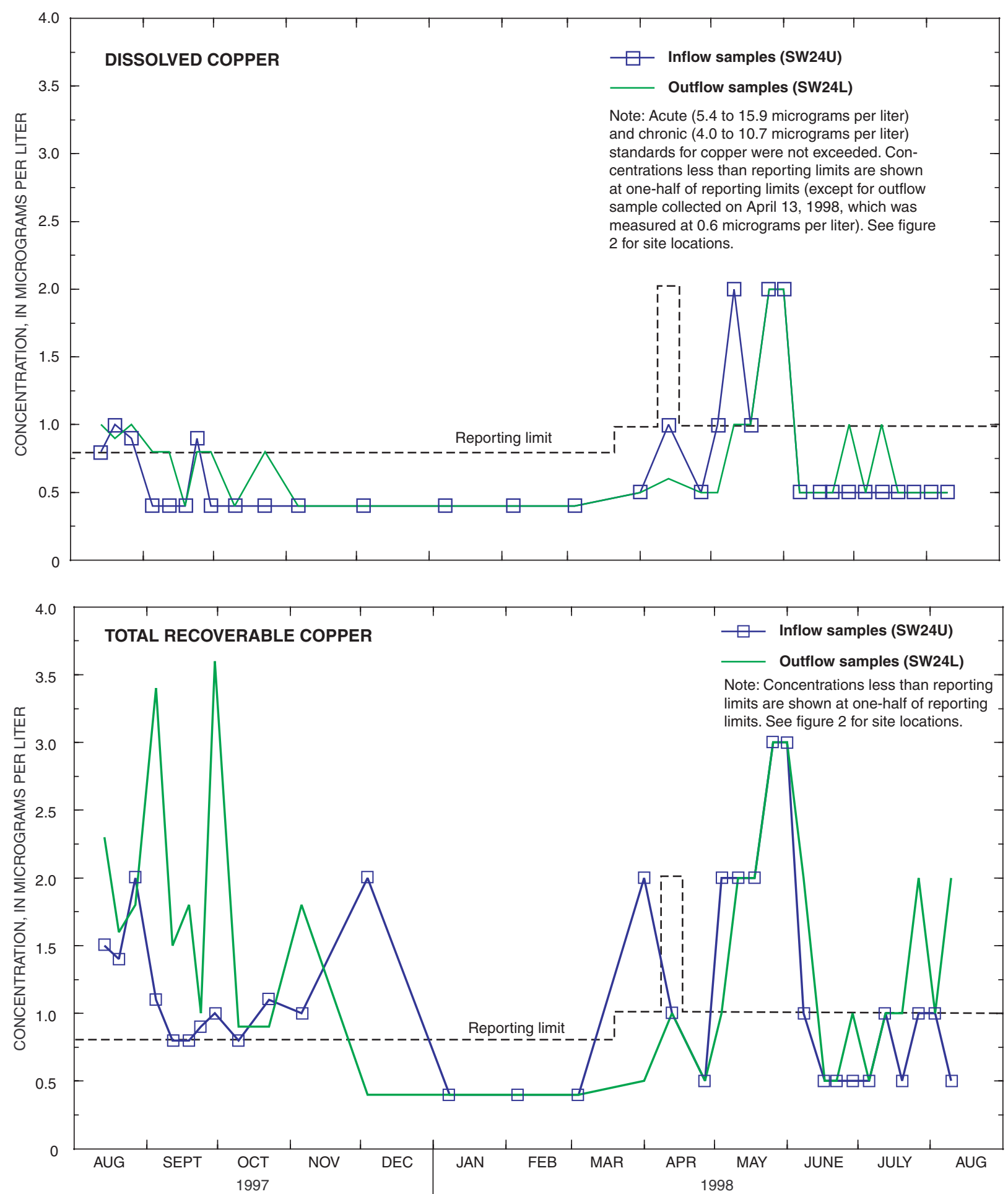

Figure 15. Dissolved and total recoverable copper concentrations in Georgetown Lake inflow and outflow samples, 1997-98. 
collected dissolved and particulate copper during early snowmelt, transported dissolved and particulate copper during peak flow, and contributed dissolved and particulate copper to Clear Creek during summer and fall. Contributions in summer and fall probably resulted mostly from agitation and resuspension of bottom sediments by wind action in shallower areas.

Except for the inflow sample collected on August 14, 1997, dissolved iron concentrations (fig. 16) in inflow and outflow samples substantially exceeded concentrations expected for their environments. According to Hem (1985), oxygenated water with the range of $\mathrm{pH}$ measured for these samples would dissolve less than $10 \mu \mathrm{g} / \mathrm{L}$ of iron; furthermore, Hem attributes larger reported concentrations under these conditions to particulates that pass through a $0.45-\mu \mathrm{m}$ filter. Concentrations of dissolved iron for outflow samples substantially exceeded concentrations for inflow samples, except during the period of high discharge when concentrations of dissolved iron were smallest and outflow concentrations were only slightly greater than inflow concentrations. These facts indicate that reservoir sediment contributed substantial quantities of apparently dissolved iron to outflow water, probably as colloidal ferric hydroxide $\left[\mathrm{Fe}(\mathrm{OH})_{3}\right]$ or possibly as organic complexes. When pyrite in bottom sediments is exposed to oxygen-rich water or ferric hydroxide in bottom sediments is exposed to reducing substances (such as organic matter), iron will tend to go into solution as ferrous iron (Hem, 1985). These processes are consistent with the larger concentrations of total recoverable iron in profile samples collected nearest the reservoir bottom during March 11-12, 1998 (fig. 11). However, outflow water during September 10-11, 1998, contained little ferrous iron (table 10), indicating that any solubilized iron was oxidized by the time it reached the outflow sampling site. This oxidation state is consistent with the high dissolved-oxygen concentrations measured in reservoir profiles during summer and winter (fig. 12). Furthermore, sediment-interface water samples collected on March 23, 1998, indicated that most of the iron supplied by the sediment consisted of ferric colloidal or microcrystalline iron. The relatively small concentrations of dissolved organic carbon and total organic carbon in inflow (table 8) and outflow (table 9) samples support the hypothesis that most of the apparently dissolved iron in outflow water consisted of colloids of ferric hydroxide. Relatively slow water currents would be sufficient to transport these small colloids from the bottom of the reservoir.

Concentrations of total recoverable iron were about twice the concentrations of dissolved iron for most inflow and outflow samples during the sampling period. During rising and peak flows associated with snowmelt, concentrations of total recoverable iron in inflow samples exceeded concentrations in outflow samples, indicating that the reservoir was resupplied with iron during this period. Excluding the inflow sample on December 4, 1997, concentrations of total recoverable iron in outflow samples generally exceeded concentrations in inflow samples during the remainder of the year, indicating that reservoir sediment was a source of particulate iron. Concentrations of total recoverable iron in outflow samples generally were not smaller during winter months, when discharge was relatively small and when the reservoir was covered with ice and wind could not disturb sediments. This relation indicates that most of the particulate iron probably represented larger colloids and microcrystals of ferric hydroxide that were removed from the samples collected for dissolved metals by filtration.

On September 10-11, 1998, the reservoir contributed an average of about $130 \mu \mathrm{g} / \mathrm{L}$ of ferric iron to Clear Creek over a 16-hour period beginning in early afternoon (table 10). The concentration of total ferric iron in outflow water (table 10) was essentially constant over this period, although outflow $\mathrm{pH}$ varied by 0.28 unit. The average residence time of about 3.5 days (figs. 3 and 4 ) during this period probably allowed substantial mixing of water affected by light and darkness, obscuring possible diurnal effects on iron concentrations caused by fluctuations in $\mathrm{pH}$ and dissolved-oxygen concentrations in response to photosynthesis.

Dissolved lead concentrations (fig. 17) exceeded the chronic standard slightly on several occasions during the study. The generally larger concentrations of dissolved lead in outflow samples than in inflow samples during late summer and early fall indicates that reservoir sediment was a source of dissolved lead. Generally larger concentrations of total recoverable lead than dissolved lead in inflow and outflow samples indicate that a substantial fraction of lead was 

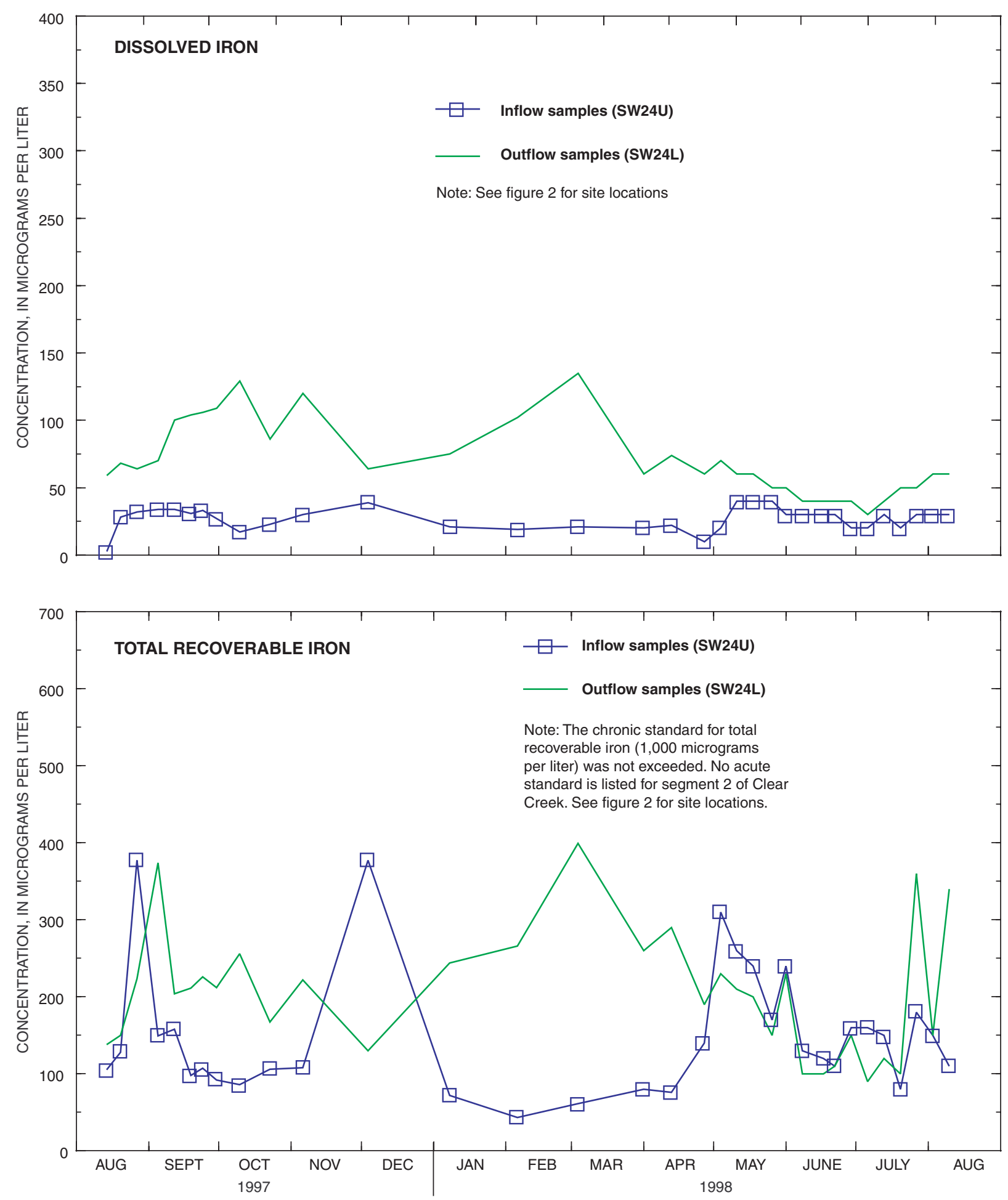

Figure 16. Dissolved and total recoverable iron concentrations in Georgetown Lake inflow and outflow samples, 1997-98. 
Table 10. Field measurements and iron concentrations in Georgetown Lake inflow and outflow samples during a 16-hour period, September 10-11, 1998

$\left[\mathrm{mg} / \mathrm{L}\right.$, milligrams per liter; $\mu \mathrm{S} / \mathrm{cm}$, microsiemens per centimeter at 25 degrees Celsius; ${ }^{\circ} \mathrm{C}$, degrees Celsius; $\mu \mathrm{g} / \mathrm{L}$, micrograms per liter; <, less than; see figure 2 for sampling-site locations]

\begin{tabular}{|c|c|c|c|c|c|c|c|}
\hline $\begin{array}{l}\text { Sampling } \\
\text { date }\end{array}$ & $\begin{array}{l}\text { Sampling } \\
\text { time }\end{array}$ & $\begin{array}{c}\text { Dissolved } \\
\text { oxygen } \\
\text { (mg/L) }\end{array}$ & $\mathrm{pH}$ & $\begin{array}{c}\text { Specific } \\
\text { conductance } \\
(\mu \mathrm{S} / \mathrm{cm})\end{array}$ & $\begin{array}{c}\text { Water } \\
\text { temperature } \\
\left({ }^{\circ} \mathrm{C}\right)\end{array}$ & $\begin{array}{l}\text { Total } \\
\text { ferrous iron } \\
(\mu \mathrm{g} / \mathrm{L})\end{array}$ & $\begin{array}{c}\text { Total ferrous } \\
\text { plus } \\
\text { ferric iron } \\
(\mu \mathrm{g} / \mathrm{L})\end{array}$ \\
\hline \multicolumn{8}{|c|}{ Site SW24U, Georgetown Lake inflow } \\
\hline 09/10/98 & 1410 & 7.57 & 7.96 & 121 & 12.3 & 10 & 70 \\
\hline 09/10/98 & 1526 & 7.56 & 8.15 & 123 & 12.8 & $<10$ & 70 \\
\hline 09/10/98 & 1636 & 7.62 & 8.05 & 124 & 12.2 & 10 & 70 \\
\hline 09/10/98 & 1744 & 7.70 & 8.08 & 123 & 12.0 & $<10$ & 80 \\
\hline 09/10/98 & 1908 & 7.83 & 8.04 & 128 & 11.4 & 10 & 80 \\
\hline 09/10/98 & 2036 & 7.95 & 8.02 & 123 & 11.2 & $<10$ & 80 \\
\hline 09/10/98 & 2146 & 7.80 & 8.01 & 123 & 11.0 & $<10$ & 80 \\
\hline 09/10/98 & 2302 & 7.80 & 7.97 & 123 & 10.7 & $<10$ & 80 \\
\hline $09 / 11 / 98$ & 0019 & 7.90 & 8.01 & 124 & 10.3 & 10 & 90 \\
\hline $09 / 11 / 98$ & 0150 & 7.96 & 7.99 & 124 & 9.8 & $<10$ & 70 \\
\hline $09 / 11 / 98$ & 0312 & 7.96 & 8.05 & 123 & 9.5 & $<10$ & 70 \\
\hline 09/11/98 & 0453 & 8.41 & 8.01 & 123 & 9.1 & $<10$ & 80 \\
\hline \multicolumn{8}{|c|}{ Site SW24L, Georgetown Lake outflow } \\
\hline 09/10/98 & 1333 & 8.04 & 8.70 & 119 & 13.9 & $<10$ & 200 \\
\hline 09/10/98 & 1452 & 7.89 & 8.90 & 118 & 13.6 & 10 & 210 \\
\hline 09/10/98 & 1604 & 8.12 & 8.93 & 117 & 13.6 & $<10$ & 210 \\
\hline 09/10/98 & 1714 & 8.17 & 8.93 & 117 & 13.6 & $<10$ & 200 \\
\hline 09/10/98 & 1827 & 8.11 & 8.98 & 119 & 13.9 & 10 & 210 \\
\hline 09/10/98 & 1958 & 7.97 & 8.87 & 119 & 13.8 & $<10$ & 210 \\
\hline 09/10/98 & 2111 & 8.00 & 8.95 & 119 & 13.9 & $<10$ & 200 \\
\hline 09/10/98 & 2226 & 8.05 & 8.88 & 119 & 13.8 & $<10$ & 200 \\
\hline 09/10/98 & 2344 & 7.95 & 8.98 & 119 & 13.7 & $<10$ & 200 \\
\hline $09 / 11 / 98$ & 0108 & 7.85 & 8.86 & 119 & 13.6 & 10 & 200 \\
\hline $09 / 11 / 98$ & 0232 & 7.81 & 8.81 & 117 & 13.6 & $<10$ & 200 \\
\hline $09 / 11 / 98$ & 0400 & 7.82 & 8.83 & 119 & 13.4 & $<10$ & 200 \\
\hline
\end{tabular}

transported into and out of the reservoir in particulate form. Excluding the anomalous concentration for the inflow sample collected on December 4, 1997, most concentrations of total recoverable lead for outflow samples exceeded those for inflow samples, indicating that the reservoir contributed particulate lead to Clear Creek during most of the sampling period. Larger concentrations of both dissolved and total recoverable lead in inflow water than in outflow water on June 1, 1998, indicate that Clear Creek supplied the reservoir with lead during peak discharge.
Except for the total recoverable outflow sample collected on January 8, 1998, concentrations of dissolved manganese were similar to concentrations of total recoverable manganese for inflow and outflow samples (fig. 18), indicating that most of the manganese in both sample sets was dissolved (or possibly colloidal). Greater concentrations of dissolved and total recoverable manganese in outflow samples for most of the sampling period, including during snowmelt, indicate that reservoir sediment supplied manganese to Clear Creek. This conclusion is consistent with 

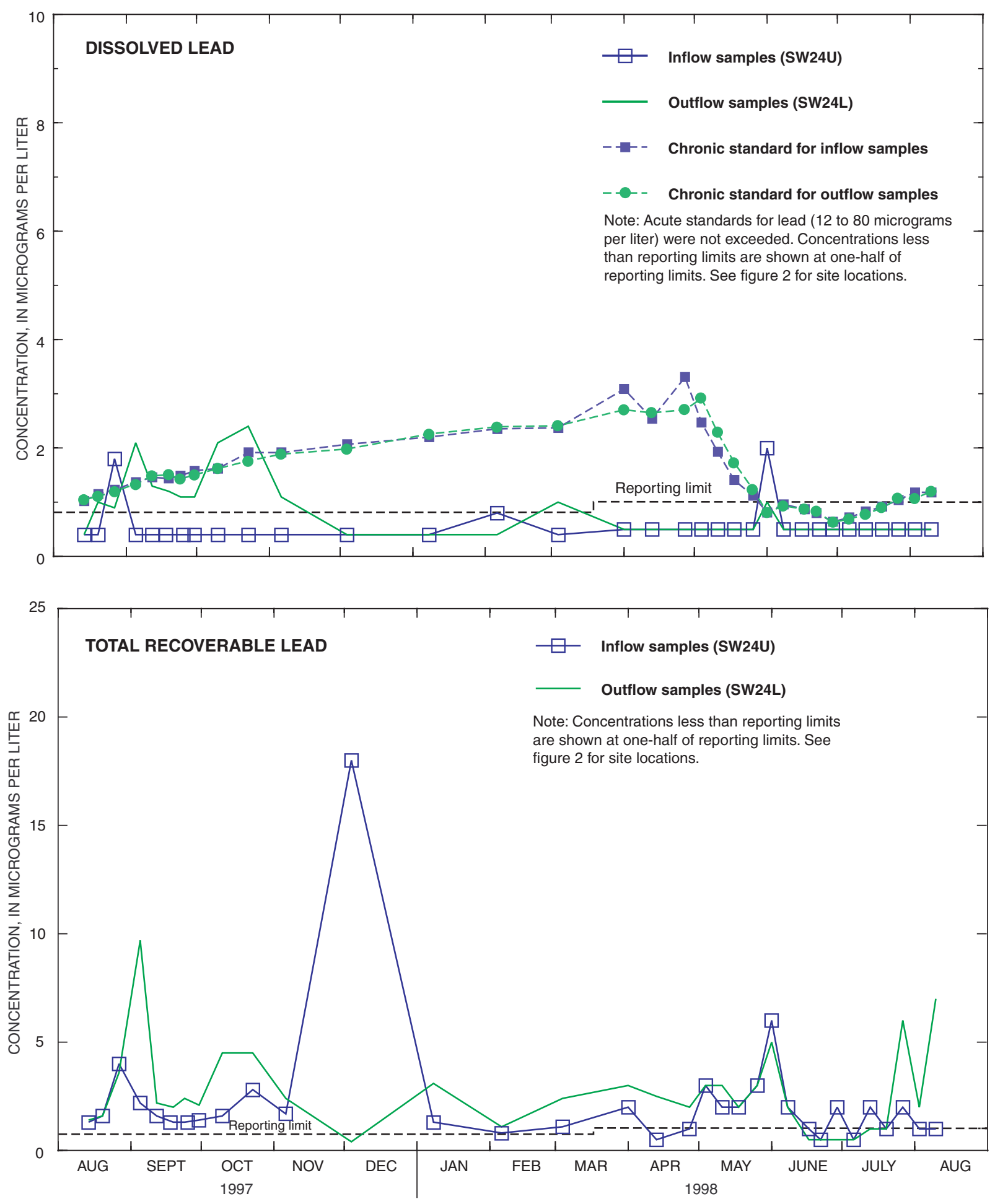

Figure 17. Dissolved and total recoverable lead concentrations in Georgetown Lake inflow and outflow samples, 1997-98. 

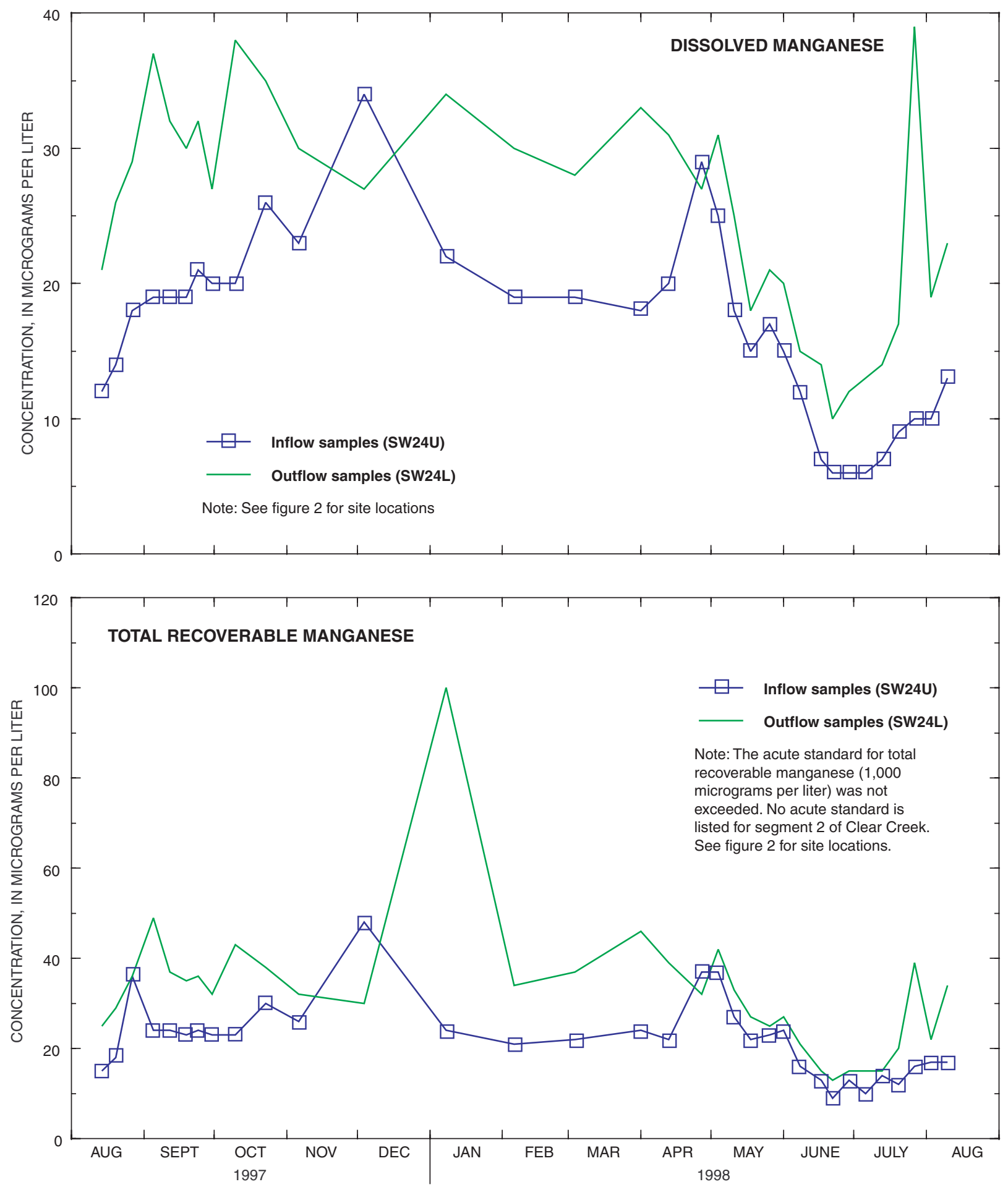

Figure 18. Dissolved and total recoverable manganese concentrations in Georgetown Lake inflow and outflow samples, 1997-98. 
the higher concentrations of total recoverable manganese in reservoir-profile samples nearest the reservoir bottom compared to samples nearest the top on March 11-12, 1998 (fig. 11).

Dissolved and total recoverable zinc concentrations for inflow and outflow samples (fig. 19) were similar during most of the sampling period, indicating that most zinc was in dissolved form. The fraction of dissolved zinc for outflow samples decreased substantially during March through mid-May 1998, although it remained more than 50 percent of the total recoverable concentrations. This period of time was characterized by large dissolved zinc concentrations in inflow water, generally high $\mathrm{pH}$ (fig. 12), and relatively high alkalinity (table 9), conditions favorable for precipitation of zinc hydroxides and carbonates. Larger concentrations of total recoverable zinc than dissolved zinc in outflow samples during this period probably resulted from contributions of colloidal, microcrystalline, and sorbed zinc in the total recoverable samples.

Inflow samples had substantially larger concentrations of dissolved and total recoverable zinc than outflow samples had except during June-August 1998 for dissolved samples and May-August 1998 for total recoverable samples, indicating that the reservoir was a sink for zinc except during snowmelt runoff, when inflow and outflow maintained similar and low concentrations of both forms of zinc. Possible mechanisms for removal of zinc by the reservoir include mineral precipitation, sorption onto mineral surfaces (Hem, 1985), and sorption in organic material (Moore, 1991) in bottom sediment. These processes were favored by longer average residence time during September 1997 through April 1998.

The chronic standard for dissolved zinc in segment 2 of Clear Creek $(200 \mu \mathrm{g} / \mathrm{L})$ exceeds the calculated acute standard (fig. 19). When the calculated acute standard is less than the chronic standard, the chronic value is used as the acute standard (Colorado Department of Public Health and Environment, 1999b). Dissolved zinc concentrations in inflow samples exceeded the chronic standard during September 1997 through May 1998; in outflow samples, dissolved zinc concentrations exceeded the chronic standard during October 1997 through May 1998. Dissolved zinc concentrations exceeded the USEPA's chronic water-quality criteria of 36-96 $\mu \mathrm{g} / \mathrm{L}$ (depending on hardness) in inflow and outflow samples over the entire sampling period.

\section{Nutrients}

Total nitrite plus nitrate concentrations (fig. 20) were slightly higher in inflow samples than outflow samples (except during early snowmelt, when dilution reduced concentrations to below the reporting limit). Algae and other aquatic plants in the reservoir use nitrite and nitrate as nutrients. Decreases in concentrations of total nitrite plus nitrate with depth at all six reservoir-profile sites during March 11-12, 1998 (table 6), when the reservoir was covered with ice, are consistent with this process. Concentrations of total phosphorus (fig. 20), another nutrient for plant growth, were small in the reservoir. Because nearly all of the measured concentrations were near or at the reporting limit, further conclusions cannot be drawn. The greater number of detections of total phosphorus after April 1, 1998, probably resulted from the decrease in reporting limit.

\section{Changes in Constituent Loads in Clear Creek}

Constituent loads for the inflow and outflow of Georgetown Lake were estimated using the mean daily discharge (fig. 3) and the total recoverable constituent concentrations (tables 8 and 9). Loads were determined for cadmium, copper, iron, lead, manganese, zinc, and nitrite plus nitrate. Nitrite plus nitrate loads were calculated because of the importance of this constituent to downstream water users. Estimated daily loads for these constituents are provided in table 11 for inflow samples and in table 12 for outflow samples.

To estimate total annual loads, the individual sample loads (tables 11 and 12) for each selected constituent were plotted against time for a 1-year period. A cubic function was fitted through the data points, and the area under the curve was integrated to determine annual loads (table 13).

Estimated total annual loads (table 13) indicate that outflow loads were smaller than inflow loads by about 21 percent for cadmium and 11 percent for zinc. Outflow loads were larger than inflow loads by about 18 percent for copper, 13 percent for iron, 1 percent for lead, and 27 percent for manganese. Outflow load of nitrite plus nitrate was about 14 percent less than inflow load, probably because of plant uptake. 

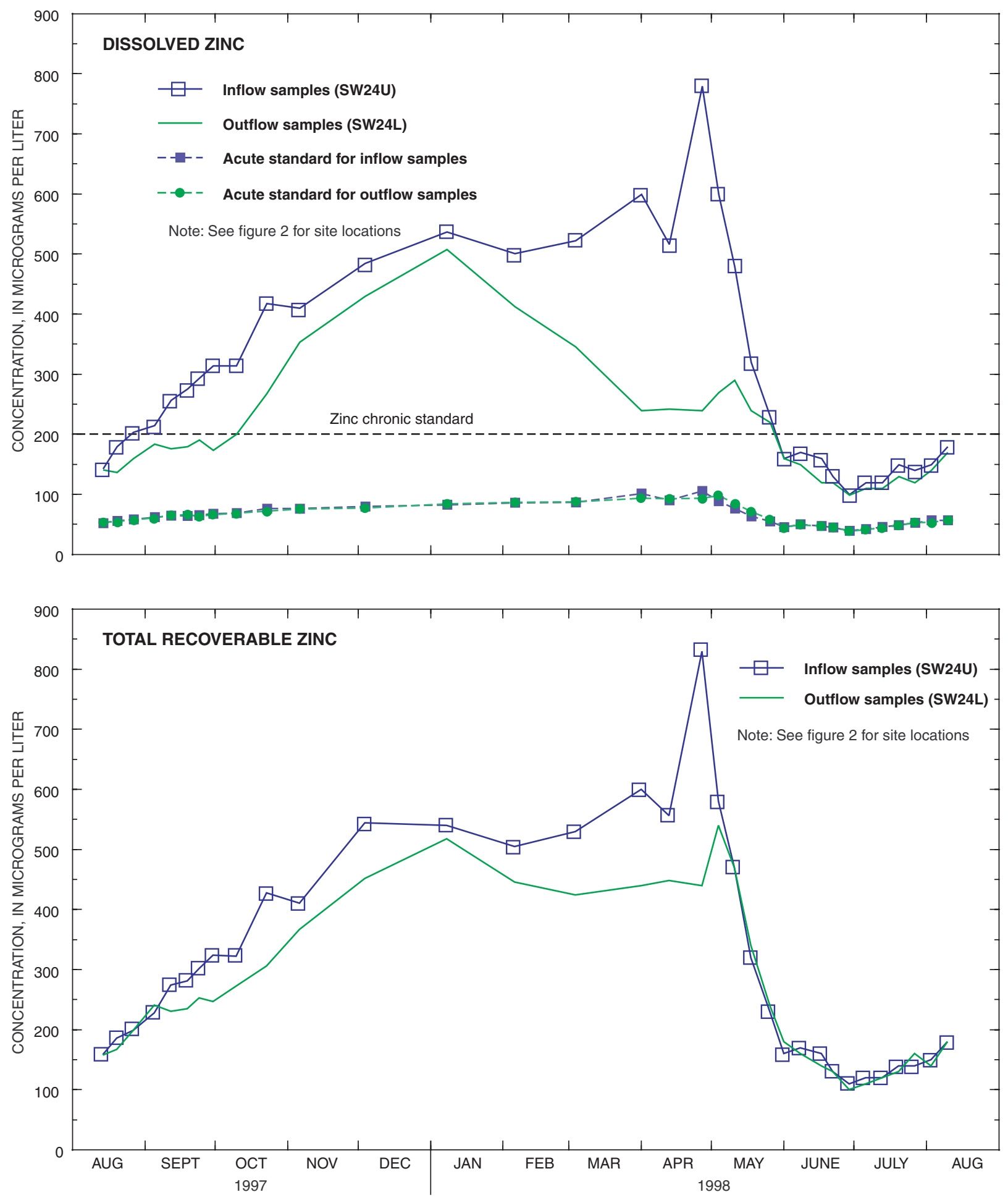

Figure 19. Dissolved and total recoverable zinc concentrations in Georgetown Lake inflow and outflow samples, 1997-98. 

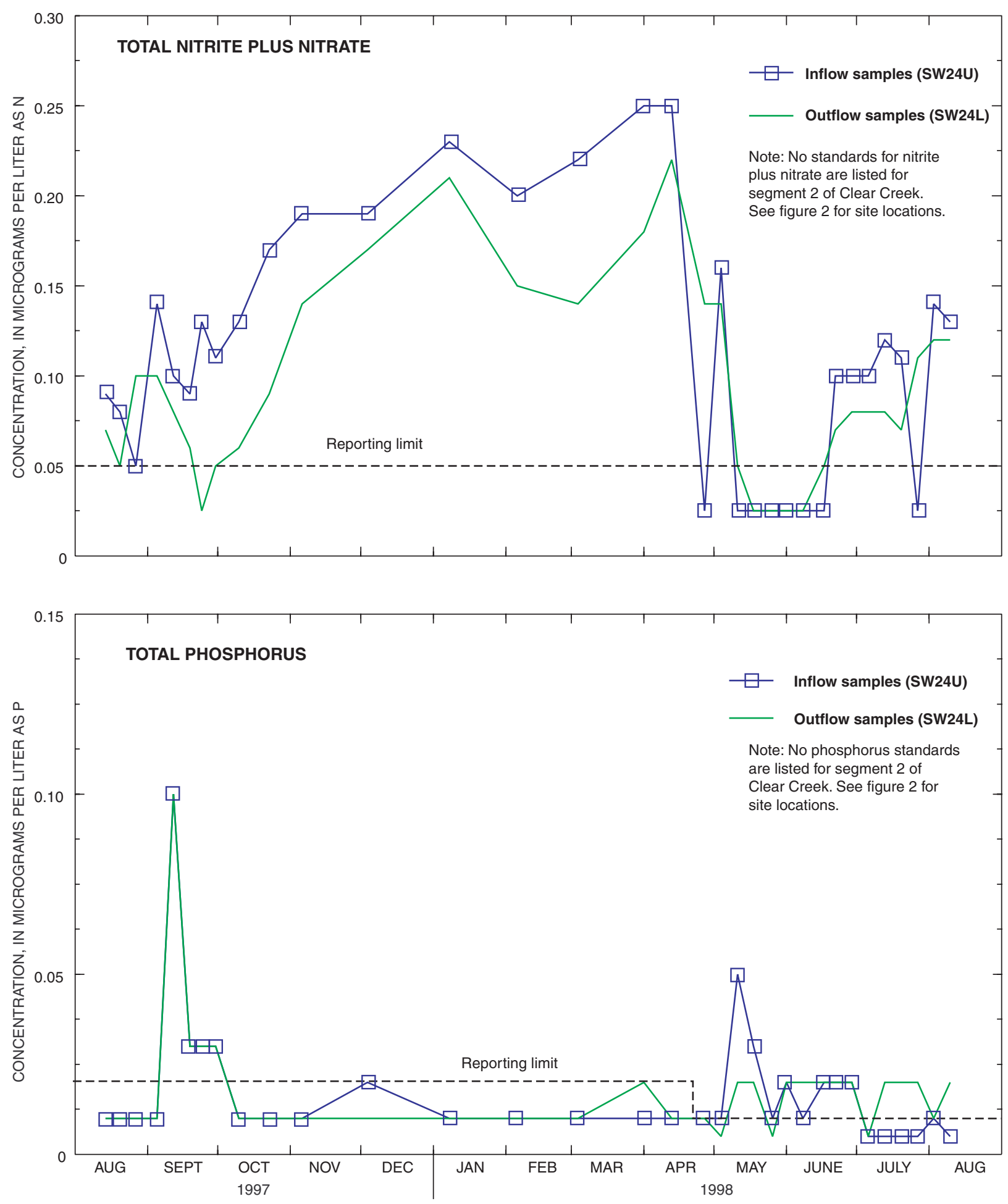

Figure 20. Total nitrite plus nitrate and total phosphorus concentrations in Georgetown Lake inflow and outflow samples, 1997-98. 
Table 11. Estimated total recoverable loads for selected metals and nitrite plus nitrate for Clear Creek at Georgetown Lake inflow, site SW24U, 1997-98

[Highlighting indicates loads calculated using one-half the reporting limit when sample concentration was below the reporting limit; $\mathrm{ft}^{3} / \mathrm{s}$, cubic feet per second; kg/d, kilograms per day; see figure 2 for location of site SW24U]

\begin{tabular}{|c|c|c|c|c|c|c|c|c|c|}
\hline \multirow[b]{2}{*}{$\begin{array}{l}\text { Sampling } \\
\text { date }\end{array}$} & \multirow[b]{2}{*}{$\begin{array}{c}\text { Discharge }{ }^{1} \\
\quad\left(\mathrm{ft}^{3} / \mathrm{s}\right)\end{array}$} & \multirow[b]{2}{*}{$\begin{array}{c}\text { Discharge }{ }^{1} \\
\text { (liters per } \\
\text { second) }\end{array}$} & \multicolumn{7}{|c|}{ Estimated load } \\
\hline & & & $\begin{array}{c}\text { Cadmium } \\
(\mathrm{kg} / \mathrm{d})\end{array}$ & $\begin{array}{c}\text { Copper } \\
\text { (kg/d) }\end{array}$ & $\begin{array}{l}\text { Iron } \\
(\mathrm{kg} / \mathrm{d})\end{array}$ & $\begin{array}{l}\text { Lead } \\
(\mathrm{kg} / \mathrm{d})\end{array}$ & $\begin{array}{l}\text { Manganese } \\
(\mathrm{kg} / \mathrm{d})\end{array}$ & $\begin{array}{l}\text { Zinc } \\
(\mathbf{k g} / \mathrm{d})\end{array}$ & $\begin{array}{l}\text { Nitrite plus } \\
\text { nitrate } \\
\text { (kg/d as N) }\end{array}$ \\
\hline $08 / 14 / 97$ & 124 & $3.51 \times 10^{3}$ & $2.43 \times 10^{-1}$ & $4.55 \times 10^{-1}$ & $3.19 \times 10^{1}$ & $3.94 \times 10^{-1}$ & 4.55 & $4.82 \times 10^{1}$ & $2.73 \times 10^{1}$ \\
\hline 08/20/97 & 101 & $2.86 \times 10^{3}$ & $2.22 \times 10^{-1}$ & $3.46 \times 10^{-1}$ & $3.16 \times 10^{1}$ & $3.95 \times 10^{-1}$ & 4.45 & $4.60 \times 10^{1}$ & $1.98 \times 10^{1}$ \\
\hline $08 / 27 / 97$ & 94 & $2.66 \times 10^{3}$ & $1.61 \times 10^{-1}$ & $4.60 \times 10^{-1}$ & $8.67 \times 10^{1}$ & $9.20 \times 10^{-1}$ & 8.28 & $4.58 \times 10^{1}$ & $1.15 \times 10^{1}$ \\
\hline 09/05/97 & 77 & $2.18 \times 10^{3}$ & $4.71 \times 10^{-2}$ & $2.07 \times 10^{-1}$ & $2.81 \times 10^{1}$ & $4.14 \times 10^{-1}$ & 4.52 & $4.30 \times 10^{1}$ & $2.64 \times 10^{1}$ \\
\hline 09/12/97 & ${ }^{2} 64$ & $1.81 \times 10^{3}$ & $9.39 \times 10^{-2}$ & $1.25 \times 10^{-1}$ & $2.47 \times 10^{1}$ & $2.51 \times 10^{-1}$ & 3.76 & $4.29 \times 10^{1}$ & $1.57 \times 10^{1}$ \\
\hline 09/19/97 & 53 & $1.50 \times 10^{3}$ & $6.48 \times 10^{-2}$ & $1.04 \times 10^{-1}$ & $1.27 \times 10^{1}$ & $1.69 \times 10^{-1}$ & 2.98 & $3.64 \times 10^{1}$ & $1.17 \times 10^{1}$ \\
\hline 09/24/97 & 52 & $1.47 \times 10^{3}$ & $7.63 \times 10^{-2}$ & $1.14 \times 10^{-1}$ & $1.36 \times 10^{1}$ & $1.65 \times 10^{-1}$ & 3.05 & $3.84 \times 10^{1}$ & $1.65 \times 10^{1}$ \\
\hline 09/30/97 & 44 & $1.25 \times 10^{3}$ & $7.54 \times 10^{-2}$ & $1.08 \times 10^{-1}$ & 9.90 & $1.51 \times 10^{-1}$ & 2.48 & $3.49 \times 10^{1}$ & $1.18 \times 10^{1}$ \\
\hline $10 / 10 / 97$ & 40 & $1.13 \times 10^{3}$ & $8.81 \times 10^{-2}$ & $7.83 \times 10^{-2}$ & 8.42 & $1.57 \times 10^{-1}$ & 2.25 & $3.15 \times 10^{1}$ & $1.27 \times 10^{1}$ \\
\hline $10 / 23 / 97$ & 28 & $7.93 \times 10^{2}$ & $7.54 \times 10^{-2}$ & $7.54 \times 10^{-2}$ & 7.26 & $1.92 \times 10^{-1}$ & 2.06 & $2.93 \times 10^{1}$ & $1.16 \times 10^{1}$ \\
\hline $11 / 06 / 97$ & 32 & $9.06 \times 10^{2}$ & $7.83 \times 10^{-2}$ & $7.83 \times 10^{-2}$ & 8.46 & $1.33 \times 10^{-1}$ & 2.04 & $3.22 \times 10^{1}$ & $1.49 \times 10^{1}$ \\
\hline $12 / 04 / 97$ & ${ }^{2} 23$ & $6.51 \times 10^{2}$ & $1.18 \times 10^{-1}$ & $1.12 \times 10^{-1}$ & $2.12 \times 10^{1}$ & 1.02 & 2.70 & $3.06 \times 10^{1}$ & $1.07 \times 10^{1}$ \\
\hline 01/08/98 & ${ }^{2} 20$ & $5.66 \times 10^{2}$ & $7.34 \times 10^{-2}$ & $1.96 \times 10^{-2}$ & 3.52 & $6.36 \times 10^{-2}$ & 1.17 & $2.64 \times 10^{1}$ & $1.13 \times 10^{1}$ \\
\hline 02/06/98 & ${ }^{2} 13$ & $3.68 \times 10^{2}$ & $5.41 \times 10^{-2}$ & $1.27 \times 10^{-2}$ & 1.37 & $2.54 \times 10^{-2}$ & $6.68 \times 10^{-1}$ & $1.61 \times 10^{1}$ & 6.36 \\
\hline 03/04/98 & ${ }^{2} 14$ & $3.96 \times 10^{2}$ & $5.82 \times 10^{-2}$ & $1.37 \times 10^{-2}$ & 2.09 & $3.77 \times 10^{-2}$ & $7.54 \times 10^{-1}$ & $1.82 \times 10^{1}$ & 7.54 \\
\hline 04/01/98 & ${ }^{2} 13$ & $3.68 \times 10^{2}$ & $6.04 \times 10^{-2}$ & $6.36 \times 10^{-2}$ & 2.54 & $6.36 \times 10^{-2}$ & $7.63 \times 10^{-1}$ & $1.75 \times 10^{1}$ & 7.95 \\
\hline 04/13/98 & 16 & $4.53 \times 10^{2}$ & $6.46 \times 10^{-2}$ & $3.91 \times 10^{-2}$ & 2.96 & $1.96 \times 10^{-2}$ & $8.77 \times 10^{-1}$ & $2.18 \times 10^{1}$ & 9.67 \\
\hline 04/27/98 & 27 & $7.65 \times 10^{2}$ & $1.59 \times 10^{-1}$ & $3.30 \times 10^{-2}$ & 9.25 & $6.61 \times 10^{-2}$ & 2.44 & $4.56 \times 10^{1}$ & 1.65 \\
\hline 05/04/98 & 53 & $1.50 \times 10^{3}$ & $2.59 \times 10^{-1}$ & $2.59 \times 10^{-1}$ & $4.02 \times 10^{1}$ & $3.89 \times 10^{-1}$ & 4.80 & $7.39 \times 10^{1}$ & $2.07 \times 10^{1}$ \\
\hline 05/11/98 & 67 & $1.90 \times 10^{3}$ & $2.29 \times 10^{-1}$ & $3.28 \times 10^{-1}$ & $4.26 \times 10^{1}$ & $3.28 \times 10^{-1}$ & 4.43 & $7.70 \times 10^{1}$ & 4.10 \\
\hline 05/18/98 & 107 & $3.03 \times 10^{3}$ & $2.36 \times 10^{-1}$ & $5.24 \times 10^{-1}$ & $6.28 \times 10^{1}$ & $5.24 \times 10^{-1}$ & 5.76 & $8.38 \times 10^{1}$ & 6.54 \\
\hline 05/26/98 & 152 & $4.30 \times 10^{3}$ & $2.60 \times 10^{-1}$ & 1.12 & $6.32 \times 10^{1}$ & 1.12 & 8.55 & $8.55 \times 10^{1}$ & 9.30 \\
\hline 06/01/98 & 237 & $6.71 \times 10^{3}$ & $3.48 \times 10^{-1}$ & 1.74 & $1.39 \times 10^{2}$ & 3.48 & $1.39 \times 10^{1}$ & $9.28 \times 10^{1}$ & $1.45 \times 10^{1}$ \\
\hline 06/08/98 & 181 & $5.13 \times 10^{3}$ & $2.21 \times 10^{-1}$ & $4.43 \times 10^{-1}$ & $5.76 \times 10^{1}$ & $8.86 \times 10^{-1}$ & 7.09 & $7.53 \times 10^{1}$ & $1.11 \times 10^{1}$ \\
\hline $06 / 17 / 98$ & 172 & $4.87 \times 10^{3}$ & $2.95 \times 10^{-1}$ & $2.10 \times 10^{-1}$ & $5.05 \times 10^{1}$ & $4.21 \times 10^{-1}$ & 5.47 & $6.73 \times 10^{1}$ & $1.05 \times 10^{1}$ \\
\hline $06 / 22 / 98$ & 241 & $6.82 \times 10^{3}$ & $2.36 \times 10^{-1}$ & $2.95 \times 10^{-1}$ & $6.49 \times 10^{1}$ & $2.95 \times 10^{-1}$ & 5.31 & $7.67 \times 10^{1}$ & $5.90 \times 10^{1}$ \\
\hline 06/29/98 & 281 & $7.96 \times 10^{3}$ & $2.75 \times 10^{-1}$ & $3.44 \times 10^{-1}$ & $1.10 \times 10^{2}$ & 1.37 & 8.94 & $7.56 \times 10^{1}$ & $6.87 \times 10^{1}$ \\
\hline 07/06/98 & 247 & $6.99 \times 10^{3}$ & $1.81 \times 10^{-1}$ & $3.02 \times 10^{-1}$ & $9.67 \times 10^{1}$ & $3.02 \times 10^{-1}$ & 6.04 & $7.25 \times 10^{1}$ & $6.04 \times 10^{1}$ \\
\hline 07/13/98 & 224 & $6.34 \times 10^{3}$ & $2.19 \times 10^{-1}$ & $5.48 \times 10^{-1}$ & $8.22 \times 10^{1}$ & 1.10 & 7.67 & $6.58 \times 10^{1}$ & $6.58 \times 10^{1}$ \\
\hline 07/20/98 & 157 & $4.45 \times 10^{3}$ & $1.54 \times 10^{-1}$ & $1.92 \times 10^{-1}$ & $3.07 \times 10^{1}$ & $3.84 \times 10^{-1}$ & 4.61 & $5.38 \times 10^{1}$ & $4.23 \times 10^{1}$ \\
\hline 07/27/98 & 175 & $4.96 \times 10^{3}$ & $1.71 \times 10^{-1}$ & $4.28 \times 10^{-1}$ & $7.71 \times 10^{1}$ & $8.56 \times 10^{-1}$ & 6.85 & $5.99 \times 10^{1}$ & $1.07 \times 10^{1}$ \\
\hline 08/03/98 & 161 & $4.56 \times 10^{3}$ & $1.97 \times 10^{-1}$ & $3.94 \times 10^{-1}$ & $5.91 \times 10^{1}$ & $3.94 \times 10^{-1}$ & 6.70 & $5.91 \times 10^{1}$ & $5.51 \times 10^{1}$ \\
\hline 08/10/98 & 135 & $3.82 \times 10^{3}$ & $1.32 \times 10^{-1}$ & $1.65 \times 10^{-1}$ & $3.63 \times 10^{1}$ & $3.30 \times 10^{-1}$ & 5.61 & $5.95 \times 10^{1}$ & $4.29 \times 10^{1}$ \\
\hline
\end{tabular}


[Highlighting indicates loads calculated using one-half the reporting limit when sample concentration was below the reporting limit; $\mathrm{ft}^{3} / \mathrm{s}$, cubic feet per second; $\mathrm{kg} / \mathrm{d}$, kilograms per day; see figure 2 for location of site SW24L]

\begin{tabular}{|c|c|c|c|c|c|c|c|c|c|}
\hline \multirow[b]{2}{*}{$\begin{array}{l}\text { Sampling } \\
\text { date }\end{array}$} & \multirow[b]{2}{*}{$\begin{array}{c}\text { Discharge }^{1} \\
\quad\left(\mathrm{ft}^{3} / \mathrm{s}\right)\end{array}$} & \multirow[b]{2}{*}{$\begin{array}{l}\text { Discharge } \\
\text { (liters per } \\
\text { second) }\end{array}$} & \multicolumn{7}{|c|}{ Estimated load } \\
\hline & & & $\begin{array}{l}\text { Cadmium } \\
(\mathrm{kg} / \mathrm{d})\end{array}$ & $\begin{array}{c}\text { Copper } \\
\text { (kg/d) }\end{array}$ & $\begin{array}{l}\text { Iron } \\
\text { (kg/d) }\end{array}$ & $\begin{array}{l}\text { Lead } \\
(\mathrm{kg} / \mathrm{d})\end{array}$ & $\begin{array}{l}\text { Manganese } \\
(\mathrm{kg} / \mathrm{d})\end{array}$ & $\begin{array}{l}\text { Zinc } \\
(\mathrm{kg} / \mathrm{d})\end{array}$ & $\begin{array}{c}\text { Nitrite } \\
\text { plus } \\
\text { nitrate } \\
\text { (kg/d as } \mathrm{N})\end{array}$ \\
\hline 08/14/97 & 113 & $3.20 \times 10^{3}$ & $1.94 \times 10^{-1}$ & $6.36 \times 10^{-1}$ & $3.82 \times 10^{1}$ & $3.87 \times 10^{-1}$ & 6.91 & $4.37 \times 10^{1}$ & $1.94 \times 10^{1}$ \\
\hline 08/20/97 & 93 & $2.63 \times 10^{3}$ & $1.37 \times 10^{-1}$ & $3.64 \times 10^{-1}$ & $3.41 \times 10^{1}$ & $3.64 \times 10^{-1}$ & 6.60 & $3.80 \times 10^{1}$ & $1.14 \times 10^{1}$ \\
\hline 08/27/97 & 85 & $2.41 \times 10^{3}$ & $1.66 \times 10^{-1}$ & $3.74 \times 10^{-1}$ & $4.64 \times 10^{1}$ & $7.49 \times 10^{-1}$ & 7.49 & $4.14 \times 10^{1}$ & $2.08 \times 10^{1}$ \\
\hline 09/05/97 & 74 & $2.10 \times 10^{3}$ & $4.53 \times 10^{-2}$ & $6.16 \times 10^{-1}$ & $6.77 \times 10^{1}$ & 1.76 & 8.87 & $4.36 \times 10^{1}$ & $1.81 \times 10^{1}$ \\
\hline 09/12/97 & 60 & $1.70 \times 10^{3}$ & $3.67 \times 10^{-2}$ & $2.20 \times 10^{-1}$ & $2.99 \times 10^{1}$ & $3.23 \times 10^{-1}$ & 5.43 & $3.39 \times 10^{1}$ & $1.17 \times 10^{1}$ \\
\hline 09/19/97 & 54 & $1.53 \times 10^{3}$ & $3.07 \times 10^{-2}$ & $2.38 \times 10^{-1}$ & $2.79 \times 10^{1}$ & $2.64 \times 10^{-1}$ & 4.62 & $3.10 \times 10^{1}$ & 7.93 \\
\hline 09/24/97 & 50 & $1.42 \times 10^{3}$ & $3.06 \times 10^{-2}$ & $1.22 \times 10^{-1}$ & $2.76 \times 10^{1}$ & $2.94 \times 10^{-1}$ & 4.40 & $3.09 \times 10^{1}$ & 3.06 \\
\hline 09/30/97 & 44 & $1.25 \times 10^{3}$ & $2.69 \times 10^{-2}$ & $3.88 \times 10^{-1}$ & $2.28 \times 10^{1}$ & $2.26 \times 10^{-1}$ & 3.44 & $2.66 \times 10^{1}$ & 5.38 \\
\hline $10 / 10 / 97$ & 43 & $1.22 \times 10^{3}$ & $2.63 \times 10^{-2}$ & $9.47 \times 10^{-2}$ & $2.69 \times 10^{1}$ & $4.73 \times 10^{-1}$ & 4.52 & $2.87 \times 10^{1}$ & 6.31 \\
\hline $10 / 23 / 97$ & 34 & $9.63 \times 10^{2}$ & $4.99 \times 10^{-2}$ & $7.49 \times 10^{-2}$ & $1.39 \times 10^{1}$ & $3.74 \times 10^{-1}$ & 3.16 & $2.55 \times 10^{1}$ & 7.49 \\
\hline $11 / 06 / 97$ & 24 & $6.80 \times 10^{2}$ & $2.94 \times 10^{-2}$ & $1.06 \times 10^{-1}$ & $1.30 \times 10^{1}$ & $1.41 \times 10^{-1}$ & 1.88 & $2.15 \times 10^{1}$ & 8.22 \\
\hline $12 / 04 / 97$ & 18 & $5.10 \times 10^{2}$ & $7.05 \times 10^{-2}$ & $1.76 \times 10^{-2}$ & 5.72 & $1.76 \times 10^{-2}$ & 1.32 & $1.99 \times 10^{1}$ & 7.49 \\
\hline 01/08/98 & 14 & $3.96 \times 10^{2}$ & $4.45 \times 10^{-2}$ & $1.37 \times 10^{-2}$ & 8.36 & $1.06 \times 10^{-1}$ & 3.43 & $1.77 \times 10^{1}$ & 7.19 \\
\hline 02/06/98 & 15 & $4.25 \times 10^{2}$ & $4.77 \times 10^{-2}$ & $1.47 \times 10^{-2}$ & 9.76 & $4.04 \times 10^{-2}$ & 1.25 & $1.64 \times 10^{1}$ & 5.50 \\
\hline 03/04/98 & 16 & $4.53 \times 10^{2}$ & $5.48 \times 10^{-2}$ & $1.57 \times 10^{-2}$ & $1.56 \times 10^{1}$ & $9.39 \times 10^{-2}$ & 1.45 & $1.66 \times 10^{1}$ & 5.48 \\
\hline 04/01/98 & 10 & $2.83 \times 10^{2}$ & $2.94 \times 10^{-2}$ & $1.22 \times 10^{-2}$ & 6.36 & $7.34 \times 10^{-2}$ & 1.13 & $1.03 \times 10^{1}$ & 4.40 \\
\hline 04/13/98 & 18 & $5.10 \times 10^{2}$ & $5.33 \times 10^{-2}$ & $4.40 \times 10^{-2}$ & $1.28 \times 10^{1}$ & $1.11 \times 10^{-1}$ & 1.72 & $1.97 \times 10^{1}$ & 9.56 \\
\hline 04/27/98 & 24 & $6.80 \times 10^{2}$ & $5.87 \times 10^{-2}$ & $2.94 \times 10^{-2}$ & $1.12 \times 10^{1}$ & $1.17 \times 10^{-1}$ & 1.88 & $2.06 \times 10^{1}$ & 8.22 \\
\hline 05/04/98 & 43 & $1.22 \times 10^{3}$ & $1.68 \times 10^{-1}$ & $1.05 \times 10^{-1}$ & $2.42 \times 10^{1}$ & $3.16 \times 10^{-1}$ & 4.42 & $5.68 \times 10^{1}$ & $1.47 \times 10^{1}$ \\
\hline 05/11/98 & 62 & $1.76 \times 10^{3}$ & $1.82 \times 10^{-1}$ & $3.03 \times 10^{-1}$ & $3.19 \times 10^{1}$ & $4.55 \times 10^{-1}$ & 5.01 & $7.13 \times 10^{1}$ & 7.58 \\
\hline 05/18/98 & 90 & $2.55 \times 10^{3}$ & $2.20 \times 10^{-1}$ & $4.40 \times 10^{-1}$ & $4.40 \times 10^{1}$ & $4.40 \times 10^{-1}$ & 5.95 & $7.49 \times 10^{1}$ & 5.50 \\
\hline 05/26/98 & 142 & $4.02 \times 10^{3}$ & $2.43 \times 10^{-1}$ & 1.04 & $5.21 \times 10^{1}$ & 1.04 & 8.69 & $8.34 \times 10^{1}$ & 8.69 \\
\hline 06/01/98 & 242 & $6.85 \times 10^{3}$ & $3.55 \times 10^{-1}$ & 1.78 & $1.36 \times 10^{2}$ & 2.96 & $1.60 \times 10^{1}$ & $1.07 \times 10^{2}$ & $1.48 \times 10^{1}$ \\
\hline 06/08/98 & 191 & $5.41 \times 10^{3}$ & $2.80 \times 10^{-1}$ & $9.35 \times 10^{-1}$ & $4.67 \times 10^{1}$ & $9.35 \times 10^{-1}$ & 9.81 & $7.48 \times 10^{1}$ & $1.17 \times 10^{1}$ \\
\hline 06/17/98 & 156 & $4.42 \times 10^{3}$ & $1.53 \times 10^{-1}$ & $1.91 \times 10^{-1}$ & $3.82 \times 10^{1}$ & $1.91 \times 10^{-1}$ & 5.72 & $5.34 \times 10^{1}$ & $1.91 \times 10^{1}$ \\
\hline 06/22/98 & 204 & $5.78 \times 10^{3}$ & $2.50 \times 10^{-1}$ & $2.50 \times 10^{-1}$ & $5.49 \times 10^{1}$ & $2.50 \times 10^{-1}$ & 6.49 & $6.49 \times 10^{1}$ & $3.49 \times 10^{1}$ \\
\hline 06/29/98 & 341 & $9.66 \times 10^{3}$ & $2.50 \times 10^{-1}$ & $8.34 \times 10^{-1}$ & $1.25 \times 10^{2}$ & $4.17 \times 10^{-1}$ & $1.25 \times 10^{1}$ & $8.34 \times 10^{1}$ & $6.67 \times 10^{1}$ \\
\hline 07/06/98 & 371 & $1.05 \times 10^{4}$ & $2.72 \times 10^{-1}$ & $4.54 \times 10^{-1}$ & $8.17 \times 10^{1}$ & $4.54 \times 10^{-1}$ & $1.36 \times 10^{1}$ & $9.98 \times 10^{1}$ & $7.26 \times 10^{1}$ \\
\hline 07/13/98 & 289 & $8.18 \times 10^{3}$ & $2.83 \times 10^{-1}$ & $7.07 \times 10^{-1}$ & $8.48 \times 10^{1}$ & $7.07 \times 10^{-1}$ & $1.06 \times 10^{1}$ & $8.48 \times 10^{1}$ & $5.66 \times 10^{1}$ \\
\hline 07/20/98 & 140 & $3.96 \times 10^{3}$ & $1.37 \times 10^{-1}$ & $3.43 \times 10^{-1}$ & $3.43 \times 10^{1}$ & $3.43 \times 10^{-1}$ & 6.85 & $4.45 \times 10^{1}$ & $2.40 \times 10^{1}$ \\
\hline 07/27/98 & 166 & $4.70 \times 10^{3}$ & $2.03 \times 10^{-1}$ & $8.12 \times 10^{-1}$ & $1.46 \times 10^{2}$ & 2.43 & $1.58 \times 10^{1}$ & $6.50 \times 10^{1}$ & $4.47 \times 10^{1}$ \\
\hline 08/03/98 & 154 & $4.36 \times 10^{3}$ & $1.51 \times 10^{-1}$ & $3.77 \times 10^{-1}$ & $5.65 \times 10^{1}$ & $7.54 \times 10^{-1}$ & 8.29 & $5.27 \times 10^{1}$ & $4.52 \times 10^{1}$ \\
\hline 08/10/98 & 121 & $3.43 \times 10^{3}$ & $1.18 \times 10^{-1}$ & $5.92 \times 10^{-1}$ & $1.01 \times 10^{2}$ & 2.07 & $1.01 \times 10^{1}$ & $5.33 \times 10^{1}$ & $3.55 \times 10^{1}$ \\
\hline
\end{tabular}


Table 13. Estimated annual total recoverable loads of selected metals and nitrite plus nitrate to and from Georgetown Lake, 1997-98

[kg/y, kilograms per year; --, not applicable]

\begin{tabular}{|c|c|c|c|c|c|c|}
\hline \multirow[b]{2}{*}{ Analyte } & \multicolumn{2}{|c|}{ Estimated load } & \multirow{2}{*}{$\begin{array}{l}\text { Net load to } \\
\text { reservoir } \\
(\mathrm{kg} / \mathrm{y})\end{array}$} & \multirow{2}{*}{$\begin{array}{l}\text { Net load from } \\
\text { reservoir } \\
(\mathrm{kg} / \mathrm{y})\end{array}$} & \multirow{2}{*}{$\begin{array}{l}\text { Net load as } \\
\text { percentage of } \\
\text { inflow load }\end{array}$} & \multirow{2}{*}{$\begin{array}{l}\text { Net load as } \\
\text { percentage of } \\
\text { outflow load }\end{array}$} \\
\hline & $\begin{array}{l}\text { Inflow } \\
\text { (kg/y) }\end{array}$ & $\begin{array}{c}\text { Outflow } \\
\text { (kg/y) }\end{array}$ & & & & \\
\hline Cadmium & 46.2 & 36.5 & 9.7 & -- & 21 & -- \\
\hline Copper & 71.9 & 87.5 & -- & 15.6 & -- & 18 \\
\hline Iron & 10,100 & 11,600 & -- & 1,500 & -- & 13 \\
\hline Lead & 150 & 152 & -- & 2 & -- & 1 \\
\hline Manganese & 1,240 & 1,710 & -- & 470 & -- & 27 \\
\hline Zinc & 14,900 & 13,200 & 1,700 & -- & 11 & -- \\
\hline Nitrite plus nitrate (as N) & 6,110 & 5,260 & 850 & -- & 14 & -- \\
\hline
\end{tabular}

These annual loads were estimated based on discharges and concentrations measured on 33 days during 1 year. Year-to-year variation in discharge, especially during spring and summer snowmelt, can significantly change the amount of transported material. Streambed disturbances, slope washouts in the basin, and resuspension of bottom sediment in the reservoir by wind-generated waves adds to the potential variability of loads into and out of the reservoir.

\section{SUMMARY}

The upper Clear Creek Basin contains many abandoned gold, silver, zinc, and lead mines, many of which were dug when a mining district was established in the late 1800's. In 1983, the U.S. Environmental Protection Agency added the basin to the National Priority List of Superfund Sites because of elevated metal concentrations in Clear Creek. In 1997, the U.S. Geological Survey, in cooperation with the U.S. Environmental Protection Agency, began a study to quantify the effects of Georgetown Lake on the fate and transport of metals in Clear Creek, which flows through the reservoir. Specific objectives of the study were (1) to estimate relative contributions of metals and nutrients to Georgetown Lake by upstream tributaries; (2) to characterize bathymetry, average residence time of water, and hydrochemistry of Georgetown Lake; and (3) to determine changes in the water quality of Clear Creek caused by Georgetown Lake.

Load estimates for metals and nitrite plus nitrate indicate that Clear Creek loads to Georgetown Lake substantially exceeded those for South Clear Creek, which joins Clear Creek about 3,600 feet upstream from the reservoir, by the following factors: cadmium, 16; copper, 2.3; iron, 6.0; lead, 2.8; manganese, 3.9; zinc, 14, and nitrite plus nitrate, 5.0. Silver Gulch, a small tributary that discharges to Clear Creek about 300 feet upstream from the reservoir, contributed negligible loads of these constituents to the reservoir compared to the contributions from the main stem of Clear Creek, mainly because of low discharge.

Discharges into and out of the reservoir are essentially equal, indicating negligible storage effects. A bathymetric survey determined that the two pools of the reservoir had a combined storage capacity of about 440 acre-feet. Curves for average reservoirresidence time as a function of discharge were constructed. They indicate that average residence time was less than 1 day at highest flow. At low flow (10 cubic feet per second), average residence time was about 22 days under ice-free conditions and about 15 days with a 3 -foot-thick ice cover.

Six sediment samples collected from the bottom of Georgetown Lake contained substantial average concentrations of iron (25,500 milligrams per kilogram), aluminum (12,300 milligrams per kilogram), zinc (2,830 milligrams per kilogram), lead (618 milligrams per kilogram), and manganese (548 milligrams per kilogram). These samples also contained sulfide minerals that generally increased from the reservoir inflow (230 milligrams per kilogram as $S)$ to the outflow (1,010 milligrams per kilogram as $\mathbf{S}$ ). Four samples that were analyzed for sulfate-reducing bacteria had abundant populations. These bacteria and the odor of hydrogen sulfide when the samples were collected indicate anoxic conditions in the sediment. 
Two water samples were collected for a qualitative taxonomical identification of algae and diatoms. Most of the identified genera are common in coldwater lakes, and one identified genus of algae is known to withstand low-light conditions.

Vertical profiles of water temperature and specific conductance taken in the reservoir on July 28, 1997, indicated that the reservoir was well mixed, which can largely be attributed to the relatively large discharge (about 170 cubic feet per second) and a brief average residence time (about 1.3 days). Temperature and specific-conductance profiles taken on February 13, 1998, indicated thermal and chemical stratification in the reservoir, which was caused by an ice cover, small discharge (about 15 cubic feet per second), and a longer average residence time (about 12 days). Water temperature increased from 0.2-1.0 degrees Celsius directly beneath the ice cover to about 3.8 degrees Celsius about halfway down the water column and remained near 3.8 degrees Celsius to bottom. Profiles of $\mathrm{pH}$ and concentrations of dissolved oxygen showed that the reservoir was vertically well mixed on July 28, 1997, except for abrupt increases near the bottom at most sites that were caused by photosynthesis. On February 13, 1998, $\mathrm{pH}$ and concentrations of dissolved oxygen had greater vertical variation, and increases tended to occur higher in the water column than on July 28, 1997, with peak values generally near the top of the warmer layer of water overlying the bottom. Median pH was about 0.5 unit higher on February 13, 1998, than on July 28, 1997. On both dates, water in the reservoir was saturated to oversaturated with dissolved oxygen, although concentrations were greater during winter than during summer. Higher $\mathrm{pH}$ and concentrations of dissolved oxygen in winter largely resulted from the cumulative effects of photosynthesis caused by the longer average residence time in winter.

Samples collected from six sites on March 11-12, 1998, showed higher concentrations of cadmium and zinc directly under the ice cover of the reservoir and higher concentrations of iron, manganese, and lead near the bottom of the reservoir. These relations and analysis of inflow and outflow water indicate that reservoir sediments were a net source of iron and manganese and a net sink of cadmium and zinc.

Samples collected from reservoir outflow on March 4, 1998, showed metal concentrations and temperature that were more representative of profile samples collected from near the bottom of the reservoir than samples collected directly under the ice cover on March 11-12, 1998. This relation indicates that the chemical stratification that existed in the reservoir during March 1998 did not result from stagnation of the deeper, warmer water but resulted from photosynthesis and water-sediment interaction, processes that were rapid enough to stratify the water column as water flowed relatively slowly through the reservoir.

Samples of inflow and outflow water collected from August 1997 to August 1998 indicated that some metals were removed from inflow water by sediments in Georgetown Lake and some metals were released from the sediments to outflow water. Dissolved cadmium and dissolved lead in inflow and outflow water exceeded the State acute and chronic waterquality standards during some of the sampling period, whereas dissolved zinc exceeded both standards in inflow and outflow water during the entire sampling period. Chromium, nickel, and silver were detected in a few samples at small concentrations, which prevented conclusions about their behavior. Arsenic, selenium, and thallium were not detected in inflow or outflow water samples.

Cadmium entered and left the reservoir mostly in dissolved form. Inflow concentrations of dissolved and total recoverable cadmium generally exceeded outflow concentrations, indicating that the reservoir was a sink for cadmium, probably by sorption onto sediment.

During most of the year, reservoir sediment contributed substantial quantities of dissolved and particulate iron to outflow water, probably as colloids of ferric hydroxide. Snowmelt runoff resupplied the reservoir with dissolved and particulate iron.

Dissolved lead concentrations exceeded chronic water-quality standards slightly on several occasions. Reservoir sediment was a source of dissolved lead to Clear Creek during late summer and early fall. A substantial fraction of lead was transported into and out of the reservoir in particulate form. The reservoir generally released particulate lead to Clear Creek except during peak discharge, when Clear Creek resupplied the reservoir with particulate lead.

Most manganese in inflow and outflow water was dissolved or colloidal. Reservoir sediment supplied dissolved and total recoverable manganese to Clear Creek during most of the year, including snowmelt. 
Dissolved zinc concentrations in inflow samples exceeded the chronic standard during September 1997 through May 1998. In outflow samples, dissolved zinc exceeded the chronic standard during October 1997 through May 1998. Most zinc in inflow and outflow samples was in dissolved form. During March through mid-May 1998, the fraction of dissolved zinc declined, apparently by precipitation of zinc minerals. The reservoir was a sink for dissolved and total recoverable zinc except during snowmelt, when inflow and outflow concentrations were similar for both forms.

Reservoir outflow loads were smaller than reservoir inflow loads by about 21 percent for cadmium and 11 percent for zinc. Outflow loads were larger than inflow loads by about 18 percent for copper, 13 percent for iron, 1 percent for lead, and 27 percent for manganese. Outflow load of nitrite plus nitrate was about 14 percent less than inflow load, probably because of plant uptake.

\section{REFERENCES}

American Public Health Association, American Water Works Association, Water Environment Federation, 1989, Standard methods for the examination of water and wastewater (17th ed.): Washington, D.C., American Public Health Association, variously paginated.

1995, Standard methods for the examination of water and wastewater (19th ed.): Washington, D.C., American Public Health Association, variously paginated.

Colorado Department of Public Health and Environment, 1999a, Regulation No. 31, The basic standards and methodologies for surface water: Colorado Department of Public Health and Environment, May 30, 1999, $144 \mathrm{p}$.

1999b, Regulation No. 38, Classification and numeric standards South Platte River Basin, Laramie River Basin, Republican River Basin, Smoky Hill River Basin: Colorado Department of Public Health and Environment, June 30, 1999, 140 p.

Crowfoot, R.M., Bruce, N.L., Unruh, J.W., Steinheimer, J.T., Ritz, G.F., Smith, M.E., Steger, R.D., and O'Neill, G.B., 1999, Water resources data, Colorado, water year 1998-v. 1, Missouri River Basin, Arkansas River Basin, and Rio Grande Basin: U.S. Geological Survey Water-Data Report CO-98-1, 451 p.

Crowfoot, R.M., Paillet, A.V., Ritz, G.F., Smith, M.E., Steger, R.D., and O’Neill, G.B., 1998, Water resources data, Colorado, water year 1997—v.1, Missouri River
Basin, Arkansas River Basin, and Rio Grande Basin: U.S. Geological Survey Water-Data Report CO-97-1, 513 p.

DeNicola, D.M., 1996, Periphyton responses to temperature at different ecological levels, in Stevenson, R.J., and others, eds., Algal ecology: San Diego, Academic Press, $753 \mathrm{p}$.

Edwards, T.K., and Glysson, G.D., 1988, Field methods for measurement of fluvial sediments: U.S. Geological Survey Open-File Report 86-531, 118 p.

Farrar, J.W., and Long, H.K., 1996, Report on the U.S. Geological Survey's evaluation program for standard reference samples distributed in April 1996: T-139 (trace constituents), T-141 (trace constituents), M-138 (major constituents), $\mathrm{N}-49$ (nutrient constituents), $\mathrm{N}-50$ (nutrient constituents), $\mathrm{P}-26$ (low ionic strength constituents), and Hg-22 (mercury): U.S. Geological Survey Open-File Report 96-436, 143 p.

Hem, J.D., 1985, Study and interpretation of the chemical characteristics of natural water: U.S. Geological Survey Water-Supply Paper 2254, 263 p.

Hill, W.R., 1996, Effects of light, in Stevenson, R.J., and others, eds., Algal ecology: San Diego, Academic Press, $753 \mathrm{p}$.

Horowitz, A.J., Demas, C.R., and Fitzgerald, K.K., 1994, U.S. Geological Survey protocol for the collection and processing of surface-water samples for the subsequent determination of inorganic constituents in filtered water: U.S. Geological Survey Open-File Report 94-539, 57 p.

Moore, J.W., 1991, Inorganic contaminants of surface water, research and monitoring priorities: New York, Springer-Verlag, 334 p.

Moran, R.E., and Wentz, D.A., 1974, Effects of metal-mine drainage on water quality in selected areas of Colorado, 1972-73: Colorado Water Conservation Board Water-Resources Circular 25, 250 p.

Sawyer, C.N., and McCarty, P.L., 1978, Chemistry for environmental engineering: New York, McGraw-Hill, Inc., $532 \mathrm{p}$.

Spurr, J.E., Garrey, G.H., and Ball, S.H., 1908, Economic geology of the Georgetown quadrangle (together with the Empire District): U.S. Geological Survey Professional Paper 63, 422 p.

Wentz, D.A., 1974, Effect of mine drainage on the quality of streams in Colorado, 1971-72: Colorado Water Conservation Board Water-Resources Circular 21, $117 \mathrm{p}$.

Wetzel, R.G., 1983, Limnology: Orlando, Saunders College Publishing/Harcourt Brace College Publishers, 767 p. 
APPENDIX 
Table A1. U.S. Environmental Protection Agency Region VIII Laboratory processing and analytical requirements for Georgetown Lake samples

$\left[{ }^{\circ} \mathrm{C}\right.$, degrees Celsius; --, not applicable; $\mu \mathrm{S} / \mathrm{cm}$, microsiemens per centimeter at 25 degrees Celsius; $\mathrm{mg} / \mathrm{L}$, milligrams per liter; $\mathrm{mL}$, milliliters; $\mu \mathrm{g} / \mathrm{L}$, micrograms per liter; $\mu \mathrm{m}$, micrometers; $\mathrm{mg} / \mathrm{kg}$, milligrams per kilogram; N, normal; analytical method numbers described in table A2]

\begin{tabular}{|c|c|c|c|c|c|c|c|c|}
\hline Group & Constituent & $\begin{array}{c}\text { Units of } \\
\text { measurement }\end{array}$ & $\begin{array}{l}\text { Reporting } \\
\text { limit }\end{array}$ & Preservative $^{1}$ & $\begin{array}{c}\text { Field } \\
\text { filtration }\end{array}$ & $\begin{array}{l}\text { Holding } \\
\text { time }\end{array}$ & $\begin{array}{c}\text { Analytical } \\
\text { method number }\end{array}$ & $\begin{array}{c}\text { Container } \\
\text { type }\end{array}$ \\
\hline \multicolumn{9}{|c|}{ Field measurements } \\
\hline & Temperature & ${ }^{\circ} \mathrm{C}$ & 0.1 & -- & None & Field analysis & 170.1 & In situ or field container \\
\hline & Specific conductance & $\mu \mathrm{S} / \mathrm{cm}$ & 1 & -- & None & Field analysis & 120.1 & In situ or field container \\
\hline & $\mathrm{pH}$ & standard unit & 0.01 & -- & None & Field analysis & 150.1 & In situ or field container \\
\hline & Dissolved oxygen & $\mathrm{mg} / \mathrm{L}$ & 0.1 & -- & None & Field analysis & 360.1 & In situ or field container \\
\hline \multicolumn{9}{|c|}{ Anions, dissolved (group A) and alkalinity } \\
\hline & Fluoride & $\mathrm{mg} / \mathrm{L}$ & 0.5 & None & None & 28 days & 300 & 1-liter polyethylene bottle \\
\hline & Chloride & $\mathrm{mg} / \mathrm{L}$ & 0.2 & None & None & 28 days & 300 & 1-liter polyethylene bottle \\
\hline & Sulfate & $\mathrm{mg} / \mathrm{L}$ & 1.0 & None & None & 28 days & 300 & 1-liter polyethylene bottle \\
\hline & Residue, nonfilterable & $\mathrm{mg} / \mathrm{L}$ & 4 & None & None & 7 days & 160.2 & 1-liter polyethylene bottle \\
\hline & Alkalinity & $\mathrm{mg} / \mathrm{L}$ as $\mathrm{CaCO}_{3}$ & 5 & None & None & 14 days & 310.1 & 1-liter polyethylene bottle \\
\hline & Silica & $\mathrm{mg} / \mathrm{L}$ as $\mathrm{SiO}_{2}$ & 1 & None & None & 6 months & I-2700-85 & 1-liter polyethylene bottle \\
\hline \multicolumn{9}{|c|}{ Anions (group B) } \\
\hline & Ammonia & $\mathrm{mg} / \mathrm{L}$ as $\mathrm{N}$ & 0.05 & $5 \mathrm{~mL} \mathrm{H}_{2} \mathrm{SO}_{4}$ & None & 28 days & 350.1 & 1-liter polyethylene bottle \\
\hline & Nitrite plus nitrate & $\mathrm{mg} / \mathrm{L}$ as $\mathrm{N}$ & 0.05 & $5 \mathrm{~mL} \mathrm{H}_{2} \mathrm{SO}_{4}$ & None & 28 days & 353.2 & 1-liter polyethylene bottle \\
\hline & Phosphorus & $\mathrm{mg} / \mathrm{L}$ as $\mathrm{P}$ & 0.02 & $5 \mathrm{~mL} \mathrm{H}_{2} \mathrm{SO}_{4}$ & None & 28 days & $365.1 / \mathrm{I}-4600-85$ & 1-liter polyethylene bottle \\
\hline Total organ & carbon & $\mathrm{mg} / \mathrm{L}$ as $\mathrm{C}$ & 1.5 & $5 \mathrm{~mL} \mathrm{H}_{2} \mathrm{SO}_{4}$ & None & 28 days & 415.2 & 1-liter polyethylene bottle \\
\hline Dissolved c & ganic carbon & $\mathrm{mg} / \mathrm{L}$ as $\mathrm{C}$ & 1.5 & $5 \mathrm{~mL} \mathrm{H}_{2} \mathrm{SO}_{4}$ & $0.45 \mu \mathrm{m}, \mathrm{Ag}$ & 28 days & 415.2 & 1-liter polyethylene bottle \\
\hline \multicolumn{9}{|c|}{ Trace metals (dissolved) and cations } \\
\hline & Aluminum & $\mu \mathrm{g} / \mathrm{L}$ & 40 & $2 \mathrm{~mL} \mathrm{HNO}_{3}$ & $0.45 \mu \mathrm{m}$ & 6 months & 200.7 & 1-liter polyethylene bottle, acid rinsed \\
\hline & Arsenic & $\mu \mathrm{g} / \mathrm{L}$ & 1 & $2 \mathrm{~mL} \mathrm{HNO}_{3}$ & $0.45 \mu \mathrm{m}$ & 6 months & 200.9 & 1-liter polyethylene bottle, acid rinsed \\
\hline & Cadmium & $\mu \mathrm{g} / \mathrm{L}$ & 0.5 & $2 \mathrm{~mL} \mathrm{HNO}_{3}$ & $0.45 \mu \mathrm{m}$ & 6 months & 200.9 & 1-liter polyethylene bottle, acid rinsed \\
\hline & Calcium & $\mathrm{mg} / \mathrm{L}$ & 0.03 & $2 \mathrm{~mL} \mathrm{HNO}_{3}$ & $0.45 \mu \mathrm{m}$ & 6 months & 200.7 & 1-liter polyethylene bottle, acid rinsed \\
\hline & Copper & $\mu \mathrm{g} / \mathrm{L}$ & 0.8 & $2 \mathrm{~mL} \mathrm{HNO}_{3}$ & $0.45 \mu \mathrm{m}$ & 6 months & 200.9 & 1-liter polyethylene bottle, acid rinsed \\
\hline & Chromium & $\mu \mathrm{g} / \mathrm{L}$ & 0.8 & $2 \mathrm{~mL} \mathrm{HNO}_{3}$ & $0.45 \mu \mathrm{m}$ & 6 months & 200.9 & 1-liter polyethylene bottle, acid rinsed \\
\hline & Iron & $\mu \mathrm{g} / \mathrm{L}$ & 5 & $2 \mathrm{~mL} \mathrm{HNO}_{3}$ & $0.45 \mu \mathrm{m}$ & 6 months & 200.7 & 1-liter polyethylene bottle, acid rinsed \\
\hline & Lead & $\mu \mathrm{g} / \mathrm{LL}$ & 0.8 & $2 \mathrm{~mL} \mathrm{HNO}_{3}$ & $0.45 \mu \mathrm{m}$ & 6 months & 200.9 & 1-liter polyethylene bottle, acid rinsed \\
\hline & Magnesium & $\mathrm{mg} / \mathrm{L}$ & 0.05 & $2 \mathrm{~mL} \mathrm{HNO}_{3}$ & $0.45 \mu \mathrm{m}$ & 6 months & 200.7 & 1-liter polyethylene bottle, acid rinsed \\
\hline & Manganese & $\mu \mathrm{g} / \mathrm{L}$ & 1 & $2 \mathrm{~mL} \mathrm{HNO}_{3}$ & $0.45 \mu \mathrm{m}$ & 6 months & 200.7 & 1-liter polyethylene bottle, acid rinsed \\
\hline
\end{tabular}


Table A1. U.S. Environmental Protection Agency Region VIII Laboratory processing and analytical requirements for Georgetown Lake samples—Continued

$\left[{ }^{\circ} \mathrm{C}\right.$, degrees Celsius; --, not applicable; $\mu \mathrm{S} / \mathrm{cm}$, microsiemens per centimeter at 25 degrees Celsius; $\mathrm{mg} / \mathrm{L}$, milligrams per liter; $\mathrm{mL}$, milliliters; $\mu \mathrm{g} / \mathrm{L}, \mathrm{micrograms}$ per liter; $\mu \mathrm{m}$, micrometers; $\mathrm{mg} / \mathrm{kg}$, milligrams per kilogram; N, normal; analytical method numbers described in table A2]

\begin{tabular}{|c|c|c|c|c|c|c|c|c|}
\hline Group & Constituent & $\begin{array}{c}\text { Units of } \\
\text { measurement }\end{array}$ & $\begin{array}{l}\text { Reporting } \\
\text { limit }\end{array}$ & Preservative $^{1}$ & $\begin{array}{c}\text { Field } \\
\text { filtration }\end{array}$ & $\begin{array}{l}\text { Holding } \\
\text { time }\end{array}$ & $\begin{array}{c}\text { Analytical } \\
\text { method number }\end{array}$ & $\begin{array}{l}\text { Container } \\
\text { type }\end{array}$ \\
\hline \multicolumn{9}{|c|}{ Trace metals (dissolved) and cations } \\
\hline & Nickel & $\mu \mathrm{g} / \mathrm{L}$ & 11 & $2 \mathrm{~mL} \mathrm{HNO}_{3}$ & $0.45 \mu \mathrm{m}$ & 6 months & 200.7 & 1-liter polyethylene bottle, acid rinsed \\
\hline & Potassium & $\mathrm{mg} / \mathrm{L}$ & 2 & $2 \mathrm{~mL} \mathrm{HNO}_{3}$ & $0.45 \mu \mathrm{m}$ & 6 months & 200.7 & 1-liter polyethylene bottle, acid rinsed \\
\hline & Selenium & $\mu \mathrm{g} / \mathrm{L}$ & 1 & $2 \mathrm{~mL} \mathrm{HNO}_{3}$ & $0.45 \mu \mathrm{m}$ & 6 months & 200.9 & 1-liter polyethylene bottle, acid rinsed \\
\hline & Silver & $\mu \mathrm{g} / \mathrm{L}$ & 0.2 & $2 \mathrm{~mL} \mathrm{HNO}_{3}$ & $0.45 \mu \mathrm{m}$ & 6 months & 200.9 & 1-liter polyethylene bottle, acid rinsed \\
\hline & Sodium & $\mathrm{mg} / \mathrm{L}$ & 0.03 & $2 \mathrm{~mL} \mathrm{HNO}_{3}$ & $0.45 \mu \mathrm{m}$ & 6 months & 200.7 & 1-liter polyethylene bottle, acid rinsed \\
\hline & Thallium & $\mu \mathrm{g} / \mathrm{L}$ & 1.0 & $2 \mathrm{~mL} \mathrm{HNO}_{3}$ & $0.45 \mu \mathrm{m}$ & 6 months & 200.9 & 1-liter polyethylene bottle, acid rinsed \\
\hline & Zinc & $\mu \mathrm{g} / \mathrm{L}$ & 4 & $2 \mathrm{~mL} \mathrm{HNO}_{3}$ & $0.45 \mu \mathrm{m}$ & 6 months & 200.7 & 1-liter polyethylene bottle, acid rinsed \\
\hline \multicolumn{9}{|c|}{ Trace metals (total recoverable) } \\
\hline & Aluminum & $\mu \mathrm{g} / \mathrm{L}$ & 40 & $2 \mathrm{~mL} \mathrm{HNO}_{3}$ & None & 6 months & 200.7 & 1-liter polyethylene bottle, acid rinsed \\
\hline & Arsenic & $\mu \mathrm{g} / \mathrm{L}$ & 1 & $2 \mathrm{~mL} \mathrm{HNO}_{3}$ & None & 6 months & 200.9 & 1-liter polyethylene bottle, acid rinsed \\
\hline & Cadmium & $\mu \mathrm{g} / \mathrm{L}$ & 0.5 & $2 \mathrm{~mL} \mathrm{HNO}_{3}$ & None & 6 months & 200.9 & 1-liter polyethylene bottle, acid rinsed \\
\hline & Copper & $\mu \mathrm{g} / \mathrm{L}$ & 0.8 & $2 \mathrm{~mL} \mathrm{HNO}_{3}$ & None & 6 months & 200.9 & 1-liter polyethylene bottle, acid rinsed \\
\hline & Chromium & $\mu \mathrm{g} / \mathrm{L}$ & 0.8 & $2 \mathrm{~mL} \mathrm{HNO}_{3}$ & None & 6 months & 200.9 & 1-liter polyethylene bottle, acid rinsed \\
\hline & Iron & $\mu \mathrm{g} / \mathrm{L}$ & 5 & $2 \mathrm{~mL} \mathrm{HNO}_{3}$ & None & 6 months & 200.7 & 1-liter polyethylene bottle, acid rinsed \\
\hline & Lead & $\mu \mathrm{g} / \mathrm{L}$ & 0.8 & $2 \mathrm{~mL} \mathrm{HNO}_{3}$ & None & 6 months & 200.9 & 1-liter polyethylene bottle, acid rinsed \\
\hline & Manganese & $\mu \mathrm{g} / \mathrm{L}$ & 1 & $2 \mathrm{~mL} \mathrm{HNO}_{3}$ & None & 6 months & 200.7 & 1-liter polyethylene bottle, acid rinsed \\
\hline & Nickel & $\mu \mathrm{g} / \mathrm{L}$ & 11 & $2 \mathrm{~mL} \mathrm{HNO}_{3}$ & None & 6 months & 200.7 & 1-liter polyethylene bottle, acid rinsed \\
\hline & Selenium & $\mu \mathrm{g} / \mathrm{L}$ & 1 & $2 \mathrm{~mL} \mathrm{HNO}_{3}$ & None & 6 months & 200.9 & 1-liter polyethylene bottle, acid rinsed \\
\hline & Silver & $\mu \mathrm{g} / \mathrm{L}$ & 0.2 & $2 \mathrm{~mL} \mathrm{HNO}_{3}$ & None & 6 months & 200.9 & 1-liter polyethylene bottle, acid rinsed \\
\hline & Sodium & $\mu \mathrm{g} / \mathrm{L}$ & 0.03 & $2 \mathrm{~mL} \mathrm{HNO}_{3}$ & None & 6 months & 200.7 & 1-liter polyethylene bottle, acid rinsed \\
\hline & Thallium & $\mu \mathrm{g} / \mathrm{L}$ & 1.0 & $2 \mathrm{~mL} \mathrm{HNO}_{3}$ & None & 6 months & 200.9 & 1-liter polyethylene bottle, acid rinsed \\
\hline & Zinc & $\mu \mathrm{g} / \mathrm{L}$ & 4 & $2 \mathrm{~mL} \mathrm{HNO}_{3}$ & None & 6 months & 200.7 & 1-liter polyethylene bottle, acid rinsed \\
\hline \multicolumn{9}{|c|}{ Sediment samples } \\
\hline & Total metals, sediment & $\mathrm{mg} / \mathrm{kg}$ & -- & None & NA & 6 months & -- & 250-mL polyethylene jar, minimize airspace \\
\hline & Total sulfides, sediment & $\mathrm{mg} / \mathrm{kg}$ & 0.1 & $\begin{array}{l}0.5 \text { to } 2 \mathrm{~mL}, \\
2 \mathrm{~N} \text { zinc acetate }\end{array}$ & NA & 6 months & -- & 250-mL polyethylene jar, minimize airspace \\
\hline
\end{tabular}

${ }^{1}$ All samples preserved in wet ice at $4{ }^{\circ} \mathrm{C}$ for transport to the laboratory. 
Table A2. Analytical methods used for analysis of Georgetown Lake water-quality samples

[USEPA, U.S. Environmental Protection Agency; ICP, inductively coupled plasma; ICP/MS, inductively coupled plasma/mass spectroscopy; GFAA, graphite furnace atomic absorption; AA, atomic absorption; IC, ion chromatograph; AC, automated colorimetry]

\begin{tabular}{|c|c|}
\hline USEPA method number & Laboratory method \\
\hline 120.1 & Specific conductance_-electrometric \\
\hline 150.1 & $\mathrm{pH}$-electrometric \\
\hline 160.2 & Residue, non-filterable and total suspended solids \\
\hline 170.1 & Temperature—electrometric \\
\hline 200.7 & Trace elements and cations_-inductively coupled plasma (ICP) \\
\hline 200.8 & Trace elements (ICP/MS) \\
\hline 200.9 & Trace elements by graphite furnace atomic absorption (GFAA) \\
\hline 206.2 & Arsenic_-AA, furnace technique \\
\hline 213.2 & Cadmium-AA, furnace technique \\
\hline 239.2 & Lead-AA, furnace technique \\
\hline 270.2 & Selenium-AA, furnace technique \\
\hline 272.2 & Silver-AA, furnace technique \\
\hline 279.2 & Thallium-AA, furnace technique \\
\hline 300 & Chloride, fluoride, sulfate-IC \\
\hline 310.1 & Alkalinity-titrimeteric, $\mathrm{pH} 4.5$ \\
\hline 350.1 & Nitrogen, ammonia-colorimetric, titrimetric \\
\hline 353.2 & Nitrogen, nitrate-nitrite-colorimetric/cadmium \\
\hline 360.1 & Dissolved oxygen-electrometric \\
\hline 365.1 & Phosphorus-AC, ascorbic acid \\
\hline 415.1 & Organic carbon, total - combustion or oxidation \\
\hline 415.2 & Organic carbon, total—ultraviolet promoted \\
\hline I-2700-85 & Automated determination of silicon dioxide (silica) using a segmented flow analyzer \\
\hline $\mathrm{I}-4600-85$ & Semiautomated determination of total phosphorus using a segmented flow analyzer \\
\hline
\end{tabular}


๗ Table A3. Summary of U.S. Environmental Protection Agency analytical methods used for analysis of filtered samples

[Analytical method numbers described in table A2; --, no data]

\begin{tabular}{|c|c|c|c|c|c|c|c|c|c|}
\hline \multirow{3}{*}{$\begin{array}{l}\text { Sampling } \\
\text { date }\end{array}$} & \multicolumn{9}{|c|}{ Analytical method numbers } \\
\hline & \multirow{2}{*}{ Alkalinity } & \multicolumn{4}{|c|}{ Cations } & \multicolumn{3}{|c|}{ Anions } & \multirow{2}{*}{ Silica } \\
\hline & & Ca & Mg & $\mathbf{K}$ & $\mathrm{Na}$ & $\mathrm{Cl}$ & $F$ & $\mathrm{SO}_{4}$ & \\
\hline $08 / 14 / 97$ & 310.1 & 200.7 & 200.7 & 200.7 & 200.7 & 300.0 & 300.0 & 300.0 & I-2700-85 \\
\hline 08/20/97 & 310.1 & 200.7 & 200.7 & 200.7 & 200.7 & 300.0 & 300.0 & 300.0 & I-2700-85 \\
\hline 08/27/97 & 310.1 & 200.7 & 200.7 & 200.7 & 200.7 & 300.0 & 300.0 & 300.0 & I-2700-85 \\
\hline 09/05/97 & 310.1 & 200.7 & 200.7 & 200.7 & 200.7 & 300.0 & 300.0 & 300.0 & I-2700-85 \\
\hline 09/12/97 & 310.1 & 200.7 & 200.7 & 200.7 & 200.7 & 300.0 & 300.0 & 300.0 & I-2700-85 \\
\hline 09/19/97 & 310.1 & 200.7 & 200.7 & 200.7 & 200.7 & 300.0 & 300.0 & 300.0 & I-2700-85 \\
\hline $09 / 24 / 97$ & 310.1 & 200.7 & 200.7 & 200.7 & 200.7 & 300.0 & 300.0 & 300.0 & I-2700-85 \\
\hline 09/30/97 & 310.1 & 200.7 & 200.7 & 200.7 & 200.7 & 300.0 & 300.0 & 300.0 & I-2700-85 \\
\hline $10 / 10 / 97$ & 310.1 & 200.7 & 200.7 & 200.7 & 200.7 & 300.0 & 300.0 & 300.0 & $\mathrm{I}-2700-85$ \\
\hline $10 / 23 / 97$ & 310.1 & 200.7 & 200.7 & 200.7 & 200.7 & 300.0 & 300.0 & 300.0 & I-2700-85 \\
\hline $11 / 06 / 97$ & 310.1 & 200.7 & 200.7 & 200.7 & 200.7 & 300.0 & 300.0 & 300.0 & I-2700-85 \\
\hline $12 / 04 / 97$ & 310.1 & 200.7 & 200.7 & 200.7 & 200.7 & 300.0 & 300.0 & 300.0 & I-2700-85 \\
\hline 01/08/98 & 310.1 & 200.7 & 200.7 & 200.7 & 200.7 & 300.0 & 300.0 & 300.0 & $\mathrm{I}-2700-85$ \\
\hline 02/06/98 & 310.1 & 200.7 & 200.7 & 200.7 & 200.7 & 300.0 & 300.0 & 300.0 & $\mathrm{I}-2700-85$ \\
\hline 03/04/98 & 310.1 & 200.7 & 200.7 & 200.7 & 200.7 & 300.0 & 300.0 & 300.0 & I-2700-85 \\
\hline 04/01/98 & 310.1 & 200.7 & 200.7 & 200.7 & 200.7 & 300.0 & 300.0 & 300.0 & -- \\
\hline 04/13/98 & 310.1 & 200.7 & 200.7 & 200.7 & 200.7 & 300.0 & 300.0 & 300.0 & -- \\
\hline $04 / 27 / 98$ & 310.1 & 200.7 & 200.7 & 200.7 & 200.7 & 300.0 & 300.0 & 300.0 & -- \\
\hline 05/04/98 & 310.1 & 200.7 & 200.7 & 200.7 & 200.7 & 300.0 & 300.0 & 300.0 & -- \\
\hline 05/11/98 & 310.1 & 200.7 & 200.7 & 200.7 & 200.7 & 300.0 & 300.0 & 300.0 & -- \\
\hline 05/18/98 & 310.1 & 200.7 & 200.7 & 200.7 & 200.7 & 300.0 & 300.0 & 300.0 & -- \\
\hline 05/26/98 & 310.1 & 200.7 & 200.7 & 200.7 & 200.7 & 300.0 & 300.0 & 300.0 & -- \\
\hline 06/01/98 & 310.1 & 200.7 & 200.7 & 200.7 & 200.7 & 300.0 & 300.0 & 300.0 & -- \\
\hline 06/08/98 & 310.1 & 200.7 & 200.7 & 200.7 & 200.7 & 300.0 & 300.0 & 300.0 & -- \\
\hline 06/17/98 & 310.1 & 200.7 & 200.7 & 200.7 & 200.7 & 300.0 & 300.0 & 300.0 & -- \\
\hline $06 / 22 / 98$ & 310.1 & 200.7 & 200.7 & 200.7 & 200.7 & 300.0 & 300.0 & 300.0 & -- \\
\hline 06/29/98 & 310.1 & 200.7 & 200.7 & 200.7 & 200.7 & 300.0 & 300.0 & 300.0 & -- \\
\hline 07/06/98 & 310.1 & 200.7 & 200.7 & 200.7 & 200.7 & 300.0 & 300.0 & 300.0 & -- \\
\hline 07/13/98 & 310.1 & 200.7 & 200.7 & 200.7 & 200.7 & 300.0 & 300.0 & 300.0 & -- \\
\hline 07/20/98 & 310.1 & 200.7 & 200.7 & 200.7 & 200.7 & 300.0 & 300.0 & 300.0 & -- \\
\hline 07/27/98 & 310.1 & 200.7 & 200.7 & 200.7 & 200.7 & 300.0 & 300.0 & 300.0 & -- \\
\hline 08/03/98 & 310.1 & 200.7 & 200.7 & 200.7 & 200.7 & 300.0 & 300.0 & 300.0 & -- \\
\hline 08/10/98 & 310.1 & 200.7 & 200.7 & 200.7 & 200.7 & 300.0 & 300.0 & 300.0 & -- \\
\hline
\end{tabular}


Table A3. Summary of U.S. Environmental Protection Agency analytical methods used for analysis of filtered samples-Continued [Analytical method numbers described in table A2; --, no data]

\begin{tabular}{|c|c|c|c|c|c|c|c|c|c|c|c|c|c|c|}
\hline \multirow{3}{*}{$\begin{array}{l}\text { Sampling } \\
\text { date }\end{array}$} & \multicolumn{14}{|c|}{ Analytical method numbers } \\
\hline & \multicolumn{13}{|c|}{ Dissolved metals } & \multirow{2}{*}{$\begin{array}{c}\text { Dissolved } \\
\text { organic } \\
\text { carbon }\end{array}$} \\
\hline & Al & As & Cd & $\mathrm{Cr}$ & $\mathrm{Cu}$ & $\mathrm{Fe}$ & $\mathrm{Pb}$ & Mn & $\mathrm{Ni}$ & $\mathrm{Se}$ & Ag & TI & $\mathbf{Z n}$ & \\
\hline $08 / 14 / 97$ & 200.7 & 200.9 & 200.9 & 200.9 & 200.9 & 200.7 & 200.9 & 200.7 & 200.7 & 200.9 & 200.9 & 200.9 & 200.7 & 415.2 \\
\hline 08/20/97 & 200.7 & 200.9 & 200.9 & 200.9 & 200.9 & 200.7 & 200.9 & 200.7 & 200.7 & 200.9 & 200.9 & 200.9 & 200.7 & 415.2 \\
\hline 08/27/97 & 200.7 & 200.9 & 200.9 & 200.9 & 200.9 & 200.7 & 200.9 & 200.7 & 200.7 & 200.9 & 200.9 & 200.9 & 200.7 & 415.2 \\
\hline 09/05/97 & 200.7 & 200.7 & 200.9 & 200.7 & 200.9 & 200.7 & 200.9 & 200.7 & 200.7 & 200.7 & 200.7 & 200.7 & 200.7 & 415.2 \\
\hline 09/12/97 & 200.7 & 200.7 & 200.9 & 200.7 & 200.9 & 200.7 & 200.9 & 200.7 & 200.7 & 200.7 & 200.7 & 200.7 & 200.7 & 415.2 \\
\hline 09/19/97 & 200.7 & 200.7 & 200.9 & 200.7 & 200.9 & 200.7 & 200.9 & 200.7 & 200.7 & 200.7 & 200.7 & 200.7 & 200.7 & 415.2 \\
\hline $09 / 24 / 97$ & 200.7 & 200.7 & 200.9 & 200.7 & 200.9 & 200.7 & 200.9 & 200.7 & 200.7 & 200.7 & 200.7 & 200.7 & 200.7 & 415.2 \\
\hline 09/30/97 & 200.7 & 200.7 & 200.9 & 200.7 & 200.9 & 200.7 & 200.9 & 200.7 & 200.7 & 200.7 & 200.7 & 200.7 & 200.7 & 415.2 \\
\hline $10 / 10 / 97$ & 200.7 & 200.7 & 200.9 & 200.7 & 200.9 & 200.7 & 200.9 & 200.7 & 200.7 & 200.7 & 200.7 & 200.7 & 200.7 & 415.2 \\
\hline $10 / 23 / 97$ & 200.7 & 200.7 & 200.9 & 200.7 & 200.9 & 200.7 & 200.9 & 200.7 & 200.7 & 200.7 & 200.7 & 200.7 & 200.7 & 415.2 \\
\hline $11 / 06 / 97$ & 200.7 & 200.7 & 200.9 & 200.7 & 200.9 & 200.7 & 200.9 & 200.7 & 200.7 & 200.7 & 200.7 & 200.7 & 200.7 & 415.2 \\
\hline $12 / 04 / 97$ & 200.7 & 200.7 & 200.9 & 200.7 & 200.9 & 200.7 & 200.9 & 200.7 & 200.7 & 200.7 & 200.7 & 200.7 & 200.7 & 415.2 \\
\hline 01/08/98 & 200.7 & 200.7 & 200.9 & 200.7 & 200.9 & 200.7 & 200.9 & 200.7 & 200.7 & 200.7 & 200.7 & 200.7 & 200.7 & 415.2 \\
\hline 02/06/98 & 200.7 & 200.7 & 200.9 & 200.7 & 200.9 & 200.7 & 200.9 & 200.7 & 200.7 & 200.7 & 200.7 & 200.7 & 200.7 & 415.2 \\
\hline 03/04/98 & 200.7 & 200.7 & 200.9 & 200.7 & 200.9 & 200.7 & 200.9 & 200.7 & 200.7 & 200.7 & 200.7 & 200.7 & 200.7 & 415.2 \\
\hline 04/01/98 & 200.7 & 200.8 & 200.8 & 200.8 & 200.8 & 200.7 & 200.8 & 200.8 & 200.8 & -- & 200.8 & 200.8 & 200.7 & 415.2 \\
\hline $04 / 13 / 98$ & 200.7 & 206.2 & 213.2 & 200.7 & 200.7 & 200.7 & 239.2 & 200.7 & 200.7 & 270.2 & 272.2 & 279.2 & 200.7 & 415.2 \\
\hline $04 / 27 / 98$ & 200.7 & 200.8 & 200.8 & 200.8 & 200.8 & 200.7 & 200.8 & 200.8 & 200.8 & -- & 200.8 & 200.8 & 200.7 & 415.2 \\
\hline 05/04/98 & 200.7 & 200.8 & 200.8 & 200.8 & 200.8 & 200.7 & 200.8 & 200.8 & 200.8 & -- & 200.8 & 200.8 & 200.7 & 415.2 \\
\hline $05 / 11 / 98$ & 200.7 & 200.8 & 200.8 & 200.8 & 200.8 & 200.7 & 200.8 & 200.8 & 200.8 & -- & 200.8 & 200.8 & 200.7 & 415.2 \\
\hline 05/18/98 & 200.7 & 200.8 & 200.8 & 200.8 & 200.8 & 200.7 & 200.8 & 200.8 & 200.8 & -- & 200.8 & 200.8 & 200.7 & 415.2 \\
\hline $05 / 26 / 98$ & 200.7 & 200.8 & 200.8 & 200.8 & 200.8 & 200.7 & 200.8 & 200.8 & 200.8 & -- & 200.8 & 200.8 & 200.7 & 415.2 \\
\hline 06/01/98 & 200.7 & 200.8 & 200.8 & 200.8 & 200.8 & 200.7 & 200.8 & 200.8 & 200.8 & -- & 200.8 & 200.8 & 200.7 & 415.2 \\
\hline 06/08/98 & 200.7 & 200.8 & 200.8 & 200.8 & 200.8 & 200.7 & 200.8 & 200.8 & 200.8 & -- & 200.8 & 200.8 & 200.7 & 415.2 \\
\hline 06/17/98 & 200.7 & 200.8 & 200.8 & 200.8 & 200.8 & 200.7 & 200.8 & 200.8 & 200.8 & -- & 200.8 & 200.8 & 200.7 & 415.2 \\
\hline $06 / 22 / 98$ & 200.7 & 200.8 & 200.8 & 200.8 & 200.8 & 200.7 & 200.8 & 200.8 & 200.8 & 200.7 & 200.8 & 200.8 & 200.7 & 415.2 \\
\hline 06/29/98 & 200.7 & 200.8 & 200.8 & 200.8 & 200.8 & 200.7 & 200.8 & 200.8 & 200.8 & 200.7 & 200.8 & 200.8 & 200.7 & 415.2 \\
\hline 07/06/98 & 200.7 & 200.8 & 200.8 & 200.8 & 200.8 & 200.7 & 200.8 & 200.8 & 200.8 & 200.7 & 200.8 & 200.8 & 200.7 & 415.2 \\
\hline $07 / 13 / 98$ & 200.7 & 200.8 & 200.8 & 200.8 & 200.8 & 200.7 & 200.8 & 200.8 & 200.8 & 200.7 & 200.8 & 200.8 & 200.7 & 415.2 \\
\hline 07/20/98 & 200.7 & 200.8 & 200.8 & 200.8 & 200.8 & 200.7 & 200.8 & 200.8 & 200.8 & 200.7 & 200.8 & 200.8 & 200.7 & 415.2 \\
\hline $07 / 27 / 98$ & 200.7 & 200.8 & 200.8 & 200.8 & 200.8 & 200.7 & 200.8 & 200.8 & 200.8 & 200.7 & 200.8 & 200.8 & 200.7 & 415.2 \\
\hline 08/03/98 & 200.7 & 200.8 & 200.8 & 200.8 & 200.8 & 200.7 & 200.8 & 200.8 & 200.8 & 200.7 & 200.8 & 200.8 & 200.7 & 415.2 \\
\hline 08/10/98 & 200.7 & 200.8 & 200.8 & 200.8 & 200.8 & 200.7 & 200.8 & 200.8 & 200.8 & 200.7 & 200.8 & 200.8 & 200.7 & 415.2 \\
\hline
\end{tabular}


Table A4. Summary of U.S. Environmental Protection Agency analytical methods used for analysis of unfiltered samples

[Analytical method numbers defined in table A2; --, no data]]

\begin{tabular}{|c|c|c|c|c|c|c|c|c|c|c|c|c|c|c|c|c|c|c|}
\hline \multirow[b]{2}{*}{$\begin{array}{c}\text { Sampling } \\
\text { date }\end{array}$} & \multicolumn{3}{|c|}{ Total nutrients } & \multicolumn{13}{|c|}{ Total recoverable metals } & \multirow{2}{*}{$\begin{array}{c}\text { Total } \\
\text { organic } \\
\text { carbon }\end{array}$} & \multirow{2}{*}{$\begin{array}{l}\text { Total } \\
\text { suspended } \\
\text { solids }\end{array}$} \\
\hline & Ammonia & $\begin{array}{c}\text { Nitrite } \\
\text { plus } \\
\text { nitrate }\end{array}$ & $\begin{array}{l}\text { Phos- } \\
\text { phorus }\end{array}$ & Al & As & Cd & $\mathrm{Cr}$ & $\mathrm{Cu}$ & $\mathrm{Fe}$ & $\mathrm{Pb}$ & Mn & $\mathrm{Ni}$ & Se & Ag & $\mathrm{TI}$ & $\mathrm{Zn}$ & & \\
\hline $08 / 14 / 97$ & 350.1 & 353.2 & $\mathrm{I}-4600-85$ & 200.7 & 200.9 & 200.9 & 200.9 & 200.9 & 200.7 & 200.9 & 200.7 & 200.7 & 200.9 & 200.9 & 200.9 & 200.7 & 415.1 & 160.2 \\
\hline 08/20/97 & 350.1 & 353.2 & I-4600-85 & 200.7 & 200.9 & 200.9 & 200.9 & 200.9 & 200.7 & 200.9 & 200.7 & 200.7 & 200.9 & 200.9 & 200.9 & 200.7 & 415.1 & 160.2 \\
\hline 08/27/97 & 350.1 & 353.2 & I-4600-85 & 200.7 & 200.9 & 200.9 & 200.9 & 200.9 & 200.7 & 200.9 & 200.7 & 200.7 & 200.9 & 200.9 & 200.9 & 200.7 & 415.1 & 160.2 \\
\hline 09/05/97 & 350.1 & 353.2 & I- $-4600-85$ & 200.7 & 200.7 & 200.9 & 200.7 & 200.9 & 200.7 & 200.9 & 200.7 & 200.7 & 200.7 & 200.7 & 200.7 & 200.7 & 415.1 & 160.2 \\
\hline 09/12/97 & 350.1 & 353.2 & I- $-4600-85$ & 200.7 & 200.7 & 200.9 & 200.7 & 200.9 & 200.7 & 200.9 & 200.7 & 200.7 & 200.7 & 200.7 & 200.7 & 200.7 & 415.1 & 160.2 \\
\hline 09/19/97 & 350.1 & 353.2 & I-4600-85 & 200.7 & 200.7 & 200.9 & 200.7 & 200.9 & 200.7 & 200.9 & 200.7 & 200.7 & 200.7 & 200.7 & 200.7 & 200.7 & 415.1 & 160.2 \\
\hline 09/24/97 & 350.1 & 353.2 & I- $-4600-85$ & 200.7 & 200.7 & 200.9 & 200.7 & 200.9 & 200.7 & 200.9 & 200.7 & 200.7 & 200.7 & 200.7 & 200.7 & 200.7 & 415.1 & 160.2 \\
\hline 09/30/97 & 350.1 & 353.2 & I- $-4600-85$ & 200.7 & 200.7 & 200.9 & 200.7 & 200.9 & 200.7 & 200.9 & 200.7 & 200.7 & 200.7 & 200.7 & 200.7 & 200.7 & 415.1 & 160.2 \\
\hline 10/10/97 & 350.1 & 353.2 & I- $-4600-85$ & 200.7 & 200.7 & 200.9 & 200.7 & 200.9 & 200.7 & 200.9 & 200.7 & 200.7 & 200.7 & 200.7 & 200.7 & 200.7 & 415.1 & 160.2 \\
\hline $10 / 23 / 97$ & 350.1 & 353.2 & I-4600-85 & 200.7 & 200.7 & 200.9 & 200.7 & 200.9 & 200.7 & 200.9 & 200.7 & 200.7 & 200.7 & 200.7 & 200.7 & 200.7 & 415.1 & 160.2 \\
\hline $11 / 06 / 97$ & 350.1 & 353.2 & I- $-4600-85$ & 200.7 & 200.7 & 200.9 & 200.7 & 200.9 & 200.7 & 200.9 & 200.7 & 200.7 & 200.7 & 200.7 & 200.7 & 200.7 & 415.1 & 160.2 \\
\hline $12 / 04 / 97$ & 350.1 & 353.2 & I-4600-85 & 200.7 & 200.7 & 200.9 & 200.7 & 200.9 & 200.7 & 200.9 & 200.7 & 200.7 & 200.7 & 200.7 & 200.7 & 200.7 & 415.1 & 160.2 \\
\hline 01/08/98 & 350.1 & 353.2 & I-4600-85 & 200.7 & 200.7 & 200.9 & 200.7 & 200.9 & 200.7 & 200.9 & 200.7 & 200.7 & 200.7 & 200.7 & 200.7 & 200.7 & 415.1 & 160.2 \\
\hline 02/06/98 & 350.1 & 353.2 & I- $-4600-85$ & 200.7 & 200.7 & 200.9 & 200.7 & 200.9 & 200.7 & 200.9 & 200.7 & 200.7 & 200.7 & 200.7 & 200.7 & 200.7 & 415.1 & 160.2 \\
\hline 03/04/98 & 350.1 & 353.2 & I-4600-85 & 200.7 & 200.7 & 200.9 & 200.7 & 200.9 & 200.7 & 200.9 & 200.7 & 200.7 & 200.7 & 200.7 & 200.7 & 200.7 & 415.1 & 160.2 \\
\hline 04/01/98 & 350.1 & 353.2 & I- $-4600-85$ & 200.7 & 200.8 & 200.8 & 200.8 & 200.8 & 200.7 & 200.8 & 200.8 & 200.8 & -- & 200.8 & 200.8 & 200.7 & 415.1 & 160.2 \\
\hline 04/13/98 & 350.1 & 353.2 & I- $-4600-85$ & 200.7 & 206.2 & 213.2 & 200.7 & 200.7 & 200.7 & 239.2 & 200.7 & 200.7 & 270.2 & 272.2 & 279.2 & 200.7 & 415.1 & 160.2 \\
\hline 04/27/98 & 350.1 & 353.2 & I- $-4600-85$ & 200.7 & 200.8 & 200.8 & 200.8 & 200.8 & 200.7 & 200.8 & 200.8 & 200.8 & -- & 200.8 & 200.8 & 200.7 & 415.1 & 160.2 \\
\hline 05/04/98 & 350.1 & 353.2 & I- $-4600-85$ & 200.7 & 200.8 & 200.8 & 200.8 & 200.8 & 200.7 & 200.8 & 200.8 & 200.8 & -- & 200.8 & 200.8 & 200.7 & 415.1 & 160.2 \\
\hline 05/11/98 & 350.1 & 353.2 & I- $-4600-85$ & 200.7 & 200.8 & 200.8 & 200.8 & 200.8 & 200.7 & 200.8 & 200.8 & 200.8 & -- & 200.8 & 200.8 & 200.7 & 415.1 & 160.2 \\
\hline 05/18/98 & 350.1 & 353.2 & I- $-4600-85$ & 200.7 & 200.8 & 200.8 & 200.8 & 200.8 & 200.7 & 200.8 & 200.8 & 200.8 & -- & 200.8 & 200.8 & 200.7 & 415.1 & 160.2 \\
\hline 05/26/98 & 350.1 & 353.2 & I-4600-85 & 200.7 & 200.8 & 200.8 & 200.8 & 200.8 & 200.7 & 200.8 & 200.8 & 200.8 & -- & 200.8 & 200.8 & 200.7 & 415.1 & 160.2 \\
\hline 06/01/98 & 350.1 & 353.2 & I- $-4600-85$ & 200.7 & 200.8 & 200.8 & 200.8 & 200.8 & 200.7 & 200.8 & 200.8 & 200.8 & -- & 200.8 & 200.8 & 200.7 & 415.1 & 160.2 \\
\hline 06/08/98 & 350.1 & 353.2 & I-4600-85 & 200.7 & 200.8 & 200.8 & 200.8 & 200.8 & 200.7 & 200.8 & 200.8 & 200.8 & -- & 200.8 & 200.8 & 200.7 & 415.1 & 160.2 \\
\hline 06/17/98 & 350.1 & 353.2 & I- $-4600-85$ & 200.7 & 200.8 & 200.8 & 200.8 & 200.8 & 200.7 & 200.8 & 200.8 & 200.8 & -- & 200.8 & 200.8 & 200.7 & 415.1 & 160.2 \\
\hline 06/22/98 & 350.1 & 353.2 & I-4600-85 & 200.7 & 200.8 & 200.8 & 200.8 & 200.8 & 200.7 & 200.8 & 200.8 & 200.8 & 200.7 & 200.8 & 200.8 & 200.7 & 415.1 & 160.2 \\
\hline 06/29/98 & 350.1 & 353.2 & I- $-4600-85$ & 200.7 & 200.8 & 200.8 & 200.8 & 200.8 & 200.7 & 200.8 & 200.8 & 200.8 & 200.7 & 200.8 & 200.8 & 200.7 & 415.1 & 160.2 \\
\hline 07/06/98 & 350.1 & 353.2 & I- $-4600-85$ & 200.7 & 200.8 & 200.8 & 200.8 & 200.8 & 200.7 & 200.8 & 200.8 & 200.8 & 200.7 & 200.8 & 200.8 & 200.7 & 415.1 & 160.2 \\
\hline 07/13/98 & 350.1 & 353.2 & I-4600-85 & 200.7 & 200.8 & 200.8 & 200.8 & 200.8 & 200.7 & 200.8 & 200.8 & 200.8 & 200.7 & 200.8 & 200.8 & 200.7 & 415.1 & 160.2 \\
\hline 07/20/98 & 350.1 & 353.2 & I- $-4600-85$ & 200.7 & 200.8 & 200.8 & 200.8 & 200.8 & 200.7 & 200.8 & 200.8 & 200.8 & 200.7 & 200.8 & 200.8 & 200.7 & 415.1 & 160.2 \\
\hline 07/27/98 & 350.1 & 353.2 & I- $-4600-85$ & 200.7 & 200.8 & 200.8 & 200.8 & 200.8 & 200.7 & 200.8 & 200.8 & 200.8 & 200.7 & 200.8 & 200.8 & 200.7 & 415.1 & 160.2 \\
\hline 08/03/98 & 350.1 & 353.2 & I- $-4600-85$ & 200.7 & 200.8 & 200.8 & 200.8 & 200.8 & 200.7 & 200.8 & 200.8 & 200.8 & 200.7 & 200.8 & 200.8 & 200.7 & 415.1 & 160.2 \\
\hline 08/10/98 & 350.1 & 353.2 & I- $4600-85$ & 200.7 & 200.8 & 200.8 & 200.8 & 200.8 & 200.7 & 200.8 & 200.8 & 200.8 & 200.7 & 200.8 & 200.8 & 200.7 & 415.1 & 160.2 \\
\hline
\end{tabular}


Table A5. Results of water-quality analyses for duplicate total recoverable metal samples collected from Georgetown Lake inflow and outflow, 1997-98 $[\mu \mathrm{g} / \mathrm{L}$, micrograms per liter; --, no data; <, less than; see table 7 for results of primary inflow samples and table 8 for results of primary outflow samples]

\begin{tabular}{|c|c|c|c|c|c|c|c|c|c|c|c|c|c|c|c|c|c|c|c|c|c|c|c|c|c|c|}
\hline \multirow{3}{*}{$\begin{array}{l}\text { Sampling } \\
\text { date }\end{array}$} & \multicolumn{26}{|c|}{$\begin{array}{c}\text { Total recoverable metals } \\
(\mu \mathrm{g} / \mathrm{L})\end{array}$} \\
\hline & \multicolumn{13}{|c|}{ Georgetown Lake inflow, site SW24U } & \multicolumn{13}{|c|}{ Georgetown Lake outflow, site SW24L } \\
\hline & $\mathbf{A l}$ & As & Cd & $\mathrm{Cr}$ & $\mathrm{Cu}$ & $\mathrm{Fe}$ & $\mathrm{Pb}$ & Mn & $\mathrm{Ni}$ & $\mathrm{Se}$ & $\mathbf{A g}$ & $\mathrm{TI}$ & $\mathrm{Zn}$ & Al & As & Cd & $\mathrm{Cr}$ & $\mathrm{Cu}$ & $\mathrm{Fe}$ & $\mathrm{Pb}$ & Mn & $\mathrm{Ni}$ & Se & $\mathbf{A g}$ & $\mathrm{TI}$ & $\mathrm{Zr}$ \\
\hline $08 / 14 / 97$ & -- & -- & -- & -- & -- & -- & -- & -- & -- & -- & -- & -- & -- & 52 & $<1$ & 0.7 & $<0.8$ & 1.8 & 130 & 1.8 & 24 & $<11$ & $<1$ & $<0.2$ & $<1$ & 154 \\
\hline 08/20/97 & 58 & $<1$ & 0.8 & $<0.8$ & 1.8 & 116 & 1.7 & 18 & $<11$ & $<1$ & $<0.2$ & $<1$ & 189 & -- & -- & -- & -- & -- & -- & -- & -- & -- & -- & -- & -- & - \\
\hline $08 / 27 / 97$ & -- & -- & -- & -- & -- & -- & -- & -- & -- & -- & -- & -- & -- & 127 & $<1$ & 0.7 & $<0.8$ & 2.0 & 377 & 4.0 & 36 & $<11$ & $<1$ & $<0.2$ & $<1$ & 199 \\
\hline $09 / 05 / 97$ & 67 & $<50$ & $<0.5$ & $<4$ & 1.0 & 145 & 2.0 & 25 & $<11$ & $<40$ & $<6$ & $<50$ & 228 & -- & -- & -- & -- & -- & -- & -- & -- & -- & -- & -- & -- & - \\
\hline $09 / 12 / 97$ & -- & -- & -- & -- & -- & -- & -- & -- & -- & -- & -- & -- & -- & $<40$ & $<50$ & $<0.5$ & $<4$ & 0.9 & 203 & 1.9 & 37 & $<11$ & $<40$ & $<6$ & $<50$ & 224 \\
\hline 09/19/97 & $<40$ & $<50$ & 0.6 & $<4$ & 1.3 & 103 & 1.0 & 23 & $<11$ & $<40$ & $<6$ & $<50$ & 279 & -- & -- & -- & -- & -- & -- & -- & -- & -- & -- & -- & -- & - \\
\hline $09 / 24 / 97$ & -- & -- & -- & -- & -- & -- & -- & -- & -- & -- & -- & -- & -- & $<40$ & $<50$ & $<0.5$ & $<4$ & 1.9 & 226 & 2.4 & 36 & $<11$ & $<40$ & $<6$ & $<50$ & 248 \\
\hline 09/30/97 & -- & -- & -- & -- & -- & -- & -- & -- & -- & -- & -- & -- & -- & $<40$ & $<50$ & $<0.5$ & $<4$ & 0.8 & 216 & 1.8 & 32 & $<11$ & $<40$ & $<6$ & $<50$ & 250 \\
\hline $10 / 10 / 97$ & -- & -- & -- & -- & -- & -- & -- & -- & -- & -- & -- & -- & -- & $<40$ & $<50$ & $<0.5$ & $<4$ & 0.9 & 250 & 4.4 & 43 & $<11$ & $<40$ & $<6$ & $<50$ & 271 \\
\hline $10 / 23 / 97$ & $<40$ & $<50$ & 1.0 & 4 & 0.8 & 87 & 2.0 & 29 & $<11$ & $<40$ & $<6$ & $<50$ & 428 & -- & -- & -- & -- & -- & -- & -- & -- & -- & -- & -- & -- & - \\
\hline $11 / 06 / 97$ & -- & -- & -- & -- & -- & -- & -- & -- & -- & -- & -- & -- & -- & $<40$ & $<50$ & 1.0 & $<4$ & 0.9 & 212 & 2.4 & 32 & $<11$ & $<40$ & $<6$ & $<50$ & 377 \\
\hline $12 / 04 / 97$ & 398 & $<50$ & 2.3 & $<4$ & 2.9 & 661 & 26 & 64 & $<11$ & $<40$ & $<6$ & $<50$ & 586 & -- & -- & -- & -- & -- & -- & -- & -- & -- & -- & -- & -- & - \\
\hline $01 / 08 / 98$ & $<40$ & $<50$ & 1.2 & 5 & $<0.8$ & 84 & 1.2 & 24 & $<11$ & $<40$ & $<6$ & $<50$ & 534 & -- & -- & -- & -- & -- & -- & -- & -- & -- & -- & -- & -- & - \\
\hline $02 / 06 / 98$ & $<40$ & $<50$ & 1.7 & $<4$ & $<0.8$ & 53 & 1.3 & 21 & $<11$ & $<40$ & $<6$ & $<50$ & 518 & -- & -- & -- & -- & -- & -- & -- & -- & -- & -- & -- & -- & - \\
\hline 03/04/98 & $<40$ & $<50$ & 1.4 & $<4$ & $<0.8$ & 60 & 1.2 & 21 & $<11$ & $<40$ & $<6$ & $<50$ & 530 & -- & -- & -- & -- & -- & -- & -- & -- & -- & -- & -- & -- & - \\
\hline $04 / 01 / 98$ & -- & -- & -- & -- & -- & -- & -- & -- & -- & -- & -- & -- & -- & 58 & $<5$ & 1.1 & $<5$ & $<1$ & 270 & 3 & 48 & $<5$ & -- & $<0.1$ & $<1.0$ & 450 \\
\hline $04 / 13 / 98$ & 47.8 & $<1$ & 1.8 & $<5$ & $<2$ & 71 & $<1$ & 23 & $<10$ & -- & $<0.2$ & $<1$ & 594 & -- & -- & -- & -- & -- & -- & -- & -- & -- & -- & -- & -- & - \\
\hline $04 / 27 / 98$ & -- & -- & -- & -- & -- & -- & -- & -- & -- & -- & -- & -- & -- & 60 & $<5$ & 1.0 & $<5$ & $<1$ & 180 & 2 & 34 & $<5$ & & $<0.1$ & $<1.0$ & 430 \\
\hline $05 / 04 / 98$ & 140 & $<5$ & 1.9 & $<5$ & 2 & 290 & 3 & 34 & $<5$ & -- & $<0.1$ & $<1.0$ & 580 & -- & -- & -- & -- & -- & -- & -- & -- & -- & -- & -- & -- & - \\
\hline $05 / 11 / 98$ & -- & -- & -- & -- & -- & -- & -- & -- & -- & -- & -- & -- & -- & 70 & $<5$ & 1.2 & $<5$ & 2 & 210 & 2 & 31 & $<5$ & & $<0.1$ & $<1.0$ & 470 \\
\hline 05/18/98 & 130 & $<5$ & 1.0 & $<5$ & 2 & 260 & 2 & 22 & $<5$ & -- & $<0.1$ & $<1.0$ & 320 & -- & -- & -- & -- & -- & -- & -- & -- & -- & -- & -- & -- & - \\
\hline $05 / 26 / 98$ & -- & -- & -- & -- & -- & -- & -- & -- & -- & -- & -- & -- & -- & 80 & $<5$ & 0.9 & $<5$ & 4 & 150 & 4 & 29 & $<5$ & & $<0.1$ & $<1.0$ & 240 \\
\hline $06 / 01 / 98$ & 160 & $<5$ & 0.6 & $<5$ & 3 & 240 & 6 & 23 & $<5$ & -- & $<0.1$ & $<1.0$ & 170 & -- & -- & -- & -- & -- & -- & -- & -- & -- & -- & -- & -- & - \\
\hline $06 / 08 / 98$ & -- & -- & -- & -- & -- & -- & -- & -- & -- & -- & -- & -- & -- & 60 & $<5$ & 0.6 & $<5$ & 1 & 100 & 1 & 21 & $<5$ & & $<0.1$ & $<1.0$ & 160 \\
\hline $06 / 17 / 98$ & $<100$ & $<5$ & 0.4 & $<5$ & $<1$ & 120 & 1 & 11 & $<5$ & $<5$ & $<0.1$ & $<1$ & 160 & -- & -- & -- & -- & -- & -- & -- & -- & -- & -- & -- & -- & - \\
\hline $06 / 22 / 98$ & -- & -- & -- & -- & -- & -- & -- & -- & -- & -- & -- & -- & -- & 70 & $<5$ & 0.4 & $<5$ & $<1$ & 110 & $<1$ & 13 & $<5$ & $<5$ & $<0.1$ & $<1$ & 130 \\
\hline $06 / 29 / 98$ & $<100$ & $<5$ & 0.4 & $<5$ & 1 & 180 & 2 & 12 & $<5$ & $<5$ & $<0.1$ & $<1$ & 110 & -- & -- & -- & -- & -- & -- & -- & -- & -- & -- & -- & -- & - \\
\hline $07 / 06 / 98$ & -- & -- & -- & -- & -- & -- & -- & -- & -- & -- & -- & -- & -- & $<100$ & $<5$ & 0.3 & $<5$ & $<1$ & 90 & $<1$ & 14 & $<5$ & $<5$ & $<0.1$ & $<1$ & 110 \\
\hline $07 / 13 / 98$ & $<45$ & $<5$ & 0.4 & $<5$ & $<1$ & 120 & 3 & 14 & $<5$ & $<5$ & $<0.1$ & $<1$ & 120 & -- & -- & -- & -- & -- & -- & -- & -- & -- & -- & -- & -- & - \\
\hline 07/20/98 & -- & -- & -- & -- & -- & -- & -- & -- & -- & -- & -- & -- & -- & $<45$ & $<5$ & 0.4 & $<5$ & $<1$ & 100 & 1 & 20 & $<5$ & $<5$ & $<0.1$ & $<1$ & 130 \\
\hline $07 / 27 / 98$ & -- & -- & -- & -- & -- & -- & -- & -- & -- & -- & -- & -- & -- & 240 & $<5$ & 0.4 & $<5$ & 2 & 460 & 7 & 39 & $<5$ & $<5$ & $<0.1$ & $<1$ & 140 \\
\hline 08/03/98 & 59 & $<5$ & 0.4 & $<5$ & 1 & 130 & 1 & 16 & $<5$ & $<5$ & $<0.1$ & $<1$ & 150 & -- & -- & -- & -- & -- & -- & -- & -- & -- & -- & -- & -- & - \\
\hline 08/10/98 & -- & -- & -- & -- & -- & -- & -- & -- & -- & -- & -- & -- & -- & 140 & $<5$ & 0.4 & $<5$ & 2 & 330 & 7 & 35 & $<5$ & $<5$ & $<0.1$ & $<1$ & 190 \\
\hline
\end{tabular}


Table A6. Results of analyses of water-quality blanks for equipment, filter, and preservatives

[ $\mu \mathrm{g} / \mathrm{L}$, micrograms per liter; TOC, total organic carbon; mg/L, milligrams per liter; <, less than; --, no data; highlighting indicates concentration above laboratory reporting limit]

\begin{tabular}{|c|c|c|c|c|c|c|c|c|c|c|c|c|c|c|}
\hline \multirow[t]{2}{*}{$\begin{array}{l}\text { Sampling } \\
\text { date }\end{array}$} & \multicolumn{4}{|c|}{$\begin{array}{c}\text { Equipment blank, } \\
\text { total recoverable metals } \\
(\mu \mathrm{g} / \mathrm{L})\end{array}$} & \multicolumn{4}{|c|}{$\begin{array}{c}\text { Filter blank, } \\
\text { total recoverable metals } \\
(\mu \mathrm{g} / \mathrm{L})\end{array}$} & \multicolumn{4}{|c|}{$\begin{array}{c}\text { Preservative blank, } \\
\text { total recoverable metals } \\
(\mu \mathrm{g} / \mathrm{L})\end{array}$} & $\begin{array}{l}\text { Equipment blank, } \\
\text { TOC/nutrients } \\
\text { (mg/L) }\end{array}$ & $\begin{array}{c}\text { Preservative blank, } \\
\text { TOC/nutrients } \\
\text { (mg/L) }\end{array}$ \\
\hline & Cd & $\mathrm{Fe}$ & Mn & $\mathrm{Zn}$ & Cd & $\mathrm{Fe}$ & Mn & Zn & Cd & $\mathbf{F e}$ & Mn & $\mathbf{Z n}$ & Total ph & sphorus \\
\hline $08 / 14 / 97$ & $<0.5$ & $<5$ & $<1$ & 4 & $<0.5$ & $<5$ & $<1$ & 7 & $<0.5$ & $<5$ & $<1$ & $<4$ & $<0.02$ & $<0.02$ \\
\hline 08/20/97 & $<0.5$ & $<5$ & 1 & 9 & $<0.5$ & $<5$ & 1 & 5 & $<0.5$ & $<5$ & 1 & $<4$ & $<0.02$ & $<0.02$ \\
\hline 08/27/97 & $<0.5$ & $<5$ & $<1$ & $<4$ & $<0.5$ & $<5$ & $<1$ & $<4$ & $<0.5$ & $<5$ & $<1$ & $<4$ & $<0.02$ & $<0.02$ \\
\hline 09/05/97 & $<0.5$ & $<5$ & $<1$ & 4 & $<0.5$ & $<5$ & $<1$ & $<4$ & $<0.5$ & $<5$ & $<1$ & $<4$ & $<0.02$ & $<0.02$ \\
\hline 09/12/97 & $<0.5$ & $<5$ & $<1$ & $<4$ & $<0.5$ & $<5$ & $<1$ & $<4$ & $<0.5$ & $<5$ & $<1$ & $<4$ & $<0.02$ & $<0.02$ \\
\hline 09/19/97 & $<0.5$ & $<5$ & $<1$ & $<4$ & $<0.5$ & $<5$ & 1 & $<4$ & $<0.5$ & $<5$ & $<1$ & $<4$ & $<0.02$ & $<0.02$ \\
\hline 09/24/97 & $<0.5$ & $<5$ & $<1$ & $<4$ & $<0.5$ & $<5$ & $<1$ & $<4$ & $<0.5$ & $<5$ & $<1$ & $<4$ & $<0.02$ & $<0.02$ \\
\hline 09/30/97 & $<0.5$ & $<5$ & $<1$ & $<4$ & $<0.5$ & $<5$ & $<1$ & $<4$ & $<0.5$ & $<5$ & $<1$ & $<4$ & 0.03 & 0.03 \\
\hline $10 / 10 / 97$ & $<0.5$ & $<5$ & $<1$ & $<4$ & $<0.5$ & $<5$ & $<1$ & $<4$ & $<0.5$ & $<5$ & $<1$ & $<4$ & $<0.02$ & $<0.02$ \\
\hline $10 / 23 / 97$ & $<0.5$ & $<5$ & $<1$ & $<4$ & $<0.5$ & $<5$ & $<1$ & $<4$ & $<0.5$ & $<5$ & $<1$ & $<4$ & $<0.02$ & $<0.02$ \\
\hline $11 / 06 / 97$ & $<0.5$ & $<5$ & $<1$ & $<4$ & $<0.5$ & $<5$ & $<1$ & $<4$ & $<0.5$ & $<5$ & $<1$ & $<4$ & $<0.02$ & $<0.02$ \\
\hline $12 / 04 / 97$ & $<0.5$ & $<5$ & $<1$ & $<4$ & $<0.5$ & $<5$ & $<1$ & $<4$ & $<0.5$ & $<5$ & $<1$ & $<4$ & $<0.02$ & $<0.02$ \\
\hline 01/08/98 & $<0.5$ & $<5$ & $<1$ & $<4$ & $<0.5$ & $<5$ & $<1$ & $<4$ & $<0.5$ & $<5$ & $<1$ & $<4$ & $<0.02$ & $<0.02$ \\
\hline 02/06/98 & $<0.5$ & $<5$ & $<1$ & $<4$ & $<0.5$ & $<5$ & $<1$ & $<4$ & $<0.5$ & $<5$ & $<1$ & $<4$ & $<0.02$ & $<0.02$ \\
\hline 03/04/98 & $<0.5$ & $<5$ & $<1$ & $<4$ & $<0.5$ & $<5$ & 1 & $<4$ & $<0.5$ & $<5$ & $<1$ & $<4$ & $<0.02$ & $<0.02$ \\
\hline 04/01/98 & 0.2 & 20 & $<1$ & $<5$ & 0.3 & 20 & $<1$ & $<5$ & 0.2 & 20 & $<1$ & $<5$ & $<0.01$ & 0.01 \\
\hline $04 / 13 / 98$ & $<0.5$ & $<5$ & $<1$ & $<4$ & $<0.5$ & $<5$ & $<1$ & $<4$ & $<0.5$ & $<5$ & $<1$ & $<4$ & $<0.02$ & $<0.02$ \\
\hline $04 / 27 / 98$ & $<0.1$ & $<10$ & $<1$ & $<5$ & $<0.5$ & $<10$ & $<1$ & $<5$ & $<0.1$ & $<10$ & $<1$ & $<5$ & $<0.01$ & $<0.01$ \\
\hline 05/04/98 & -- & -- & -- & -- & -- & -- & -- & -- & -- & -- & -- & -- & -- & -- \\
\hline 05/11/98 & $<0.1$ & $<10$ & $<1$ & $<5$ & $<0.5$ & $<10$ & $<1$ & $<5$ & $<0.1$ & $<10$ & $<1$ & $<5$ & 0.02 & $<0.01$ \\
\hline 05/18/98 & $<0.1$ & $<10$ & $<1$ & $<5$ & $<0.5$ & $<10$ & $<1$ & $<5$ & $<0.1$ & $<10$ & $<1$ & $<5$ & $<0.01$ & $<0.01$ \\
\hline 05/26/98 & $<0.1$ & $<10$ & $<1$ & $<5$ & $<0.5$ & $<10$ & $<1$ & $<5$ & $<0.1$ & $<10$ & $<1$ & $<5$ & $<0.01$ & $<0.01$ \\
\hline 06/01/98 & $<0.1$ & $<10$ & $<1$ & $<5$ & $<0.5$ & $<10$ & $<1$ & $<5$ & $<0.1$ & $<10$ & $<1$ & $<5$ & $<0.01$ & $<0.01$ \\
\hline 06/08/98 & $<0.1$ & $<10$ & $<1$ & $<5$ & $<0.5$ & $<10$ & $<1$ & $<5$ & $<0.1$ & $<10$ & $<1$ & $<5$ & $<0.01$ & $<0.01$ \\
\hline 06/17/98 & $<0.1$ & $<10$ & $<1$ & $<5$ & $<0.5$ & $<10$ & $<1$ & $<5$ & $<0.1$ & $<10$ & $<1$ & $<5$ & $<0.01$ & $<0.01$ \\
\hline $06 / 22 / 98$ & $<0.1$ & $<10$ & $<1$ & $<5$ & $<0.5$ & 10 & $<1$ & $<5$ & $<0.1$ & $<10$ & $<1$ & $<5$ & $<0.01$ & $<0.01$ \\
\hline 06/29/98 & $<0.1$ & $<10$ & $<1$ & $<5$ & $<0.5$ & 30 & $<1$ & $<5$ & $<0.1$ & $<10$ & $<1$ & $<5$ & $<0.01$ & $<0.01$ \\
\hline 07/06/98 & $<0.1$ & $<10$ & $<1$ & 6 & $<0.5$ & 20 & $<1$ & 6 & $<0.1$ & $<10$ & $<1$ & 7 & $<0.01$ & $<0.01$ \\
\hline 07/13/98 & $<0.1$ & $<10$ & $<1$ & $<5$ & $<0.5$ & $<10$ & $<1$ & $<5$ & $<0.1$ & $<10$ & $<1$ & 5 & $<0.01$ & $<0.01$ \\
\hline 07/20/98 & $<0.1$ & $<10$ & $<1$ & $<5$ & $<0.5$ & $<10$ & $<1$ & $<5$ & $<0.1$ & $<10$ & $<1$ & $<5$ & $<0.01$ & $<0.01$ \\
\hline 07/27/98 & $<0.1$ & $<10$ & $<1$ & $<5$ & $<0.5$ & $<10$ & $<1$ & $<5$ & $<0.1$ & $<10$ & $<1$ & $<5$ & $<0.01$ & $<0.01$ \\
\hline 08/03/98 & $<0.1$ & $<10$ & $<1$ & $<5$ & $<0.5$ & $<10$ & $<1$ & $<5$ & $<0.1$ & $<10$ & $<1$ & $<5$ & $<0.01$ & $<0.01$ \\
\hline 08/10/98 & $<0.1$ & $<10$ & $<1$ & $<5$ & $<0.5$ & $<10$ & $<1$ & $<5$ & $<0.1$ & $<10$ & $<1$ & $<5$ & $<0.01$ & $<0.01$ \\
\hline
\end{tabular}


Table A7. Results of analyses of U.S. Geological Survey standard-reference samples

$[\mathrm{mg} / \mathrm{L}$, milligrams per liter; $\mu \mathrm{g} / \mathrm{L}$, micrograms per liter; <, less than; --, rating not generated for concentration below reporting limit]

\begin{tabular}{|c|c|c|c|c|c|}
\hline \multirow{2}{*}{$\begin{array}{l}\text { Analyte } \\
\text { and units }\end{array}$} & \multirow{2}{*}{$\begin{array}{l}\text { Most probable } \\
\text { concentration }\end{array}$} & \multicolumn{2}{|c|}{ Analysis on $05 / 26 / 98$} & \multicolumn{2}{|c|}{ Analysis on $07 / 20 / 98$} \\
\hline & & $\begin{array}{c}\text { Reported } \\
\text { concentration }\end{array}$ & Rating $^{2}$ & $\begin{array}{c}\text { Reported } \\
\text { concentration }\end{array}$ & Rating $^{2}$ \\
\hline Alkalinity, $\mathrm{mg} / \mathrm{L}$ as $\mathrm{CaCO}_{3}$ & 41.1 & 38 & 1 & 32 & 0 \\
\hline Chloride, $\mathrm{mg} / \mathrm{L}$ & 33.4 & 38 & 1 & 45 & 0 \\
\hline Fluoride, mg/L & 0.720 & 0.66 & 2 & 0.74 & 4 \\
\hline Sulfate, $\mathrm{mg} / \mathrm{L}$ as $\mathrm{SO}_{4}$ & 28.0 & 29 & 3 & 32 & 0 \\
\hline $\mathrm{pH}$, standard unit & 7.81 & 7.9 & 4 & 7.7 & 3 \\
\hline Silica, dissolved, $\mathrm{mg} / \mathrm{L}$ as $\mathrm{SiO}_{2}$ & 4.18 & 3.8 & 1 & 3.9 & 2 \\
\hline Aluminum, dissolved, $\mu \mathrm{g} / \mathrm{L}$ & 75.4 & 95 & 1 & 52 & 0 \\
\hline Arsenic, dissolved, $\mu \mathrm{g} / \mathrm{L}$ & 7.50 & 7 & 3 & 8 & 3 \\
\hline Cadmium, dissolved, $\mu \mathrm{g} / \mathrm{L}$ & 8.20 & 8.7 & 3 & 9.1 & 1 \\
\hline Calcium, dissolved, mg/L & 19.1 & 20 & 3 & 20 & 3 \\
\hline Chromium, dissolved, $\mu \mathrm{g} / \mathrm{L}$ & 15.4 & 14 & 3 & 14 & 3 \\
\hline Copper, dissolved, $\mu \mathrm{g} / \mathrm{L}$ & 18.0 & 17 & 3 & 18 & 4 \\
\hline Iron, dissolved, $\mu \mathrm{g} / \mathrm{L}$ & 4.3 & $<10$ & -- & $<10$ & -- \\
\hline Lead, dissolved, $\mu \mathrm{g} / \mathrm{L}$ & 5.7 & 5 & 3 & 5 & 3 \\
\hline Magnesium, dissolved, mg/L & 5.48 & 5.6 & 4 & 5.6 & 4 \\
\hline Manganese, dissolved, $\mu \mathrm{g} / \mathrm{L}$ & 20.0 & 10 & 0 & 7 & 0 \\
\hline Nickel, dissolved, $\mu \mathrm{g} / \mathrm{L}$ & 17.0 & 17 & 4 & 18 & 4 \\
\hline Potassium, dissolved, mg/L & 2.32 & 2 & 1 & 2 & 4 \\
\hline Selenium, dissolved, $\mu \mathrm{g} / \mathrm{L}$ & 8.4 & 11 & 0 & 10 & 2 \\
\hline Silver, dissolved, $\mu \mathrm{g} / \mathrm{L}$ & 5.91 & 5.6 & 4 & 5.7 & 4 \\
\hline Sodium, dissolved, mg/L & 33.0 & 35 & 1 & 33 & 4 \\
\hline Thallium, dissolved, $\mu \mathrm{g} / \mathrm{L}$ & 4.0 & 3 & 2 & 4 & 4 \\
\hline Zinc, dissolved, $\mu \mathrm{g} / \mathrm{L}$ & 218 & 250 & 0 & 250 & 0 \\
\hline
\end{tabular}

${ }^{1}$ Median value of concentrations reported by laboratories participating in the standard reference sample program (Farrar and Long, 1996, p. 1-10).

${ }^{2}$ Ratings are based on the absolute Z-value. Rating 4 is excellent (absolute Z-value 0.00 to 0.50 ), rating 3 is good (absolute Z-value 0.51 to 1.00 ), rating 2 is satisfactory (absolute Z-value 1.01 to 1.50), rating 1 is questionable (absolute Z-value 1.51 to 2.00), and rating 0 is poor (absolute Z-value greater than 2.00) (Farrar and Long, 1996). 